\title{
RESRAD-BUILD Verification
}

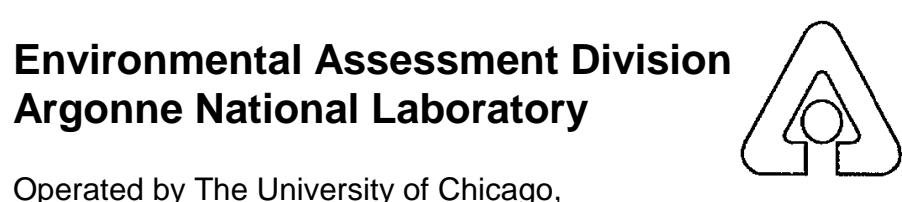

Operated by The University of Chicago, under Contract W-31-109-Eng-38, for the

\section{United States Department of Energy}


Argonne National Laboratory, with facilities in the states of Illinois and Idaho, is owned by the United States Government and operated by The University of Chicago under the provisions of a contract with the U.S. Department of Energy.

\title{
DISCLAIMER
}

This report was prepared as an account of work sponsored by an agency of the United States Government. Neither the United States Government nor any agency thereof, nor The University of Chicago, nor any of their employees or officers, makes any warranty, express or implied, or assumes any legal liability or responsibility for the accuracy, completeness, or usefulness of any information, apparatus, product, or process disclosed, or represents that its use would not infringe privately owned rights. Reference herein to any specific commercial product, process, or service by trade name, trademark, manufacturer, or otherwise does not necessarily constitute or imply its endorsement, recommendation, or favoring by the United States Government or any agency thereof. The views and opinions of document authors expressed herein do not necessarily state or reflect those of the United States Government or any agency thereof, Argonne National Laboratory, or The University of Chicago.

Available electronically at http://www.doe.gov/bridge

Available for a processing fee to U.S. Department of Energy and its contractors, in paper, from:

\author{
U.S. Department of Energy \\ Office of Scientific and Technical Information \\ P.O. Box 62 \\ Oak Ridge, TN 37831-0062 \\ phone: (865) 576-8401 \\ fax: (865) 576-5728 \\ email: reports@adonis.osti.gov
}




\section{RESRAD-BUILD Verification}

by S. Kamboj, C. Yu, B.M. Biwer, and T. Klett

Environmental Assessment Division

Argonne National Laboratory, 9700 South Cass Avenue, Argonne, Illinois 60439

October 2001

Work sponsored by U.S. Department of Energy, Assistant Secretary for Environment, Safety, and Health, Office of Environmental Policy and Guidance, Assistant Secretary for Environmental Management, Office of Site Closure 


\section{NOTICE}

This technical memorandum is an information product of Argonne's Environmental Assessment Division (EAD). It presents results of ongoing work or work that is more limited in scope and depth than that described in formal reports issued by $E A D$. This memorandum has undergone internal technical review and has been edited according to EAD's quality assurance requirements. In contrast to a formal technical report, this memorandum has not been externally peer reviewed.

For more information on the division's scientific and engineering activities, contact:

Director, Environmental Asessment Division

Argonne National Laboratory

Argonne, Illinois 60439

Telephone (630) 252-3107

email: ead@anl.gov

Publishing support services were provided by Argonne's Information and Publishing Division (for more information, see IPD's home page: http://www.ipd.anl.gov).

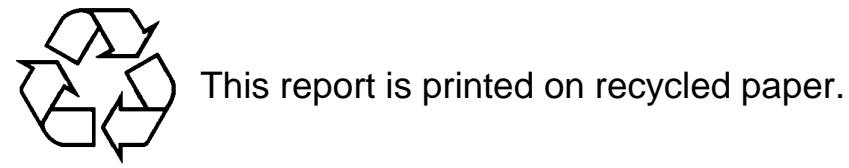




\section{CONTENTS}

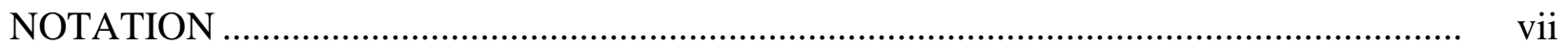

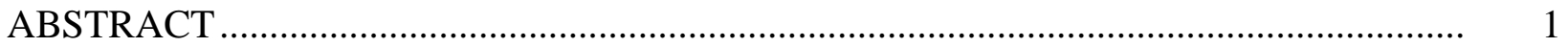

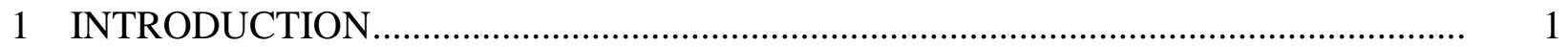

2 PARAMETER VERIFICATION ...................................................................... 5

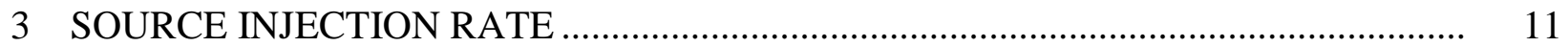

4 AIR CONCENTRATION AND PARTICULATE DEPOSITION ................................ 15

5 RADON PATHWAY MODEL ...................................................................... 25

5.1 Radon Injection Rate .............................................................................. 26

5.2 Radon Progeny Concentration ................................................................... 30

6 TRITIUM MODEL FOR VOLUME SOURCE ….................................................

$7 \quad$ EXTERNAL EXPOSURE MODEL ....................................................................... 45

8 DIFFERENT PATHWAY DOSES ................................................................. 53

8.1 Submersion Pathway ...................................................................................... 53

8.2 Inadvertent Ingestion Directly from the Source ............................................... 55

8.3 Inadvertent Ingestion of Deposited Materials ..................................................... 58

8.4 Dose from Inhalation of Airborne Radioactive Particulates .................................. 59

8.5 Dose from Inhalation of Aerosol Indoor Radon Progeny .................................... 63

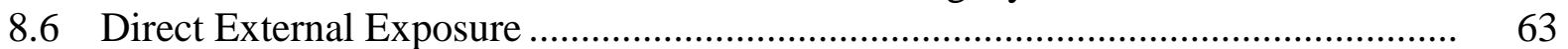

8.7 External Exposure to Deposited Materials .......................................................... 64

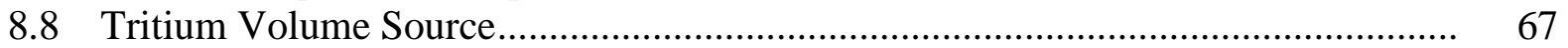

8.9 Total Dose at a Receptor Location ................................................................... 69

9 TIME DEPENDENCE IN DOSE CALCULATIONS............................................. 73

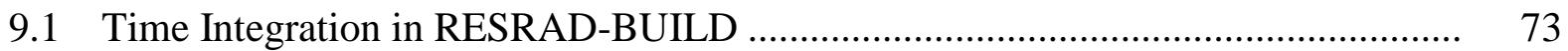

9.2 Time Dependence of Source Characteristics in Dose ........................................ 74

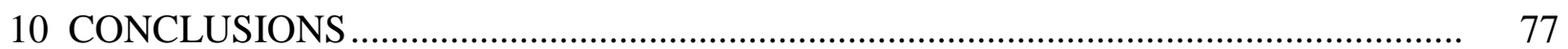

11 VERIFICATION LIMITATIONS AND SUGGESTIONS FOR IMPROVEMENT ........ 81

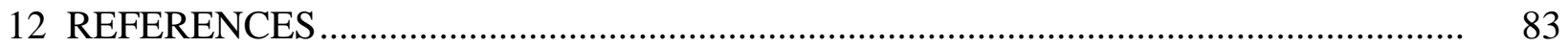




\section{CONTENTS (Cont.)}

APPENDIX: RESRAD-BUILD INPUT-OUTPUT TEST CASE FILES

AND DIAG.OUT AND SUMMARY REPORTS

\section{TABLES}

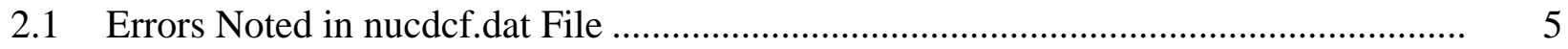

2.2 Parameters and Parameter Values Used in RESRAD-BUILD Verification .................... 7

2.3 Cases Used in RESRAD-BUILD Verification ............................................................ 9

3.1 Comparison of RESRAD-BUILD and Spreadsheet Values for Source Injection Rate

4.1 RESRAD-BUILD and Spreadsheet Air Concentration Values

for the One-Room Air Quality Model

4.2 RESRAD-BUILD and Spreadsheet Air Concentration Values for the Two-Room Air Quality Model.

5.1 RESRAD-BUILD and Spreadsheet Injection Rates for Ra-226 and Th-228

Point and Volume Sources for Three Sets of Input Parameters

5.2 RESRAD-BUILD and Spreadsheet Air Concentrations for Ra-226 and Th-228 and Their Progeny for Three Sets of Input Parameters

7.1 Point Source Dose Comparison between RESRAD-BUILD and MCNP

7.2 Line Source Dose Comparison between RESRAD-BUILD and MCNP …….............. 50

7.3 Area Source Dose Comparison between RESRAD-BUILD and MCNP ...................... $\quad 50$

7.4 Volume Source Dose Comparison between RESRAD-BUILD and MCNP ................. 51

7.5 Direct External Exposure Pathway Dose Comparison between RESRAD-BUILD and MCNP Using Default Parameters

8.1 RESRAD-BUILD and Spreadsheet Submersion Pathway Dose Values for Three Sets of Input Parameters 


\section{TABLES (Cont.)}

8.2 RESRAD-BUILD and Spreadsheet Direct Inadvertent Ingestion Pathway Dose Values for Three Sets of Input Parameters

8.3 RESRAD-BUILD and Spreadsheet Dose Values for the Inadvertent Ingestion of Deposited Material for Three Sets of Input Parameters

8.4 RESRAD-BUILD and Spreadsheet Inhalation Pathway Dose Values

for Three Sets of Input Parameters

8.5 RESRAD-BUILD and Spreadsheet Radon Inhalation Pathway Dose Values for Ra-226 and Th-228 Sources for Three Sets of Input Parameters

8.6 RESRAD-BUILD and Spreadsheet Direct External Exposure Pathway

Dose Values for Three Sets of Input Parameters.

8.7 RESRAD-BUILD and Spreadsheet Dose Values from the External Exposure of Deposited Material for Three Sets of Input Parameters

8.8 RESRAD-BUILD and Spreadsheet Inhalation and Ingestion Pathway Dose Values for the Tritium Volume Source for Three Sets of Input Parameters

8.9 Receptor Dose for Different Exposure Times for the Ra-228 Volume Source

9.1 Calculated Dose for the Ra-228 Volume Source with Default Parameters

9.2 Time Dependence of Source Emission Rate and Effect on Estimated Data

9.3 Calculated Radionuclide Concentrations at Different Times in the RESRAD-BUILD and RESRAD Codes for an Initial Parent Concentration of $1 \mathrm{pCi} / \mathrm{g}$

10.1 Conclusions on Types of Calculations Investigated

\section{FIGURES}

3.1 Source Injection Rate Calculations for Volume, Surface, Line, and Point Sources...... 14

4.1 Calculated Air Concentrations for Volume, Surface, Line, and Point Sources for the One-Room Air Quality Model 


\section{FIGURES (Cont.)}

4.2 Calculated Air Concentrations for the Volume Source for the Two-Room Air Quality Model.

4.3 Calculated Air Concentrations for Point, Line, and Surface Sources for the Two-Room Air Quality Model................................................................... 20

4.4 In-between Calculations for the Two-Room Air Quality Model................................ 21

4.5 Calculated Surface Concentration from Deposition ............................................. 24

5.1 Radon Flux Calculations for a Volume Source ................................................. 28

5.2 Injection Rates for Rn-222 and Rn-220 for a Point and Volume Source .................... 31

5.3 Air Concentrations for Ra-226 and Th-228 Progeny for a Point Source .................... 33

6.1 Tritium Model Intermediate Calculations for the Injection Rate from Vaporization and the Average Release Rate from the Tritium Volume Source from Volatization..... 42

8.1 Air Submersion Pathway Dose Calculations .................................................... 54

8.2 Inadvertent Ingestion Pathway Dose Directly from the Source ............................. 57

8.3 Inadvertent Ingestion Pathway Dose Directly from Materials Deposited on Surfaces .................................................................................. 60

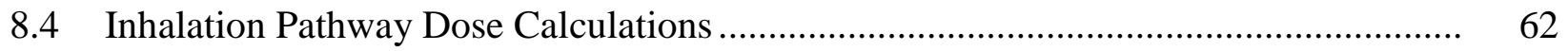

8.5 Radon Pathway Dose Calculations ................................................................ 65

8.6 Direct External Exposure Pathway Doses from a Volume and Surface Source of a Large Area.......................................................................... 66

8.7 External Exposure from Deposited Materials.................................................. 68

8.8 Inhalation and Ingestion Pathway Doses for a Tritium Volume Source for the Default Parameter Set

8.9 Estimated Dose with and without Time Integration .............................................. 


\section{NOTATION}

The following is a list of the acronyms, initialisms, and abbreviations (including units of measure) used in this document.

\section{ACRONYMS, INITIALISMS, AND ABBREVIATIONS}

$\begin{array}{ll}\text { DCF } & \text { dose conversion factor } \\ \text { FGR } & \text { Federal Guidance Report } \\ \text { G-P } & \text { geometric progression } \\ \text { HTO } & \text { tritiated water } \\ \text { MCNP } & \text { Monte Carlo N-particle } \\ \text { WL } & \text { working level } \\ \text { WLM } & \text { working level month }\end{array}$

\section{UNITS OF MEASURE}

$\begin{array}{ll}\text { atm } & \text { atmosphere(s) } \\ \mathrm{cm} & \text { centimeter(s) } \\ \mathrm{cm}^{2} & \text { square centimeter(s) } \\ \mathrm{cm}^{3} & \text { cubic centimeter(s) } \\ \mathrm{d} & \text { day(s) } \\ \mathrm{g} & \text { gram(s) } \\ \mathrm{h} & \text { hour(s) } \\ \mathrm{K} & \text { kelvin(s) } \\ \mathrm{kg} & \text { kilogram(s) } \\ \mathrm{m} & \text { meter(s) } \\ \mathrm{m} & \text { square meter(s) } \\ \mathrm{m}^{3} & \text { cubic meter(s) } \\ \mathrm{mol} & \text { mole(s) } \\ \mathrm{mrem} & \text { millirem(s) } \\ \mathrm{pCi} & \text { picocurie(s) } \\ \mathrm{s} & \text { second(s) } \\ \mathrm{yr} & \text { year(s) }\end{array}$




\title{
RESRAD-BUILD VERIFICATION
}

by

\author{
S. Kamboj, C. Yu, B.M. Biwer, and T. Klett
}

\begin{abstract}
The results generated by the RESRAD-BUILD code (version 3.0) were verified with hand or spreadsheet calculations using equations given in the RESRAD-BUILD manual for different pathways. For verification purposes, different radionuclides - H-3, C-14, Na-22, Al-26, Cl-36, Mn-54, Co-60, Au-195, Ra-226, Ra-228, Th-228, and U-238 - were chosen to test all pathways and models. Tritium, Ra-226, and Th-228 were chosen because of the special tritium and radon models in the RESRAD-BUILD code. Other radionuclides were selected to represent a spectrum of radiation types and energies. Verification of the RESRAD-BUILD code was conducted with an initial check of all the input parameters for correctness against their original source documents. Verification of the calculations was performed external to the RESRAD-BUILD code with Microsoft ${ }^{\circledR}$ Excel to verify all the major portions of the code. In some cases, RESRAD-BUILD results were compared with those of external codes, such as MCNP (Monte Carlo N-particle) and RESRAD. The verification was conducted on a step-by-step basis and used different test cases as templates. The following types of calculations were investigated: (1) source injection rate, (2) air concentration in the room, (3) air particulate deposition, (4) radon pathway model, (5) tritium model for volume source, (6) external exposure model, (7) different pathway doses, and (8) time dependence of dose. Some minor errors were identified in version 3.0; these errors have been corrected in later versions of the code. Some possible improvements in the code were also identified.
\end{abstract}

\section{INTRODUCTION}

This study was conducted to verify the results generated by the RESRAD-BUILD code with hand or spreadsheet calculations performed with equations given in the RESRAD-BUILD manual (Yu et. al. 1994).

The RESRAD-BUILD computer code is a pathway analysis model designed to evaluate the potential radiological dose to an individual who works or lives in a building contaminated with radioactive material. The models in RESRAD-BUILD can be used to assess long-term chronic exposure situations, but generally they cannot be used for transient or accident situations. The code can model up to three compartments in a building. The transport of radioactive material inside the building from one compartment to another is calculated with an indoor air quality 
model. The code considers the releases into the indoor air by diffusion (radon gas), mechanical removal (decontamination activities), or erosion (removable surface contamination). These three release mechanisms were tested, and the results are presented in this report. Currently, the RESRAD-BUILD database contains 67 radionuclides. For verification purposes, different radionuclides - H-3, C-14, Na-22, Al-26, Cl-36, Mn-54, Co-60, Au-195, Ra-226, Ra-228, Th-228, and U-238 - were chosen to test all pathways and models. Tritium, Ra-226, and Th-228 were chosen because of the special tritium and radon models in the RESRAD-BUILD code. Other radionuclides were selected to represent a spectrum of radiation types and energies.

The RESRAD-BUILD code considers seven exposure pathways: (1) external exposure directly from the source (i.e., the source geometry could be contaminated floors, walls, ceilings, or any other object); (2) external exposure to materials deposited on the floor; (3) external exposure due to air submersion; (4) inhalation of airborne radioactive particulates; (5) inhalation of aerosol indoor radon progeny; (6) inadvertent ingestion of radioactive material directly from the sources; and (7) inadvertent ingestion of materials deposited on the surfaces of the building rooms or compartments. The verification of the RESRAD-BUILD code was performed for individual pathway dose computations. A single run of the RESRAD-BUILD code can model a building with up to 3 rooms or compartments, 10 distinct source locations, 4 source geometries (volume, area or surface, line, and point), 10 receptor locations, 8 shielding materials, and 10 radionuclides in a source.

Verification of the RESRAD-BUILD code (version 3.0) was conducted with an initial check of all the input parameters for correctness against their original source documents (see Section 2). Verification of the calculations was performed external to the RESRAD-BUILD code with Microsoft ${ }^{\circledR}$ Excel (version 7) to verify all the major portions of the code. The verification was conducted on a step-by-step basis and used different test cases as templates, since all possible options could not be considered in a single analysis. The following types of calculations were investigated:

- Source injection rate,

- Air concentration in the room,

- Air particulate deposition,

- Radon pathway model,

- Tritium model for volume source,

- External exposure model, 
- Different pathway doses, and

- Time dependence of dose.

The total receptor dose from all pathways, except direct external exposure, depends on the radionuclide air concentration in the room. The radionuclide air concentration, in turn, depends on the source injection rate. Therefore, the source injection rate calculations were verified first (see Section 3). In turn, the air concentration in a one-room and two-room model was verified (see Section 4). The air deposition depends on the air concentration in the room; therefore, air deposition was verified next (see Section 4). RESRAD-BUILD has special radon and tritium models; verification of these models is discussed in Sections 5 and 6, respectively. The external exposure models in RESRAD-BUILD were independently benchmarked with the Monte Carlo N-Particle (MCNP) transport code (Briesmeister 1993) (see Section 7). Verification of the individual pathways in RESRAD-BUILD is discussed in Section 8. Finally, the total dose calculated by RESRAD-BUILD for a single receptor was compared with that calculated by the Excel spreadsheet. The time-independent part of the code was tested first (instantaneous dose calculations at time zero without averaging over one year or exposure duration). Verification of the time-dependent part of the code is presented in Section 9. Section 10 provides conclusions, and Section 11 discusses the limitations of this verification and gives suggestions for future improvement of the code. The output files from the RESRAD-BUILD (version 3.0) verification runs are provided in the Appendix. (This appendix is provided in the companion CD-ROM to this document.) 


\section{PARAMETER VERIFICATION}

The following parameters used in the RESRAD-BUILD code (version 3.0) were first checked for correctness against their original source documents: inhalation, ingestion, air submersion, and external dose conversion factors (DCFs); external exposure model parameters; and radionuclide half-lives and other decay data. The files checked were nucdcf.dat, GP_ABS.LIB, and coeff_bd.lib.

The nucdcf.dat file contains DCFs for ingestion, inhalation, external-surface, externalvolume, and immersion pathways. It also includes half-lives, total number of gammas emitted, and the number of branching radionuclides. The values of external-surface DCFs are not used in any calculations and may be removed from the nucdcf.dat file. The values of half-lives in the nucdf.dat file have only three significant digits; the significant digits should be increased to match the actual half-lives of radionuclides. Table 2.1 lists the errors noted in the nucdcf.dat file.

The GP_ABS.LIB file contains the geometric progression (G-P) buildup factor coefficients for different materials available in the RESRAD-BUILD code. For some materials, energy absorption buildup factor coefficients were used rather than exposure buildup factor coefficients. It is recommended that G-P exposure buildup factor coefficients be used for all materials.

The coeff_bd.lib file contains parameters required to compute the external pathway dose for surface (area) and volume sources. The parameters are the external DCFs for volume sources, fitted coefficients of the external exposure model, collapsed gamma energies, ${ }^{1}$ and respective gamma fractions of radionuclides (Kamboj et al. 1998). The GP_ABS.LIB file has only two significant digits for some of the external exposure model parameters. The significant digits should be increased to three to obtain a better estimation of the external pathway dose for a surface and volume source.

TABLE 2.1 Errors Noted in nucdef.dat File

\begin{tabular}{lccc}
\hline \multicolumn{1}{c}{ Parameter } & Nuclide & Present Value & Correct Value \\
\hline & & & \\
Half-life (yr) & Ac-227 & $2.17 \mathrm{E}+01$ & $2.18 \mathrm{E}+01$ \\
Half-life (yr) & $\mathrm{Zn}-65$ & $6.67 \mathrm{E}-01$ & $6.68 \mathrm{E}-01$ \\
Inhalation DCF $(\mathrm{mrem} / \mathrm{pCi})$ & $\mathrm{Ce}-144$ & $2.16 \mathrm{E}-04$ & $3.74 \mathrm{E}-04$ \\
Inhalation DCF $(\mathrm{mrem} / \mathrm{pCi})$ & Pm-147 & $2.58 \mathrm{E}-05$ & $3.92 \mathrm{E}-05$ \\
\hline
\end{tabular}

\footnotetext{
1 To conserve computational time without sacrificing accuracy, the photon energies and yields from International Commission on Radiological Protection (ICRP) Publication 38 (ICRP 1983) were condensed into a smaller number of energies and yields for each radionuclide. The spectra-condensing algorithms, which conserve energy, repeatedly combine the photons that are closest in their energies (using their ratio).
} 
For verification of the calculations, Excel spreadsheets were prepared that calculated the different pathway doses according to the source receptor configuration. Three spreadsheets were used for all verification runs. The first spreadsheet contains all the RESRAD-BUILD default parameters, the second has lower values of the input parameters, and the third has all the upper values for the input parameters. The lower and upper values of the parameters are from $\mathrm{Yu}$ et al. (2000). The verification was performed for three data sets to cover wide variations in input values. Table 2.2 gives the input parameter values that were used for comparison, the parameter names used in the dose calculations, and the units for each parameter. In some cases, the units vary. For example, the radionuclide concentration for a volume source is input in $\mathrm{pCi} / \mathrm{g}$, and in the calculations, source concentration used may be in $\mathrm{pCi} / \mathrm{kg}$; deposition velocity is input in $\mathrm{m} / \mathrm{s}$, and in the calculations, it is used in units of $\mathrm{m} / \mathrm{h}$.

For RESRAD-BUILD many input test case files (in all 17) were generated. The first case included four Na-22 sources, four Al-26 sources (one each of volume, surface, line, and point sources), and one H-3 volume source, all with RESRAD-BUILD default values. The second and third cases were with the same sources with lower and upper parameter bound values. RESRADBUILD allows only 10 sources as input in a single run; therefore, 3 separate cases with default, lower, and upper bound values were generated with Ra-226 and Th-228 point and volume sources. To verify the two-room air quality model, three more case files with default, lower bound, and upper bound parameter values, respectively, were used. To verify the external exposure model for point, line, area, and volume sources, four separate case files were used. Table 2.3 lists all the case files used in the verification of different calculations. The RESRADBUILD output files generated and used are also listed. All RESRAD-BUILD input and output files are provided in the Appendix. 
TABLE 2.2 Parameters and Parameter Values Used in RESRAD-BUILD Verification

\begin{tabular}{|c|c|c|c|c|}
\hline \multirow[b]{2}{*}{ Parameter } & \multirow[b]{2}{*}{ Parameter Name } & \multicolumn{3}{|c|}{ Parameter Value } \\
\hline & & Default & Lower ${ }^{\mathrm{a}}$ & Upper $^{\mathrm{a}}$ \\
\hline Exposure duration, $\mathrm{d}$ & $\mathrm{ED}$ & 365 & 365 & 365 \\
\hline Indoor fraction & $\mathrm{F}_{\mathrm{IN}}$ & 0.5 & 0.205 & 1.0 \\
\hline Evaluation time, yr & $\mathrm{t}$ & 0 & 0 & 0 \\
\hline Deposition velocity, $\mathrm{m} / \mathrm{s}$ & $\mathrm{U}_{\mathrm{d}}$ & 0.01 & 0 & 0.01 \\
\hline Resuspension rate, $1 / \mathrm{s}$ & $\lambda_{\mathrm{R}}$ & $5.0 \mathrm{E}-07$ & $1.2 \mathrm{E}-10$ & $4 \mathrm{E}-04$ \\
\hline Room height (room 1), $\mathrm{m}$ & $\mathrm{H}_{1}$ & 2.5 & 1.67 & 3.75 \\
\hline Room height (room 2), $\mathrm{m}$ & $\mathrm{H}_{2}$ & 2.5 & 1.67 & 3.75 \\
\hline Room area (room 1$), \mathrm{m}^{2}$ & $\mathrm{~A}_{1}$ & 36 & 3.6 & 360 \\
\hline Room area (room 2), $\mathrm{m}^{2}$ & $\mathrm{~A}_{2}$ & 36 & 3.6 & 360 \\
\hline Air exchange rate for building, $1 / \mathrm{h}$ & $\lambda^{\mathrm{a}} \mathrm{b}_{\mathrm{b}}$ & 0.8 & 0.1796 & 1.5185 \\
\hline Air flow from outside to compartment 1 & $\mathrm{Q}_{01}($ flow01) & 84 & 1.16 & 4,065 \\
\hline Air flow from outside to compartment 2 & $\mathrm{Q}_{02}$ (flow02) & 60 & 1 & 35 \\
\hline Air flow from compartment 1 to compartment 2 & $\mathrm{Q}_{12}$ (flow12) & 30 & 4 & 180.2 \\
\hline Air flow from compartment 2 to compartment 1 & $\mathrm{Q}_{21}$ (flow21) & 30 & 4.5 & 175.2 \\
\hline Number of receptors & $N A^{b}$ & 1 & 1 & 1 \\
\hline Receptor inhalation rate, $\mathrm{m}^{3} / \mathrm{d}$ & IR & 18 & 12 & 45.6 \\
\hline Receptor location, $\mathrm{m}$ & NA & $1,1,1$ & $1,1,1$ & $5,5,1$ \\
\hline Receptor indirect ingestion rate, $\mathrm{m}^{2} / \mathrm{h}$ & SER & 0.0001 & 0.0001 & 0.011 \\
\hline Receptor time in room 1 & $\mathrm{FI}_{1}$ & 1 & 1 & 1 \\
\hline Receptor time in room 2 & $\mathrm{FI}_{2}$ & 1 & 1 & 1 \\
\hline Number of sources & NA & 1 & 1 & 1 \\
\hline Source location, $\mathrm{m}$ & NA & $0,0,0$ & $0,0,0$ & $0,0,0$ \\
\hline Source length or area $\left(\mathrm{m}, \mathrm{m}^{2}\right)$ & $\mathrm{L}_{\mathrm{s}}, \mathrm{A}_{\mathrm{s}}$ & 36 & 3.6 & 360 \\
\hline Air release fraction & $\mathrm{f}$ & 0.1 & 0.01 & 1 \\
\hline Direct ingestion rate, $\mathrm{g} / \mathrm{h}$ (volume source) & ER & 0 & 0 & 0.0025 \\
\hline Direct ingestion rate, $1 / \mathrm{h}$ (area, line, and point) & $\mathrm{ER}_{1}$ & 0 & 0 & 0.00005 \\
\hline Removable fraction & $f_{R}$ & 0.5 & 0.01 & 0.5 \\
\hline Time for source removal or source lifetime, $\mathrm{d}$ & $\mathrm{T}_{\mathrm{R}}$ & 365 & 365 & 36,500 \\
\hline $\begin{array}{l}\text { Radionuclide concentration, } \mathrm{pCi} / \mathrm{g} \text { (volume); } \\
\text { pCi } / \mathrm{m}^{2} \text { (surface); } \mathrm{pCi} / \mathrm{m} \text { (line); } \mathrm{pCi} \text { (point) }\end{array}$ & $\mathrm{C}^{\mathrm{n}}{ }_{\mathrm{S}}, \mathrm{Q}^{\mathrm{n}_{\mathrm{S}}}$ & 1 & 1 & 1 \\
\hline Source material & NA & Concrete & Concrete & Concrete \\
\hline Number of regions in volume source & NA & 1 & 1 & 1 \\
\hline Contaminated region - volume source & NA & 1 & 1 & 1 \\
\hline Source thickness, $\mathrm{cm}$ & $\mathrm{t}_{\mathrm{s}}$ & 15 & 5 & 30 \\
\hline Source density, $\mathrm{g} / \mathrm{cm}^{3}$ & $\rho_{\mathrm{bs}}$ & 2.4 & 2 & 4 \\
\hline Source erosion rate, $\mathrm{cm} / \mathrm{d}$ & $\mathrm{E}$ & $2.4 \mathrm{E}-08$ & $2.4 \mathrm{E}-10$ & 2.4E-06 \\
\hline Shielding material & NA & NA & NA & Concrete \\
\hline Shielding thickness, $\mathrm{cm}$ & $\mathrm{t}_{\mathrm{c}}$ & 0 & 0 & 15 \\
\hline Shielding density, $\mathrm{g} / \mathrm{cm}^{3}$ & $\rho_{c}$ & NA & NA & 2.4 \\
\hline Dry zone thickness, $\mathrm{cm}$ & $\mathrm{h}$ & 0 & 0 & 5 \\
\hline Wet + dry zone thickness, $\mathrm{cm}$ & $\mathrm{h}_{\mathrm{p}}$ & 10 & 5 & 30 \\
\hline Moisture content in the wet zone & $\mathrm{W}$ & 0.03 & 0.02 & 0.06 \\
\hline Water fraction available for evaporation & $\mathrm{f}_{\text {rel }}$ & 1 & 0.1 & 1 \\
\hline Humidity, $\mathrm{g} / \mathrm{m}^{3}$ & $\mathrm{C}_{\mathrm{g}, \mathrm{amb}}$ & 8 & 3 & 16.5 \\
\hline Source porosity & $\mathrm{n}$ & 0.1 & 0.05 & 0.2 \\
\hline Radon release fraction & $\mathrm{F}^{\mathrm{Rn}}$ & 0.1 & 0.02 & 0.5 \\
\hline
\end{tabular}


TABLE 2.2 (Cont.)

\begin{tabular}{lcccc}
\hline & & \multicolumn{3}{c}{ Parameter Value } \\
\cline { 3 - 5 } \multicolumn{1}{c}{ Parameter } & Parameter Name & Default & Lower $^{\mathrm{a}}$ & Upper $^{\mathrm{a}}$ \\
\hline & & & & \\
Rn-222 emanation coefficient & $\varepsilon$ & 0.2 & 0.04 & 1.0 \\
Rn-220 emanation coefficient & $\varepsilon$ & 0.2 & 0.04 & 1.0 \\
Radon effective diffusion coefficient, $\mathrm{m}^{2} / \mathrm{s}$ & $\mathrm{D}_{\mathrm{e}}$ & $2.0 \mathrm{E}-05$ & $2.0 \mathrm{E}-06$ & $2.0 \mathrm{E}-04$ \\
\hline
\end{tabular}

a The lower and upper parameter values are from Yu et al. (2000).

${ }^{\mathrm{b}} \mathrm{NA}=$ not applicable. 


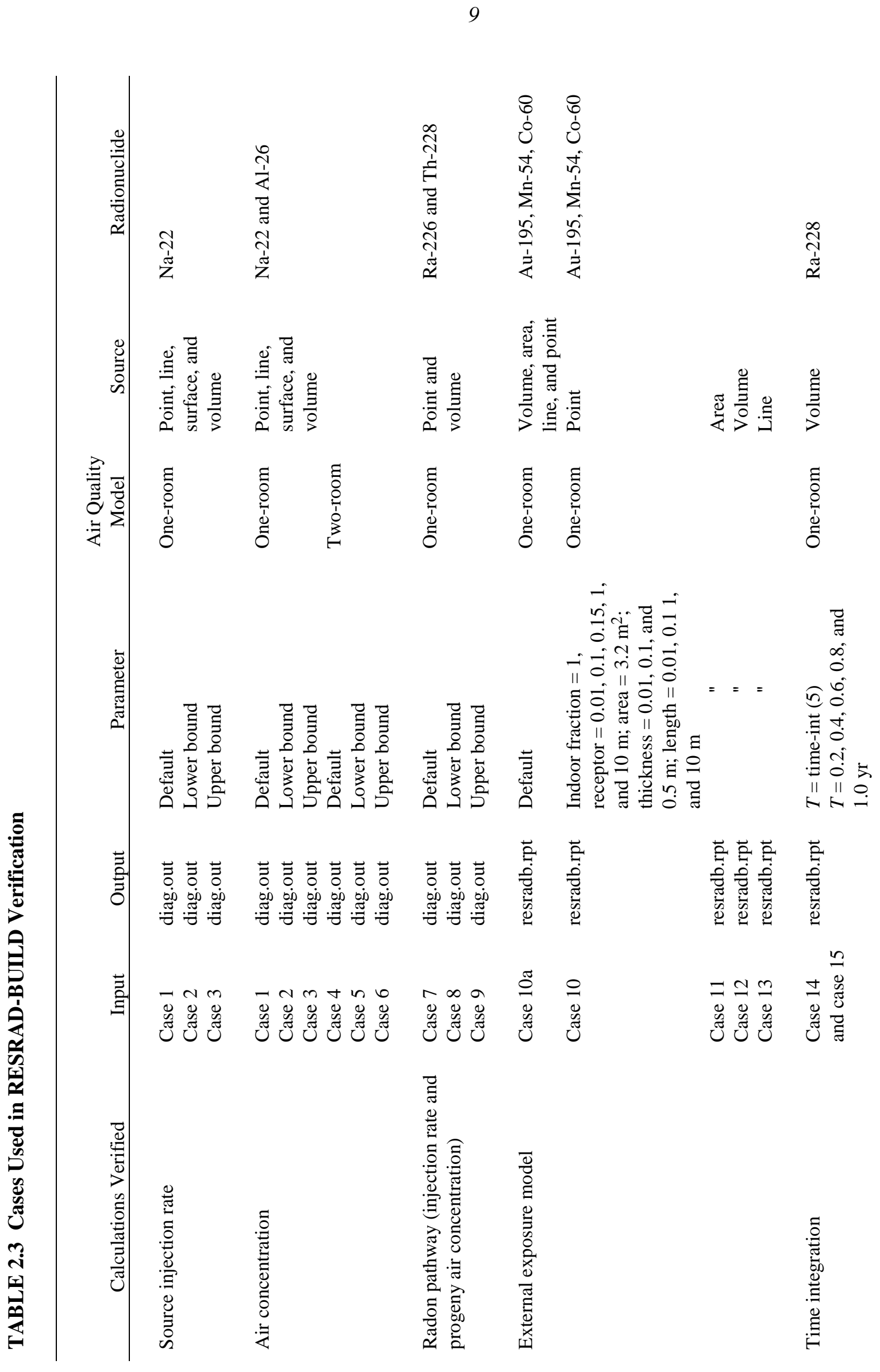




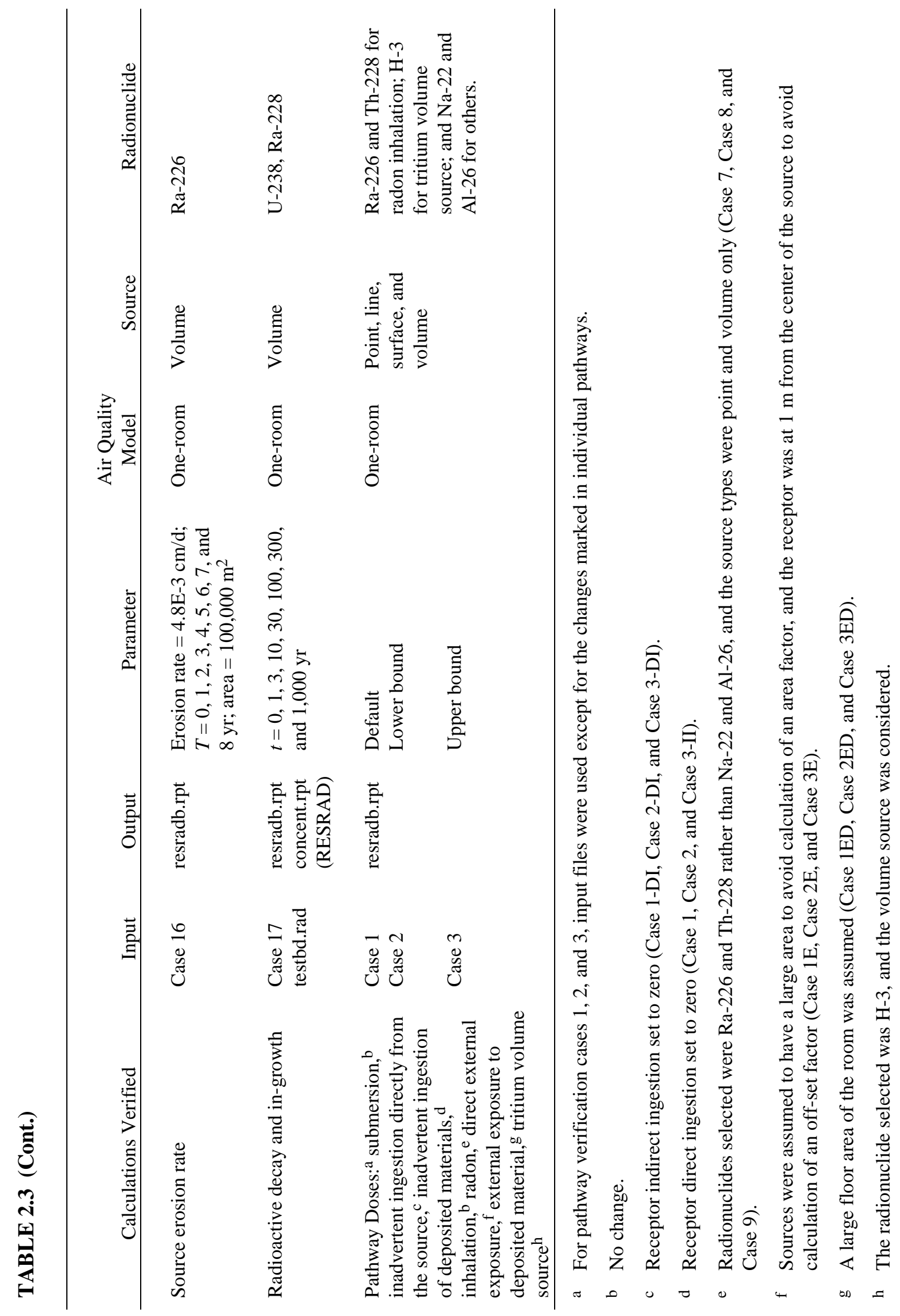




\section{SOURCE INJECTION RATE}

For a volume source, the release rate of a principal radionuclide $n$ into compartment $i$ is calculated by (Yu et al. 1994, Equation D.1):

$$
I_{S i}^{n}=\frac{f E A_{s} \rho_{b s} C_{s}^{n}}{8,760}
$$

where

$$
\begin{aligned}
I_{S i}^{n}= & \begin{aligned}
& \text { injection rate of radionuclide } n \text { into the indoor air of compartment } i \\
&(\mathrm{pCi} / \mathrm{h}), \\
& f= \text { fraction of mechanically removed or eroded material that becomes } \\
& \text { indoor dust (air release fraction), }
\end{aligned} \\
E= & \text { source removal or erosion rate }(\mathrm{m} / \mathrm{yr}), \\
A_{s}= & \text { effective surface area of the source }\left(\mathrm{m}^{2}\right), \\
\rho_{b s}= & \text { bulk density of the source material }\left(\mathrm{kg} / \mathrm{m}^{3}\right), \\
C_{S}^{n}= & \text { radionuclide concentration in the source material }(\mathrm{pCi} / \mathrm{kg}), \text { and }
\end{aligned}
$$

For surface, line, and point sources, the release rate of a principal radionuclide $n$ into compartment $i$ is calculated by (Yu et al. 1994, Equation D.2):

$$
I_{S i}^{n}=\frac{f_{R} f Q_{s}^{n}}{24 T_{R}},
$$

where

$f_{R}=$ removable fraction of the source material,

$f=$ fraction of removed material that becomes indoor dust (air release fraction), 
$Q_{S}^{n}=$ total radionuclide activity in the source $(\mathrm{pCi})$,

$T_{R}=$ time to remove material from the source (d), and

24 = time conversion factor (number of hours per day) $(\mathrm{h} / \mathrm{d})$.

Table 3.1 presents a comparison of the calculated injection rate for volume, area, line, and point sources. RESRAD-BUILD results from test cases 1, 2, and 3 are compared with the spreadsheet calculations. Equation 3.1 (Equation D.1 in Appendix D of the RESRAD-BUILD manual) was used in the spreadsheet to calculate the injection rate for a volume source, and Equation 3.2 (Equation D.2 in Appendix D of the RESRAD-BUILD manual) was used for area, line, and point sources. Figure 3.1 shows the spreadsheet calculations for the default parameter set. Table 3.1 gives the RESRAD-BUILD and spreadsheet calculated values of the source injection rate for the three sets of parameters for Na-22. The Appendix has the code generated diag.out file for test cases 1,2, and 3, which includes the source injection rate for all four source types (point, line, surface, and volume). The injection rate depends on the source concentration at time zero. The source injection models (Equations 3.1 and 3.2) are used for all radionuclides except for the H-3 volume source and radon progeny radionuclides. The injection rates for the tritium volume source and radon progeny are discussed in Sections 5 and 6, respectively. The RESRAD-BUILD detailed output file (diag.out) reported source injection rate results in $\mathrm{pCi} / \mathrm{s}$ and only to two significant digits; therefore, for comparison, the spreadsheet calculated source injection rate in $\mathrm{pCi} / \mathrm{h}$ (according to the RESRAD-BUILD manual) was converted to $\mathrm{pCi} / \mathrm{s}$. Excellent agreement was obtained between the RESRAD-BUILD generated results and the spreadsheet calculations. However, the significant digits in the diag.out file should be increased, or the units of the injection rate changed to $\mathrm{pCi} / \mathrm{h}$. 


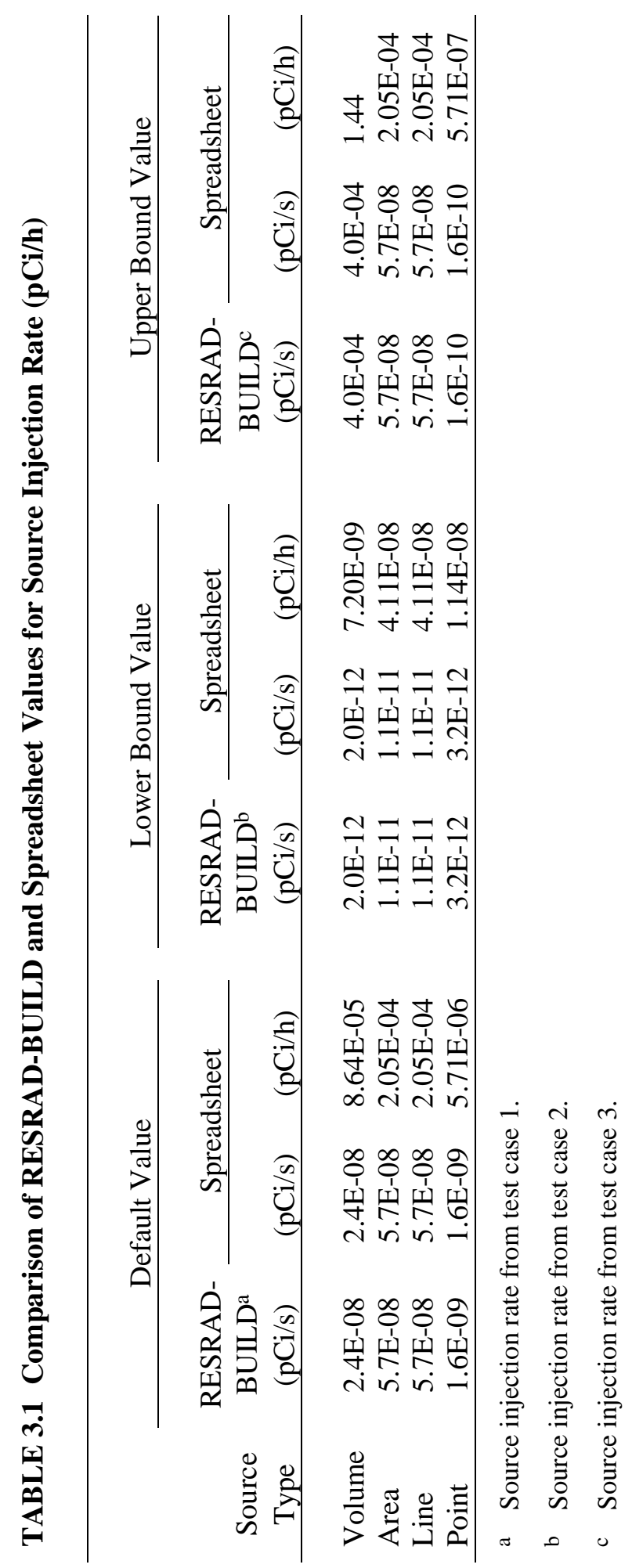


IS1N is the source-dependent term representing the direct injection rate of a principal radionuclide $n$ into compartment 1

IS1N for volume sources is given as:

$\operatorname{IS} 1 \mathrm{~N}(\mathrm{pCi} / \mathrm{h})=(\mathrm{f} * \mathrm{E} *$ As_1 * rhoebs * CSN $) / 8,760 \quad$ (Eq. 3.1)

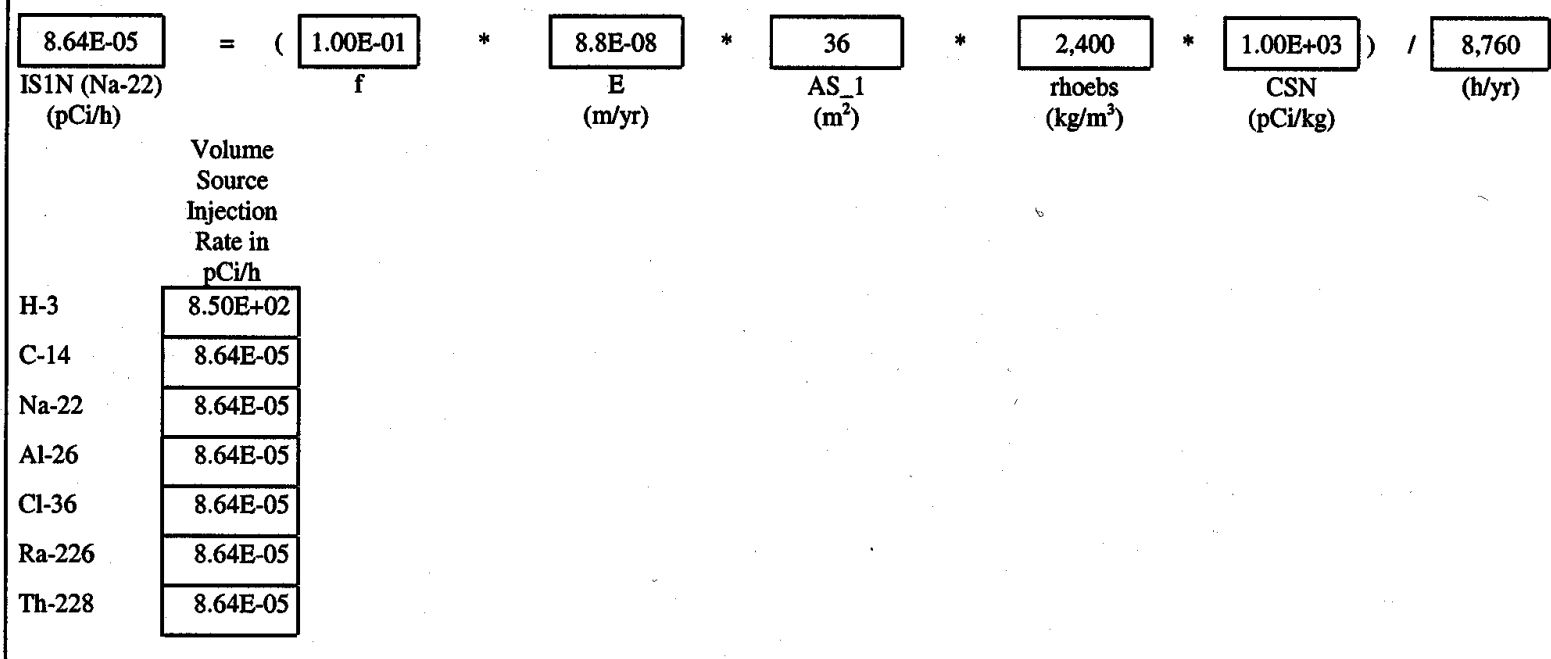

IS1N for surface, line, and point sources is given as:

$\operatorname{IS} 1 \mathrm{~N}(\mathrm{pCi} / \mathrm{h})=\mathrm{fR} * \mathrm{f} * \mathrm{QSN} /(24 * \mathrm{TR}) \quad$ (Eq. 3.2)

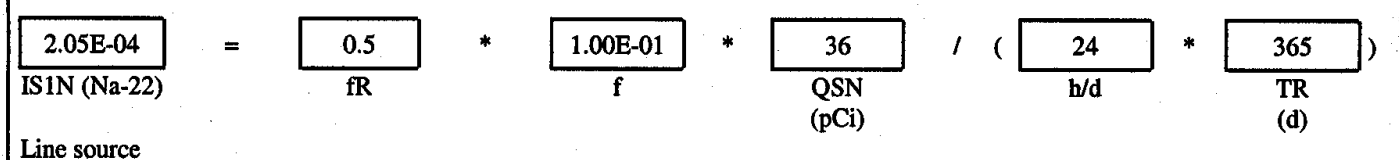

Line source

$(\mathrm{pCi} / \mathrm{h})$

Injection Rate in $\mathrm{pCi} / \mathrm{h}$

\begin{tabular}{|c|c|c|c|}
\hline & Point & Line & Surface \\
\hline $\mathrm{H}-3$ & $5.71 \mathrm{E}-06$ & $2.05 \mathrm{E}-04$ & $2.05 \mathrm{E}-04$ \\
\hline C-14 & $5.71 \mathrm{E}-06$ & $2.05 \mathrm{E}-04$ & $2.05 \mathrm{E}-04$ \\
\hline $\mathrm{Na}-22$ & $5.71 \mathrm{E}-06$ & $2.05 \mathrm{E}-04$ & $2.05 \mathrm{E}-04$ \\
\hline Al-26 & $5.71 \mathrm{E}-06$ & $2.05 \mathrm{E}-04$ & $2.05 \mathrm{E}-04$ \\
\hline $\mathrm{Cl}-36$ & $5.71 \mathrm{E}-06$ & $2.05 \mathrm{E}-04$ & $2.05 \mathrm{E}-04$ \\
\hline $\mathrm{Ra}-226$ & $5.71 \mathrm{E}-06$ & $2.05 \mathrm{E}-04$ & $2.05 \mathrm{E}-04$ \\
\hline Th-228 & $5.71 \mathrm{E}-06$ & 2.05E-04 & $2.05 \mathrm{E}-04$ \\
\hline
\end{tabular}

FIGURE 3.1 Source Injection Rate Calculations for Volume, Surface, Line, and Point Sources 


\section{AIR CONCENTRATION AND PARTICULATE DEPOSITION}

From the one-room air quality model, the air concentration of principal radionuclide $n$ (derived from Equation A.28 in the RESRAD-BUILD manual) can be given as:

$$
C_{1}^{n}=\frac{I_{S 1}^{n}}{\left(\lambda_{r n}+\lambda_{d 1}-\frac{\lambda_{R} \lambda_{d 1}}{\lambda_{r n}+\lambda_{R}}\right) V_{1}+Q_{01}},
$$

where

$$
\begin{aligned}
& C_{1}^{n}=\text { air concentration of radionuclide } n \text { in compartment } 1, \\
& \lambda_{r n}=\text { radioactive decay constant of radionuclide } n \\
& \lambda_{d 1}=\text { deposition rate in compartment } 1 \\
& \lambda_{R}=\text { resuspension rate, } \\
& V_{1}=\text { volume of compartment } 1, \text { and } \\
& Q_{01}=\text { flow of air from compartment } 1 \text { to the outside. }
\end{aligned}
$$

The deposition rate can be given as:

$$
\lambda_{d 1}=\frac{u_{d} A_{1}}{V_{1}},
$$

where

$u_{d}=$ deposition velocity, and

$A_{1}=$ area of compartment (room) 1.

For the one-room model, the flow of air from compartment 1 to the outside can be calculated as:

$$
Q_{01}=\lambda_{b}^{a} V_{1},
$$

where $\lambda_{b}^{a}$ is the building air exchange rate. 
Figure 4.1 shows the calculated air concentration using the default parameter set for all seven radionuclides for the volume, area, line, and point sources. Equations 4.1 through 4.3 were used in these calculations. Table 4.1 provides the RESRAD-BUILD (test cases 1, 2, and 3) and spreadsheet calculated values of the air concentration for the three sets of parameters (default, lower bound, and upper bound) for the one-room model. The diag.out files for cases 1, 2, and 3 in the Appendix include the RESRAD-BUILD code generated air concentrations for four source types for the one-room air quality model. As shown in Table 4.1 for the Na-22 and Al-26 radionuclides at time zero, excellent agreement was obtained between the RESRAD-BUILD and spreadsheet calculations.

For the two-room air quality model, the air concentration of principal radionuclide $n$ (derived from Equation A.28 in the RESRAD-BUILD manual) can be given as:

$$
C_{1}^{n}=\frac{D_{1} I_{S 2}^{n}+D_{2} I_{S 1}^{n}}{C_{1} D_{2}-D_{1} C_{2}}
$$

and

$$
C_{2}^{n}=\frac{C_{1} I_{S 2}^{n}+C_{2} I_{S 1}^{n}}{C_{1} D_{2}-D_{1} C_{2}}
$$

The injection rates in compartments 1 and 2 were calculated using Equations 3.1 and 3.2 for volume, area, line, and point sources. The $C_{1}, C_{2}, D_{1}$, and $D_{2}$ parameters were given as:

$$
\begin{aligned}
& C_{1}=\left(\lambda_{r n}+\lambda_{d 1}-\frac{\lambda_{R} \lambda_{d 1}}{\lambda_{r n}+\lambda_{R}}\right) V_{1}+Q_{01}+Q_{21}, \\
& C_{2}=Q_{12}, \\
& D_{1}=Q_{21}, \text { and } \\
& D_{2}=\left(\lambda_{r n}+\lambda_{d 2}-\frac{\lambda_{R} \lambda_{d 2}}{\lambda_{r n}+\lambda_{R}}\right) V_{2}+Q_{02}+Q_{12} .
\end{aligned}
$$




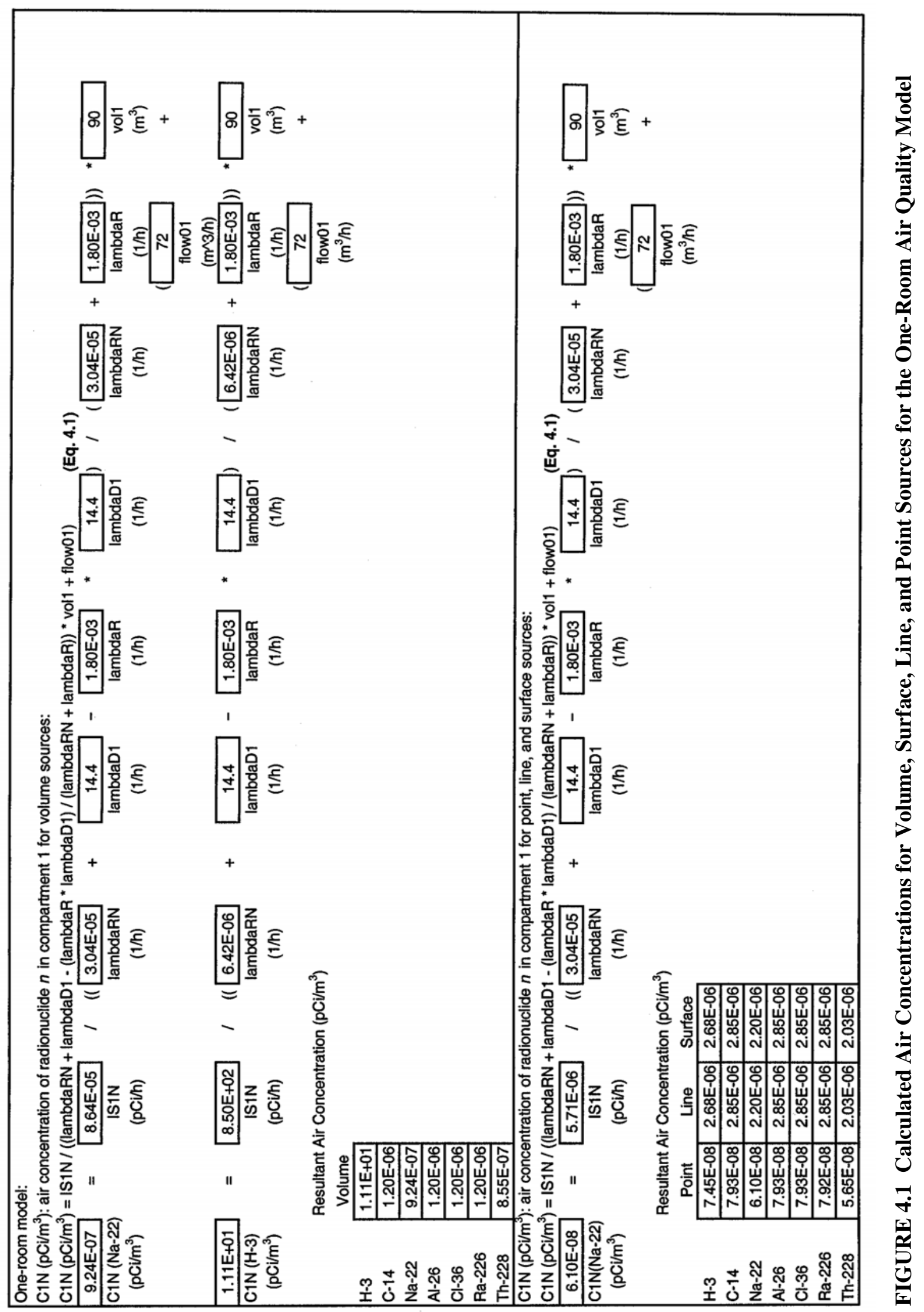


TABLE 4.1 RESRAD-BUILD and Spreadsheet Air Concentration $\left(\mathrm{pCi} / \mathrm{m}^{3}\right)$ Values for the One-Room Air Quality Model

\begin{tabular}{|c|c|c|c|c|c|c|}
\hline \multirow[b]{2}{*}{$\begin{array}{c}\text { Source } \\
\text { Type }\end{array}$} & \multicolumn{2}{|c|}{ Default } & \multicolumn{2}{|c|}{ Lower } & \multicolumn{2}{|c|}{ Upper } \\
\hline & $\begin{array}{l}\text { RESRAD- } \\
\text { BUILD }^{\mathrm{a}}\end{array}$ & Spreadsheet & $\begin{array}{l}\text { RESRAD- } \\
\text { BUILD }^{b}\end{array}$ & Spreadsheet & $\begin{array}{l}\text { RESRAD- } \\
\text { BUILD }^{c}\end{array}$ & Spreadsheet \\
\hline \multicolumn{7}{|l|}{$\mathrm{Na}-22$} \\
\hline Volume & $9.2 \mathrm{E}-07$ & $9.24 \mathrm{E}-07$ & $6.7 \mathrm{E}-09$ & $6.65 \mathrm{E}-09$ & 7.1E-04 & $7.11 \mathrm{E}-04$ \\
\hline Area & 2.2E-06 & $2.20 \mathrm{E}-06$ & $3.8 \mathrm{E}-08$ & $3.80 \mathrm{E}-08$ & $1.0 \mathrm{E}-07$ & $1.01 \mathrm{E}-07$ \\
\hline Line & $2.2 \mathrm{E}-06$ & $2.20 \mathrm{E}-06$ & $3.8 \mathrm{E}-08$ & $3.80 \mathrm{E}-08$ & $1.0 \mathrm{E}-07$ & $1.01 \mathrm{E}-07$ \\
\hline Point & $6.1 \mathrm{E}-08$ & $6.10 \mathrm{E}-08$ & $1.1 \mathrm{E}-08$ & $1.05 \mathrm{E}-08$ & $2.8 \mathrm{E}-10$ & $2.82 \mathrm{E}-10$ \\
\hline \multicolumn{7}{|l|}{ Al-26 } \\
\hline Volume & $1.2 \mathrm{E}-06$ & $1.20 \mathrm{E}-06$ & 6.7E-09 & $6.65 \mathrm{E}-09$ & 7.1E-04 & $7.11 \mathrm{E}-04$ \\
\hline Area & $2.9 \mathrm{E}-06$ & $2.85 \mathrm{E}-06$ & $3.8 \mathrm{E}-08$ & $3.80 \mathrm{E}-08$ & $1.0 \mathrm{E}-07$ & $1.01 \mathrm{E}-07$ \\
\hline Line & 2.9E-06 & $2.85 \mathrm{E}-06$ & $3.8 \mathrm{E}-08$ & $3.80 \mathrm{E}-08$ & $1.0 \mathrm{E}-07$ & $1.01 \mathrm{E}-07$ \\
\hline Point & 7.9E-08 & 7.93E-08 & $1.1 \mathrm{E}-08$ & $1.05 \mathrm{E}-08$ & $2.8 \mathrm{E}-10$ & $2.82 \mathrm{E}-10$ \\
\hline
\end{tabular}

The deposition rates for compartments 1 and 2 were calculated using Equation 4.2. The air flow rates, $Q_{21}$, quantity of air going from compartment 2 to compartment 1; $Q_{12}$, quantity of air going from compartment 1 to 2 ; $Q_{01}$, inflow to compartment 1 ; and $Q_{02}$, inflow to compartment 2 are required to calculate the air concentration. If the building parameters, such as building and room exchange rates, net flow between compartments 1 and 2, and inflow to compartment 2 are known, the air flow rates can be calculated. Unknown parameters can be calculated in many ways. For example, if the exchange rate for compartments 1 and $2\left(\lambda_{1}^{a}\right.$ and $\left.\lambda_{2}^{a}\right)$, net flow between compartments 1 and $2\left(N_{12}\right)$, and inflow to compartment 2 are known, then the other parameters can be calculated as:

$$
\begin{gathered}
Q_{12}=\lambda_{2}^{a}-Q_{02}, \\
Q_{21}=Q_{12}-N_{12}, \text { and } \\
Q_{01}=\lambda_{1}^{a} V_{1}-Q_{21} .
\end{gathered}
$$

Figures 4.2 and 4.3 show the calculated air concentration using the default parameter set for all seven radionuclides for the volume, point, line, and area sources, respectively. Figure 4.4 provides the in-between calculation results. Equations 4.4 through 4.12 were used in these calculations. Table 4.2 gives the RESRAD-BUILD (test cases 4, 5, and 6) and spreadsheet 


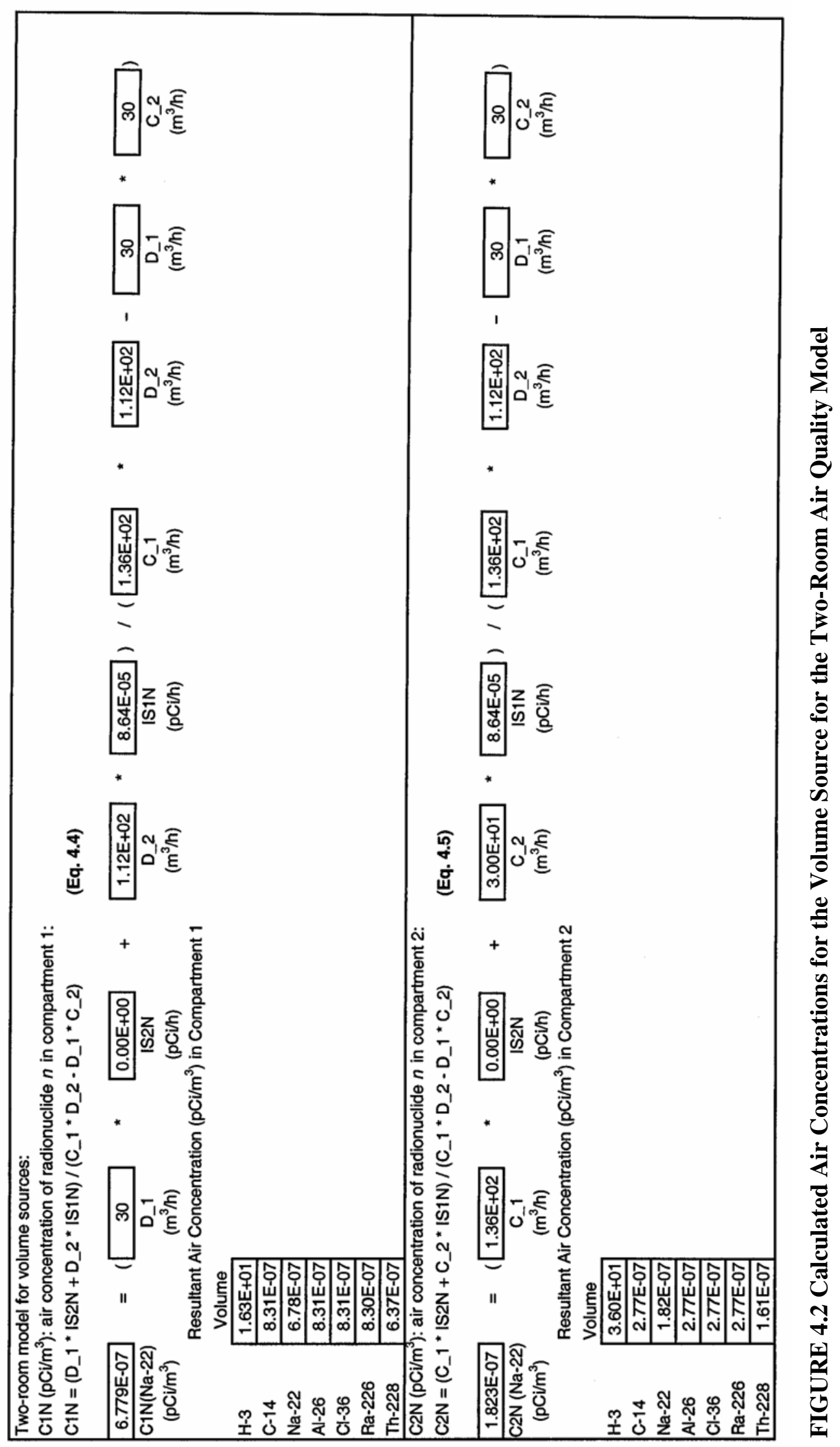




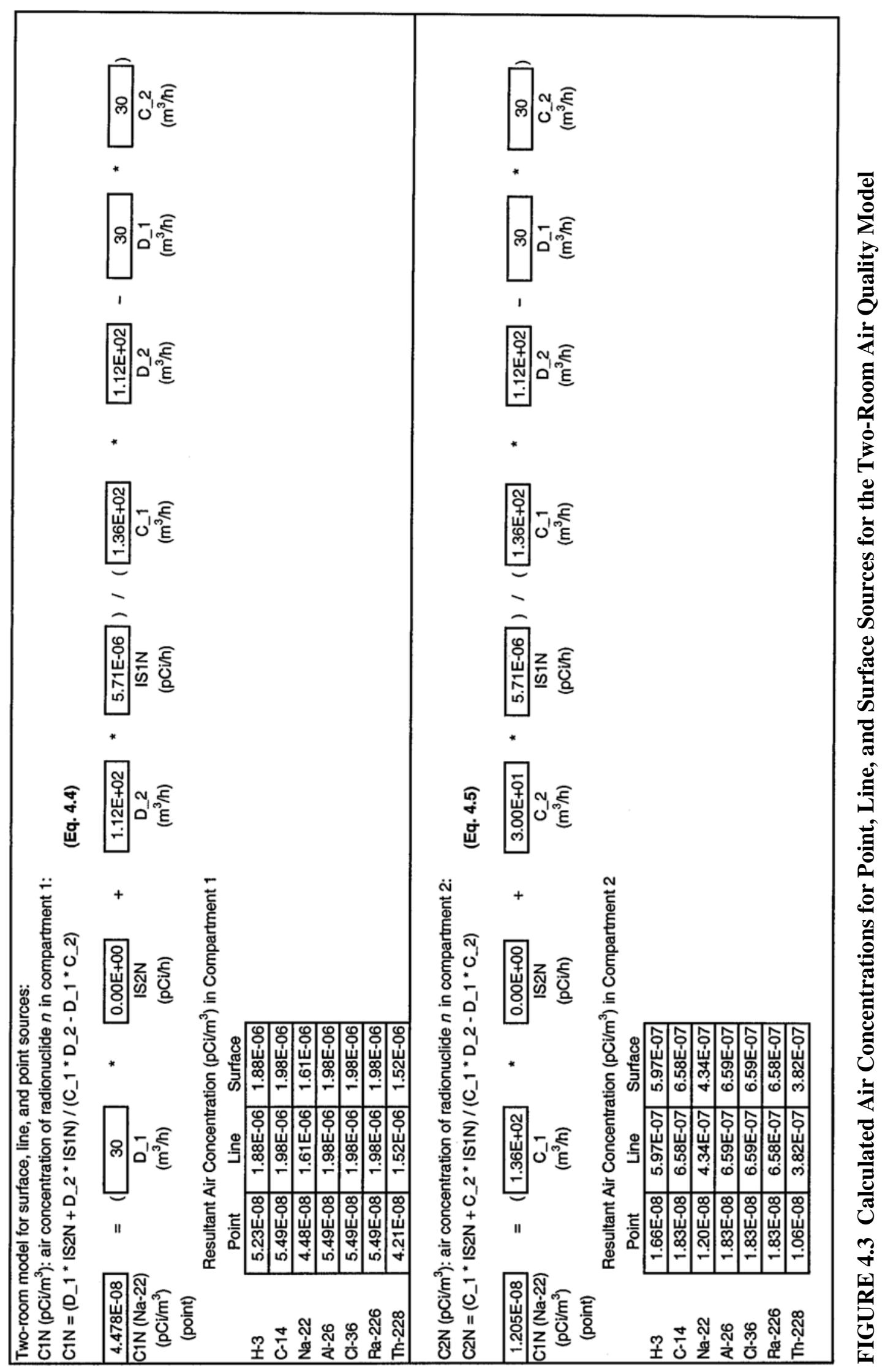




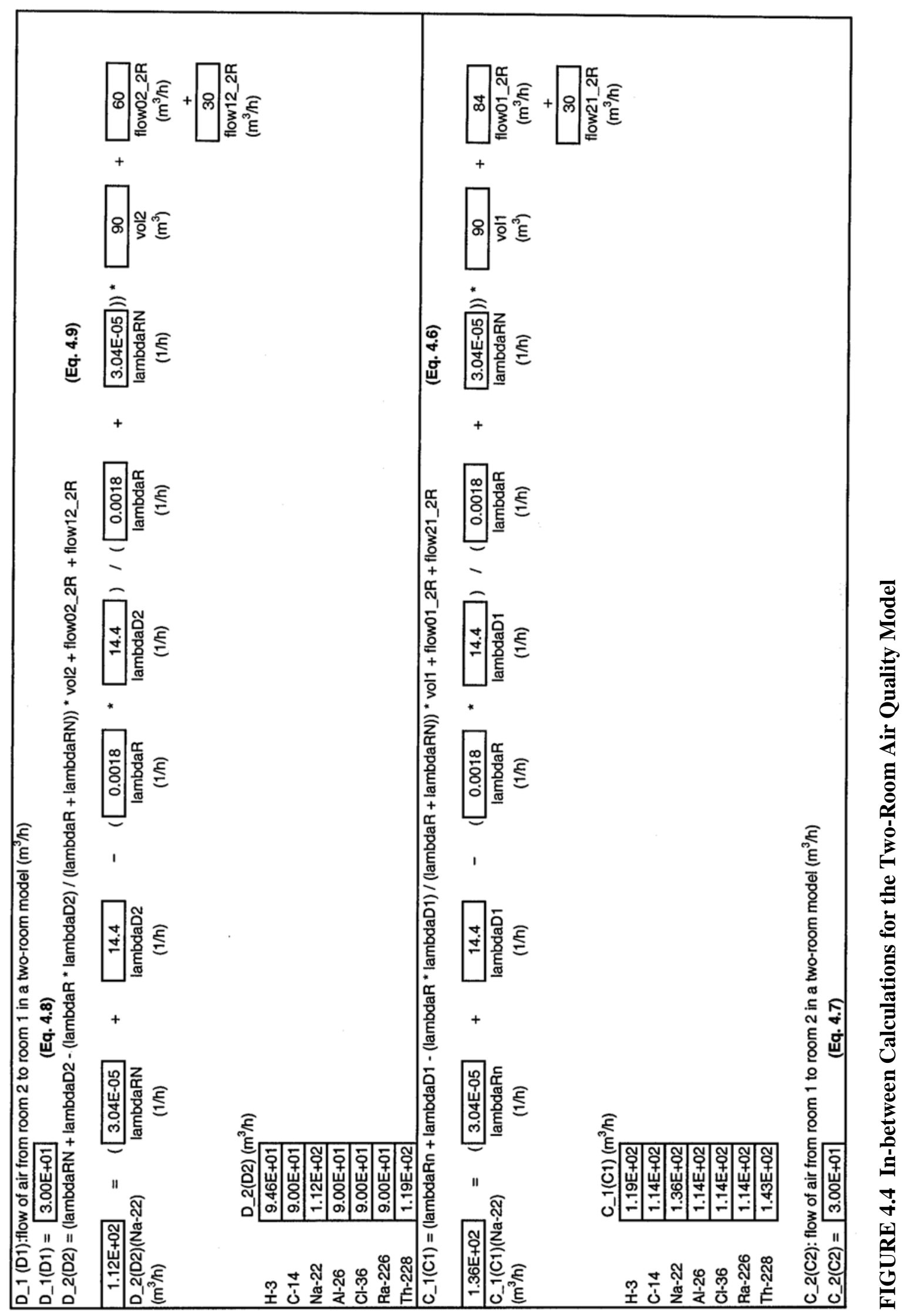


TABLE 4.2 RESRAD-BUILD and Spreadsheet Air Concentration $\left(\mathrm{pCi} / \mathrm{m}^{3}\right)$ Values for the Two-Room Air Quality Model

\begin{tabular}{|c|c|c|c|c|c|c|}
\hline \multirow[b]{2}{*}{$\begin{array}{c}\text { Source } \\
\text { Type }\end{array}$} & \multicolumn{2}{|c|}{ Default } & \multicolumn{2}{|c|}{ Lower } & \multicolumn{2}{|c|}{ Upper } \\
\hline & $\begin{array}{l}\text { RESRAD- } \\
\text { BUILD }^{\mathrm{a}}\end{array}$ & Spreadsheet & $\begin{array}{l}\text { RESRAD- } \\
\text { BUILD }^{b}\end{array}$ & Spreadsheet & $\begin{array}{l}\text { RESRAD- } \\
\text { BUILD }^{c}\end{array}$ & Spreadsheet \\
\hline \multicolumn{7}{|c|}{$\mathrm{Na}-22$ (Air concentration in room 1 with source in room 1 ) } \\
\hline Volume & $6.8 \mathrm{E}-07$ & $6.78 \mathrm{E}-07$ & $3.5 \mathrm{E}-09$ & 3.49E-09 & $3.5 \mathrm{E}-04$ & $3.52 \mathrm{E}-04$ \\
\hline Area & $1.6 \mathrm{E}-06$ & $1.61 \mathrm{E}-06$ & 2.0E-08 & $1.99 \mathrm{E}-08$ & 5.0E-08 & $5.02 \mathrm{E}-08$ \\
\hline Line & $1.6 \mathrm{E}-06$ & $1.61 \mathrm{E}-06$ & 2.0E-08 & $1.99 \mathrm{E}-08$ & $5.0 \mathrm{E}-08$ & $5.02 \mathrm{E}-08$ \\
\hline Point & 4.5E-08 & 4.48E-08 & $5.5 \mathrm{E}-09$ & $5.54 \mathrm{E}-09$ & $1.4 \mathrm{E}-10$ & $1.39 \mathrm{E}-10$ \\
\hline \multicolumn{7}{|c|}{$\mathrm{Na}-22$ (Air concentration in room 2 with source in room 1 ) } \\
\hline Volume & $1.8 \mathrm{E}-07$ & $1.82 \mathrm{E}-07$ & 2.8E-09 & $2.80 \mathrm{E}-09$ & 2.9E-04 & $2.94 \mathrm{E}-04$ \\
\hline Area & 4.3E-07 & 4.34E-07 & $1.6 \mathrm{E}-08$ & $1.60 \mathrm{E}-08$ & 4.2E-08 & $4.20 \mathrm{E}-08$ \\
\hline Line & 4.3E-07 & 4.34E-07 & $1.6 \mathrm{E}-08$ & $1.60 \mathrm{E}-08$ & 4.2E-08 & 4.20E-08 \\
\hline Point & $1.2 \mathrm{E}-08$ & $1.20 \mathrm{E}-08$ & 4.4E-09 & 4.43E-09 & $1.2 \mathrm{E}-10$ & $1.17 \mathrm{E}-10$ \\
\hline \multicolumn{7}{|c|}{ Al-26 (Air concentration in room 1 with source in room 1 ) } \\
\hline Volume & 8.3E-07 & 8.31E-07 & $3.5 \mathrm{E}-09$ & $3.49 \mathrm{E}-09$ & $3.5 \mathrm{E}-04$ & $3.52 \mathrm{E}-04$ \\
\hline Area & $2.0 \mathrm{E}-06$ & $1.98 \mathrm{E}-06$ & 2.0E-08 & $1.99 \mathrm{E}-08$ & $5.0 \mathrm{E}-08$ & $5.02 \mathrm{E}-08$ \\
\hline Line & $2.0 \mathrm{E}-06$ & $1.98 \mathrm{E}-06$ & $2.0 \mathrm{E}-08$ & $1.99 \mathrm{E}-08$ & 5.0E-08 & $5.02 \mathrm{E}-08$ \\
\hline Point & $5.5 \mathrm{E}-08$ & 5.49E-08 & $5.5 \mathrm{E}-09$ & $5.54 \mathrm{E}-09$ & $1.4 \mathrm{E}-10$ & $1.39 \mathrm{E}-10$ \\
\hline \multicolumn{7}{|c|}{ Al-26 (Air concentration in room 2 with source in room 1 ) } \\
\hline Volume & $2.8 \mathrm{E}-07$ & $2.77 \mathrm{E}-07$ & $2.8 \mathrm{E}-09$ & $2.80 \mathrm{E}-09$ & 2.9E-04 & $2.95 \mathrm{E}-04$ \\
\hline Area & $6.6 \mathrm{E}-07$ & $6.59 \mathrm{E}-07$ & $1.6 \mathrm{E}-08$ & $1.60 \mathrm{E}-08$ & 4.2E-08 & $4.20 \mathrm{E}-08$ \\
\hline Line & $6.6 \mathrm{E}-07$ & $6.59 \mathrm{E}-07$ & $1.6 \mathrm{E}-08$ & $1.60 \mathrm{E}-08$ & $4.2 \mathrm{E}-08$ & $4.20 \mathrm{E}-08$ \\
\hline Point & $1.8 \mathrm{E}-08$ & $1.83 \mathrm{E}-08$ & 4.4E-09 & 4.43E-09 & $1.2 \mathrm{E}-10$ & $1.17 \mathrm{E}-10$ \\
\hline
\end{tabular}

calculated values of the air concentration for the three sets of parameters (default, lower bound, and upper bound) for the two-room air quality model. The diag.out files for cases 4, 5, and 6 in the Appendix include the air concentrations for four source types generated by the RESRADBUILD code for the two-room air quality model. Again, as shown in Table 4.2, excellent agreement was obtained between the code output and the spreadsheet calculations for the Na-22 and Al-26 radionuclides at time zero.

The air particulate deposition model in RESRAD-BUILD evaluates the surface contamination, $C_{d i}^{n}$, due to deposition of the principal radionuclide of order $n$ in the decay series, in each compartment, $i$, of the building, as a function of the respective airborne concentration in 
that compartment. Assuming a steady-state condition, the surface contamination can be given as (Equation B.3 in the RESRAD-BUILD manual):

$$
C_{d i}^{n}=\left(\frac{u_{d}}{\lambda_{r n}+\lambda_{R}}\right) C_{i}^{n}
$$

Equation 4.13 was used to calculate the air particulate deposition in each compartment as a function of the respective air concentration. Figure 4.5 shows the calculated air particulate deposition for the default parameter set for the one- and two-room air quality models. The surface particle contamination due to deposition was used in calculating the inadvertent ingestion pathway dose directly from the deposited materials and the external exposure pathway dose (Sections 8.3 and 8.7, respectively). 


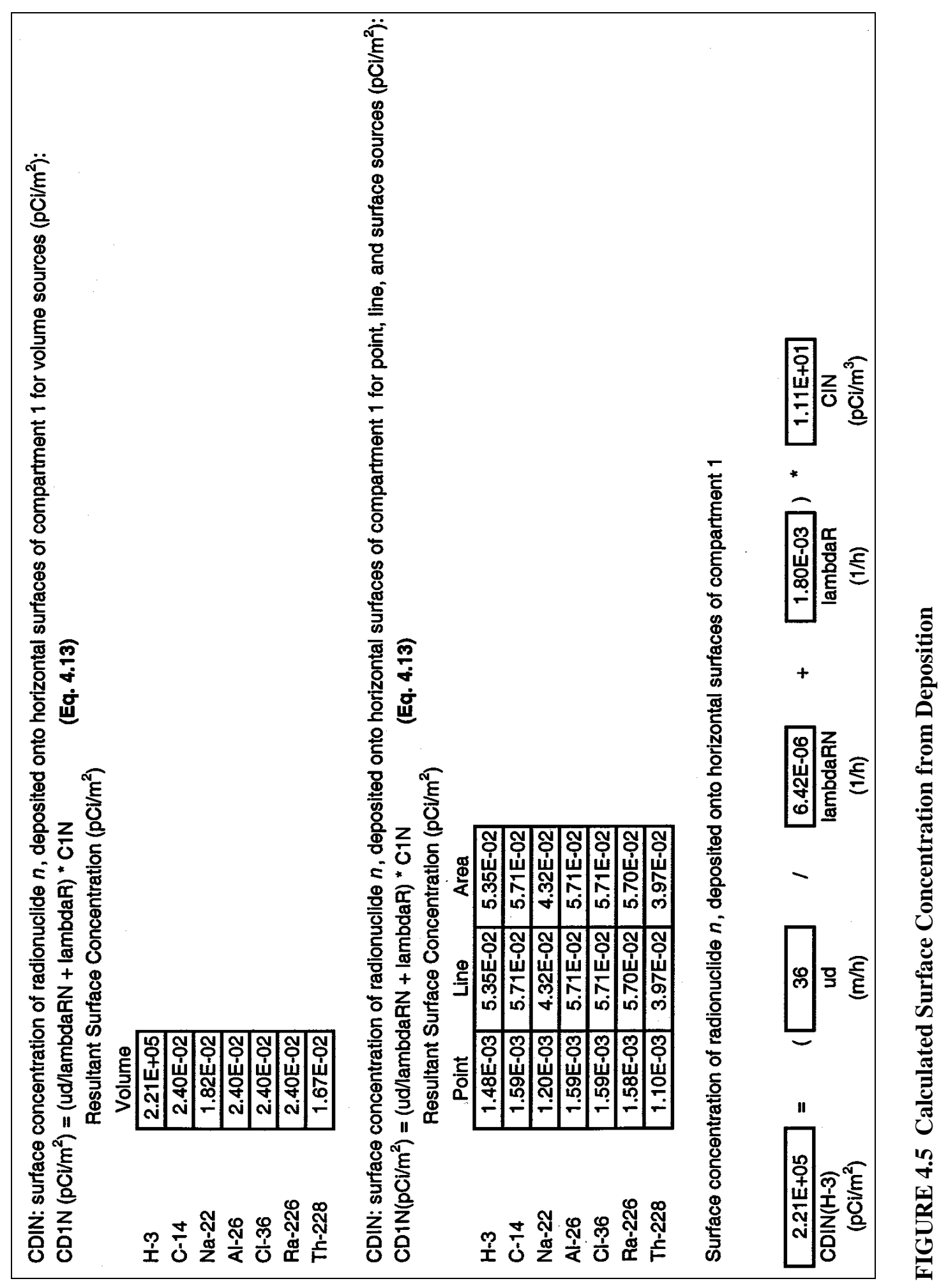




\section{RADON PATHWAY MODEL}

The radon pathway dose estimation involved the following four calculations:

1. The indoor air concentration of radon and its decay products;

2. The working level (WL) based on the values of air concentrations;

3. The exposure in working level month (WLM) to the radon decay products, based on the WL and exposure duration; and

4. The effective dose equivalent based on the WL and the related DCFs.

The indoor radon concentration in the indoor air of compartment $i$ was calculated by using the air quality model. To apply the air quality model, the radon injection rate was evaluated. The airborne concentration of radon progeny was then calculated sequentially by applying the mass balance equations.

The $W L_{i}$ value in compartment $i$ for an indoor atmosphere containing a mixture of radon (Rn-222) progeny was evaluated as (Yu et al. 1994, Equation C.32):

$$
W L_{i}^{R n-222}=\left(1.03 \times 10^{-6}\right) C_{i}^{2}+\left(5.07 \times 10^{-6}\right) C_{i}^{3}+\left(3.73 \times 10^{-6}\right) C_{i}^{4},
$$

where $C_{i}^{2}, C_{i}^{3}$, and $C_{i}^{4}$ are the concentrations of Po-218, $\mathrm{Pb}-214$, and Bi-214, respectively, in the indoor air of compartment $i\left(\mathrm{pCi} / \mathrm{m}^{3}\right)$. Similarly, for thoron $(\mathrm{Rn}-220)$, the $W L_{i}$ value was evaluated as (Yu et al. 1994, Equation C.33):

$$
W L_{i}^{R n-220}=\left(9.48 \times 10^{-10}\right) C_{i}^{\prime 2}+\left(1.23 \times 10^{-4}\right) C_{i}^{\prime 3}+\left(1.17 \times 10^{-5}\right) C_{i}^{\prime 4},
$$

where $C_{i}^{\prime 2}, C_{i}^{\prime 3}$, and $C_{i}^{\prime 4}$ are the concentrations of Po-216, Pb-212, and Bi-212, respectively, in the indoor air of compartment $i\left(\mathrm{pCi} / \mathrm{m}^{3}\right)$.

The radon progeny concentration is measured in units of WLMs, which for each compartment $i$ can be calculated as (Yu et al., 1994, Equation C.34):

$$
W L M_{i}=\left(\frac{8,760}{170}\right) F_{i n} F_{i} W L_{i},
$$

where 
$8,760=$ number of hours per year $(\mathrm{h} / \mathrm{yr})$, and

$170=$ number of working hours per month $(\mathrm{h})$.

The effective dose equivalent due to the exposure to radon decay products in the indoor air of each compartment $i$ can be evaluated as (Yu et al. 1994, Equation C.37):

$$
D_{i}=K W L M_{i} D C F,
$$

where

$$
\begin{aligned}
& D_{i}=\text { effective dose equivalent due to exposure to radon decay products (from } \\
& \text { either Rn-222 or Rn-220) in compartment } i(\mathrm{mrem} / \mathrm{yr}) \text {; } \\
& D C F=\text { dose conversion factor for the inhalation of radon decay products } \\
& \text { (mrem/WLM); and } \\
& K=\text { multiplication factor to account for the extrapolation of doses from } \\
& \text { uranium mines to homes. }
\end{aligned}
$$

For the Rn-222 decay products, the values of the $D C F$ and the $K$ factor are equal to 1,000 (mrem/WLM) and 0.76 (dimensionless), respectively. Similarly, for the Rn-220 decay products, the values of the $D C F$ and the $K$ factor are equal to $350(\mathrm{mrem} / \mathrm{WLM})$ and 0.42 (dimensionless), respectively. The values of the $D C F$ and the $K$ factor for the Rn-222 and $\mathrm{Rn}-220$ decay products are consistent with those used in RESRAD.

\subsection{RADON INJECTION RATE}

The rate of radon injection into the indoor air depends on the concentration of the radon parent within the source and on the geometric and physical properties of the source. Therefore, the injection rate $\left(I_{S i}^{R i}\right)$ is defined for each type of source: surface, line, point, and volume. For surface, line, and point sources, $I_{S i}^{R n}(\mathrm{pCi} / \mathrm{s})$ is calculated as (Yu et al. 1994, Equation C.1):

$$
I_{S i}^{R n}=F^{R n} \lambda A_{\text {total }}^{p},
$$


where

$$
\begin{aligned}
F^{R n}= & \text { fraction of radon generated within the source that escapes from the } \\
& \text { source and is injected into the air (dimensionless), } \\
\lambda= & \text { radon decay constant }\left(\mathrm{s}^{-1}\right), \text { and } \\
A_{\text {total }}^{p}= & \text { total amount of the radon parent radionuclide present within the source } \\
& (\mathrm{pCi}) .
\end{aligned}
$$

For a volume source, the radon injection rate, $I_{S i}^{R n}$, is evaluated differently, according to the following (Yu et al. 1994, Equation C.2):

$$
I_{S i}^{R n}=A_{s} J,
$$

where

$$
\begin{aligned}
A_{S}= & \text { surface area of the face of the volume source that is exposed to the indoor } \\
& \text { air of compartment } i\left(\mathrm{~m}^{2}\right), \text { and } \\
J= & \text { flux density of radon activity (or radon flux, for short) through the exposed } \\
& \text { face of the volume source }\left(\mathrm{pCi} \times \mathrm{m}^{-2} \times \mathrm{s}^{-1}\right) .
\end{aligned}
$$

The variables $F^{R n}$ and $A_{\text {total }}^{p}$ are given as input parameters to the model. Therefore, the calculation of $I_{S i}^{R n}$ for surface, line, and point sources is a straightforward procedure, based directly on Equation 5.5. For volume sources, the radon flux is not given as an input parameter and must be evaluated specifically for each case. Appendix C of the RESRAD-BUILD manual describes how the radon flux is calculated. Figure 5.1 shows the radon flux calculations for a volume source using all default parameters. The radon injection rates are printed in a detailed report titled diag.out after the calculations are completed. The diag.out files for cases 7, 8, and 9 in the Appendix include the radon injection rates generated by the RESRAD-BUILD code for point and volume sources of Ra-226 and Th-228 contamination. Table 5.1 presents a comparison of the spreadsheet calculated values of Ra-226, Th-228, Rn-222, and Rn-220 injection rates for point and volume sources with the RESRAD-BUILD code generated values. Since the method used for point, line, and area sources is the same, only point source values were compared. Figure 5.2 shows the spreadsheet calculations for point and volume sources. The values for the Ra-226 and Th-228 injection rates for a volume and point source are from Figure 3.1. The unit conversion from hour to second was applied. For the point source, there was no difference in the RESRAD-BUILD and spreadsheet calculations. However, the volume source injection rates for $\mathrm{Rn}-222$ and $\mathrm{Rn}-220$ were different in two cases. The difference is due to the density used in the calculations. For the spreadsheet calculations, it was assumed that the particle density is input; 


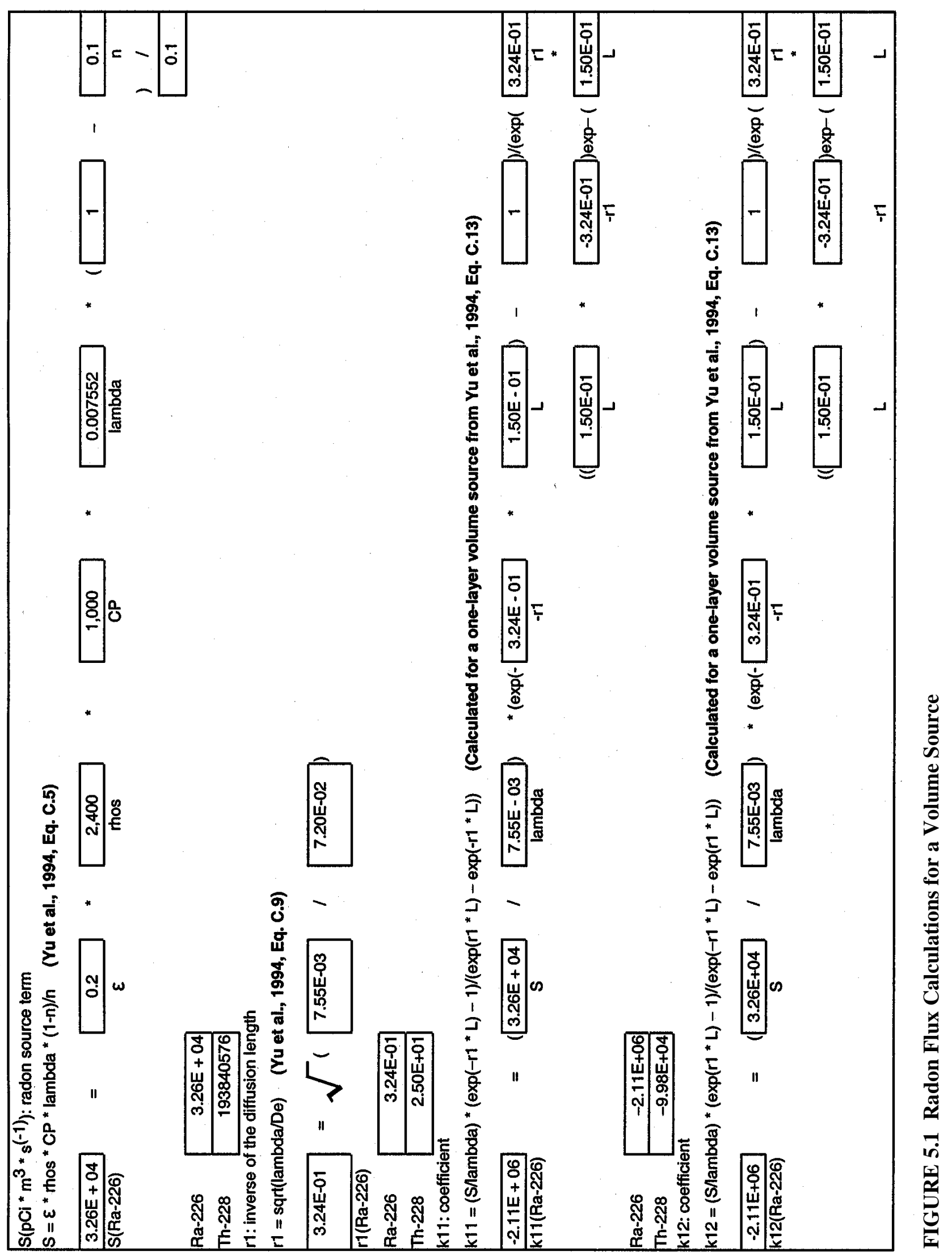




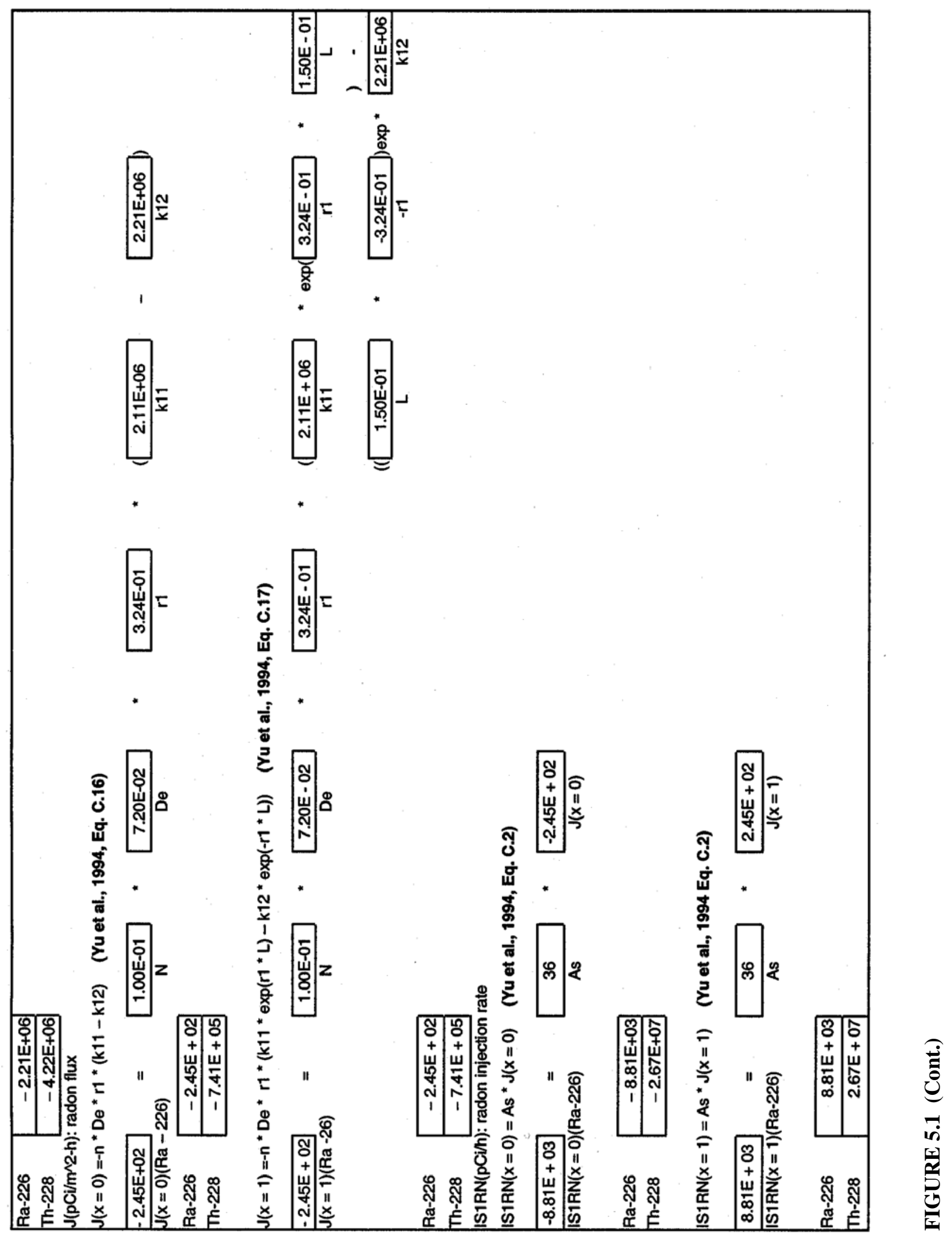


TABLE 5.1 RESRAD-BUILD and Spreadsheet Injection Rates (pCi/s) for Ra-226 and Th-228 Point and Volume Sources for Three Sets of Input Parameters

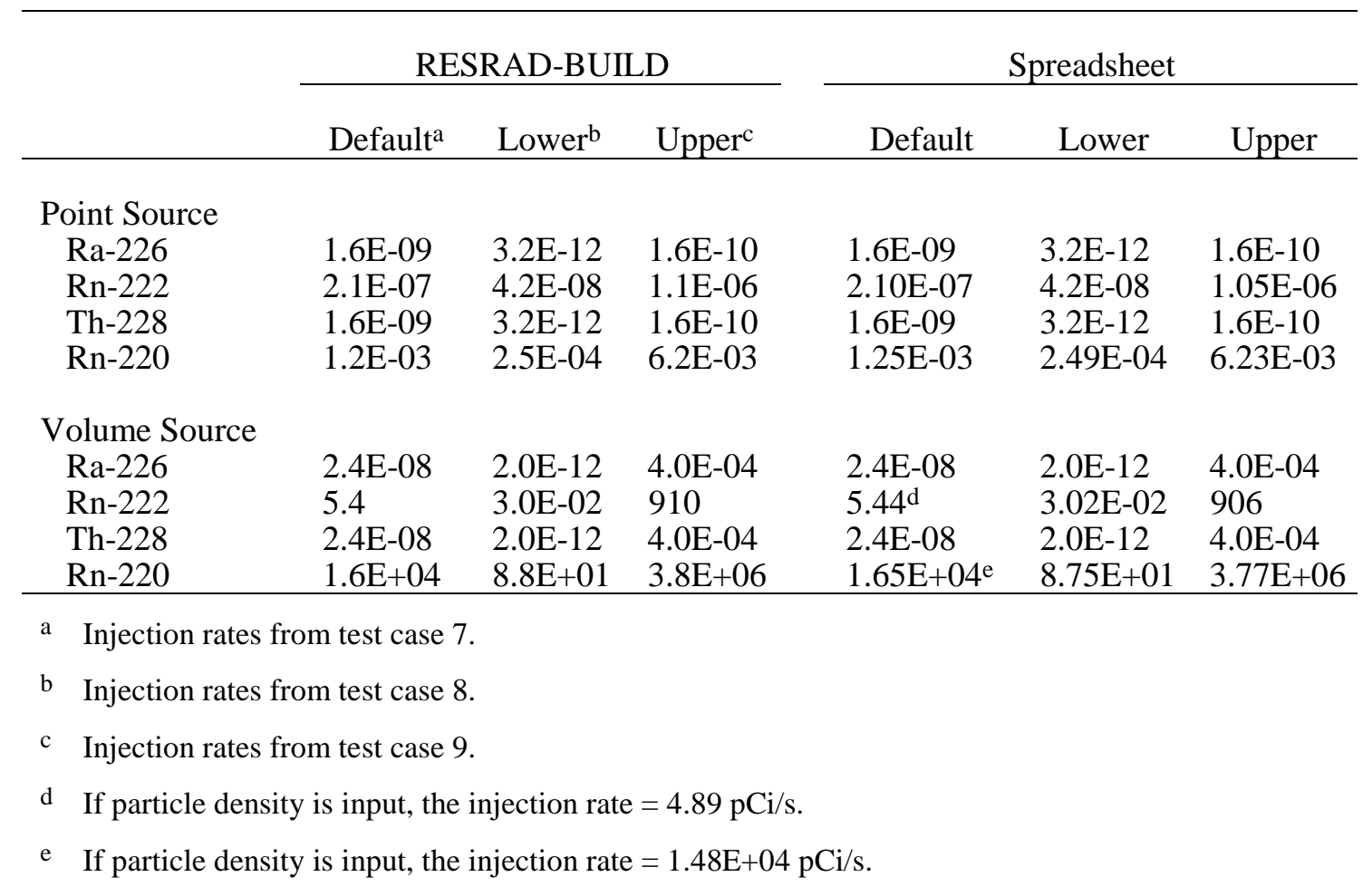

whereas in RESRAD-BUILD, the source bulk density was assumed. If the density is changed in the spreadsheet, the results are the same (within round-off errors) as the RESRAD-BUILD code output.

\subsection{RADON PROGENY CONCENTRATION}

The radon progeny concentrations are also printed in the diag.out file after the calculations are completed. The calculated values of the Ra-226 and Th-228 progeny concentrations for a point and volume source were compared with the RESRAD-BUILD values (test cases 7, 8, and 9) in Table 5.2. Since the methods used for a point, line, and area source are the same, only point source values were compared. Figure 5.3 shows the spreadsheet calculations of the radon progeny concentrations for the default parameter sets for a point source. Equations used in calculating progeny concentrations were from the RESRAD-BUILD manual (Equations C.18 - C.31).

The radon decay products may exist in the free (fr), attached (at), or plate-out (po) state. Figure 5.3 shows the air concentration of the decay products in these states (free, attached, and plate-out). The values of the rate constants and the probability of attachment used in the 


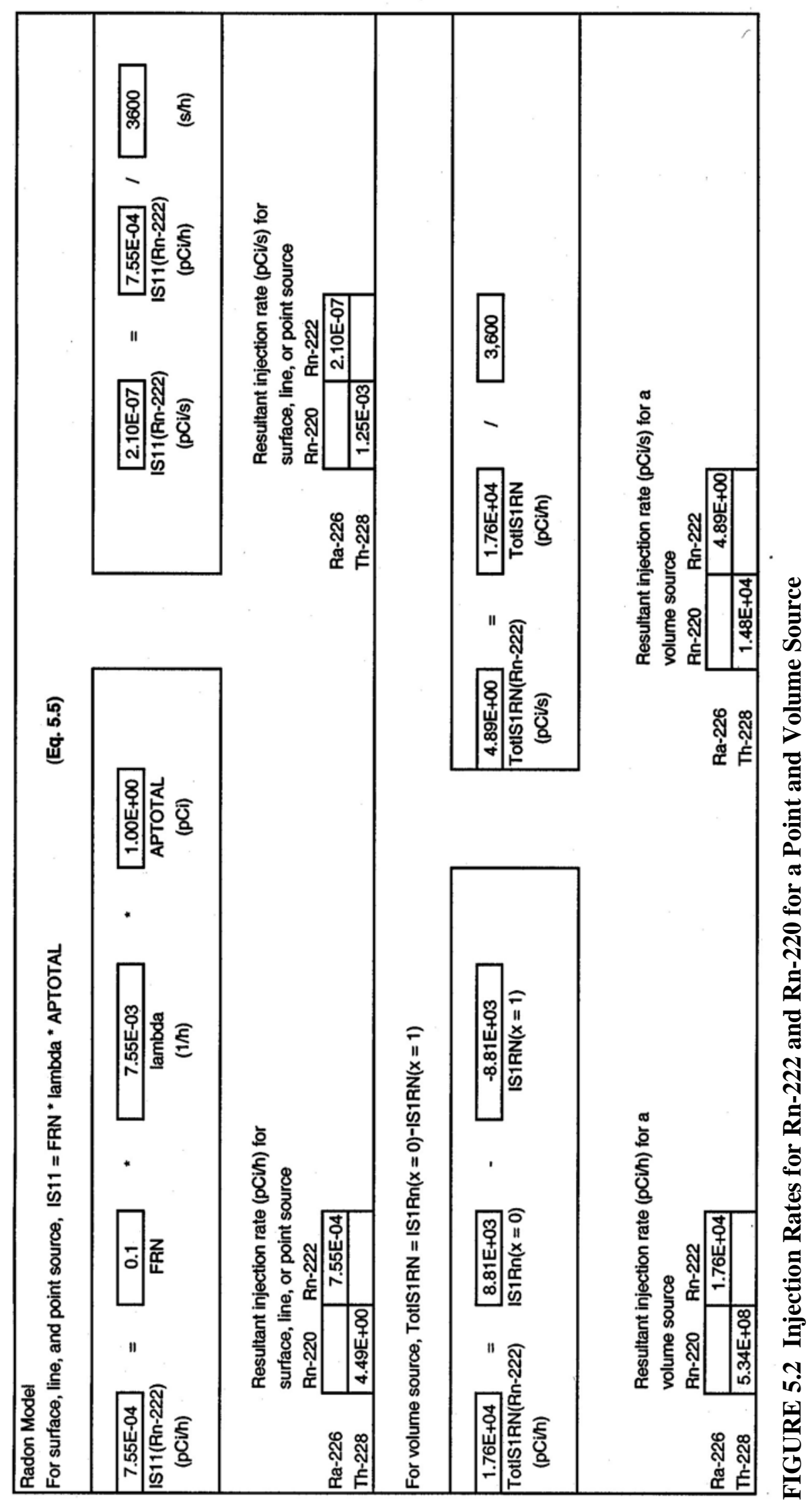


TABLE 5.2 RESRAD-BUILD and Spreadsheet Air Concentrations (pCi/m $\mathbf{m}^{3}$ ) for Ra-226 and Th-228 and Their Progeny for Three Sets of Input Parameters

\begin{tabular}{|c|c|c|c|c|c|c|}
\hline & \multicolumn{3}{|c|}{ RESRAD-BUILD } & \multicolumn{3}{|c|}{ Spreadsheet } \\
\hline & Default ${ }^{\mathrm{a}}$ & Lower ${ }^{b}$ & Upperc & Default & Lower & Upper \\
\hline \multicolumn{7}{|c|}{ Point Source } \\
\hline Ra-226 & 7.9E-08 & $1.1 \mathrm{E}-08$ & $2.8 \mathrm{E}-10$ & 7.92E-08 & $1.05 \mathrm{E}-08$ & $2.82 \mathrm{E}-10$ \\
\hline Rn-222 & $1.0 \mathrm{E}-05$ & 1.3E-04 & $1.9 \mathrm{E}-06$ & $1.04 \mathrm{E}-05$ & $1.34 \mathrm{E}-04$ & $1.86 \mathrm{E}-06$ \\
\hline Po-218 & $2.9 \mathrm{E}-06$ & 7.0E-05 & $6.1 \mathrm{E}-07$ & 2.92E-06 & 7.01E-05 & $6.06 \mathrm{E}-07$ \\
\hline $\mathrm{Pb}-214$ & 2.7E-07 & $5.3 \mathrm{E}-05$ & $1.1 \mathrm{E}-07$ & $2.65 \mathrm{E}-07$ & $5.26 \mathrm{E}-05$ & $1.07 \mathrm{E}-07$ \\
\hline Bi-214 & $3.1 \mathrm{E}-08$ & $4.8 \mathrm{E}-05$ & 2.4E-08 & $3.12 \mathrm{E}-08$ & 4.83E-05 & $2.37 \mathrm{E}-08$ \\
\hline Th-228 & 5.6E-08 & $1.1 \mathrm{E}-08$ & $2.8 \mathrm{E}-10$ & $5.65 \mathrm{E}-08$ & $1.05 \mathrm{E}-08$ & $2.82 \mathrm{E}-10$ \\
\hline Rn-220 & $1.1 \mathrm{E}-03$ & $3.3 \mathrm{E}-03$ & 3.6E-04 & $1.09 \mathrm{E}-03$ & $3.31 \mathrm{E}-03$ & $3.58 \mathrm{E}-04$ \\
\hline Po-216 & $1.1 \mathrm{E}-03$ & $3.3 \mathrm{E}-03$ & $3.6 \mathrm{E}-04$ & $1.09 \mathrm{E}-03$ & $3.31 \mathrm{E}-03$ & $3.58 \mathrm{E}-04$ \\
\hline $\mathrm{Pb}-212$ & 2.7E-06 & 4.4E-04 & 5.9E-06 & $2.70 \mathrm{E}-06$ & $4.40 \mathrm{E}-04$ & $5.95 \mathrm{E}-06$ \\
\hline $\mathrm{Bi}-212$ & $1.1 \mathrm{E}-07$ & $3.5 \mathrm{E}-04$ & 7.7E-07 & $1.11 \mathrm{E}-07$ & $3.48 \mathrm{E}-04$ & 7.66E-07 \\
\hline \multicolumn{7}{|c|}{ Volume Source } \\
\hline Ra-226 & $1.2 \mathrm{E}-06$ & 6.7E-09 & $7.1 \mathrm{E}-04$ & $1.20 \mathrm{E}-06$ & $6.65 \mathrm{E}-09$ & $7.11 \mathrm{E}-04$ \\
\hline $\mathrm{Rn}-222$ & 270 & 97 & 1600 & 269 & 96.4 & 1600 \\
\hline Po-218 & 76 & 50 & 520 & 75.6 & 50.4 & 523 \\
\hline $\mathrm{Pb}-214$ & 6.9 & 38 & 92 & 6.86 & 37.8 & 92.2 \\
\hline Bi-214 & 0.80 & 35 & 20 & 0.809 & 34.7 & 20.5 \\
\hline Th-228 & $8.5 \mathrm{E}-07$ & 6.7E-09 & 7.1E-04 & $8.55 \mathrm{E}-07$ & $6.65 \mathrm{E}-09$ & $7.11 \mathrm{E}-04$ \\
\hline $\mathrm{Rn}-220$ & $1.4 \mathrm{E}+04$ & $1.2 \mathrm{E}+03$ & $2.2 \mathrm{E}+05$ & $1.44 \mathrm{E}+04$ & $1.16 \mathrm{E}+03$ & $2.17 \mathrm{E}+05$ \\
\hline Po-216 & $1.4 \mathrm{E}+04$ & $1.2 \mathrm{E}+03$ & $2.2 \mathrm{E}+05$ & $1.44 \mathrm{E}+04$ & $1.16 \mathrm{E}+03$ & $2.17 \mathrm{E}+05$ \\
\hline $\mathrm{Pb}-212$ & 36 & 150 & $3.6 \mathrm{E}+03$ & 35.7 & 154 & $3.60 \mathrm{E}+03$ \\
\hline Bi-212 & 1.5 & 120 & 460 & 1.46 & 122 & 463 \\
\hline
\end{tabular}

a Air concentrations from test case 7.

b Air concentrations from test case 8 .

c Air concentrations from test case 9.

calculations were taken from the RESRAD-BUILD manual (Appendix C, Table C.1). The airborne concentration of each radon decay product was then calculated as the sum of the respective concentrations in the free and attached state.

Table 5.2 provides the RESRAD-BUILD and spreadsheet calculated values of the air concentration for the three sets of parameters (default, lower bound, and upper bound) for the one-room air quality model. The air concentrations for Ra-226 and Th-228 are from Figure 4.1. For calculating air concentrations, density differences were taken into consideration. No significant differences in the RESRAD-BUILD and spreadsheet calculations were observed. 


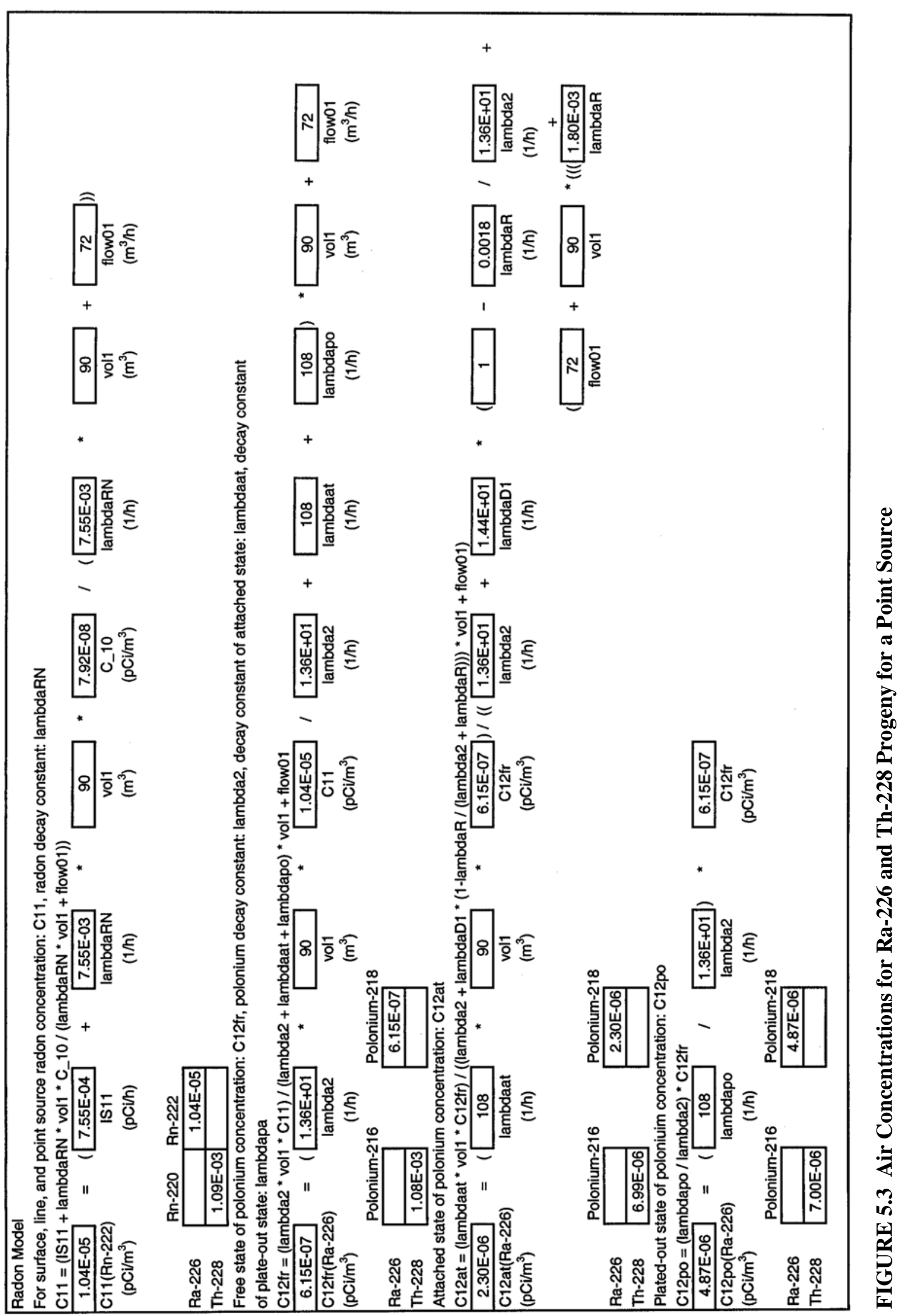




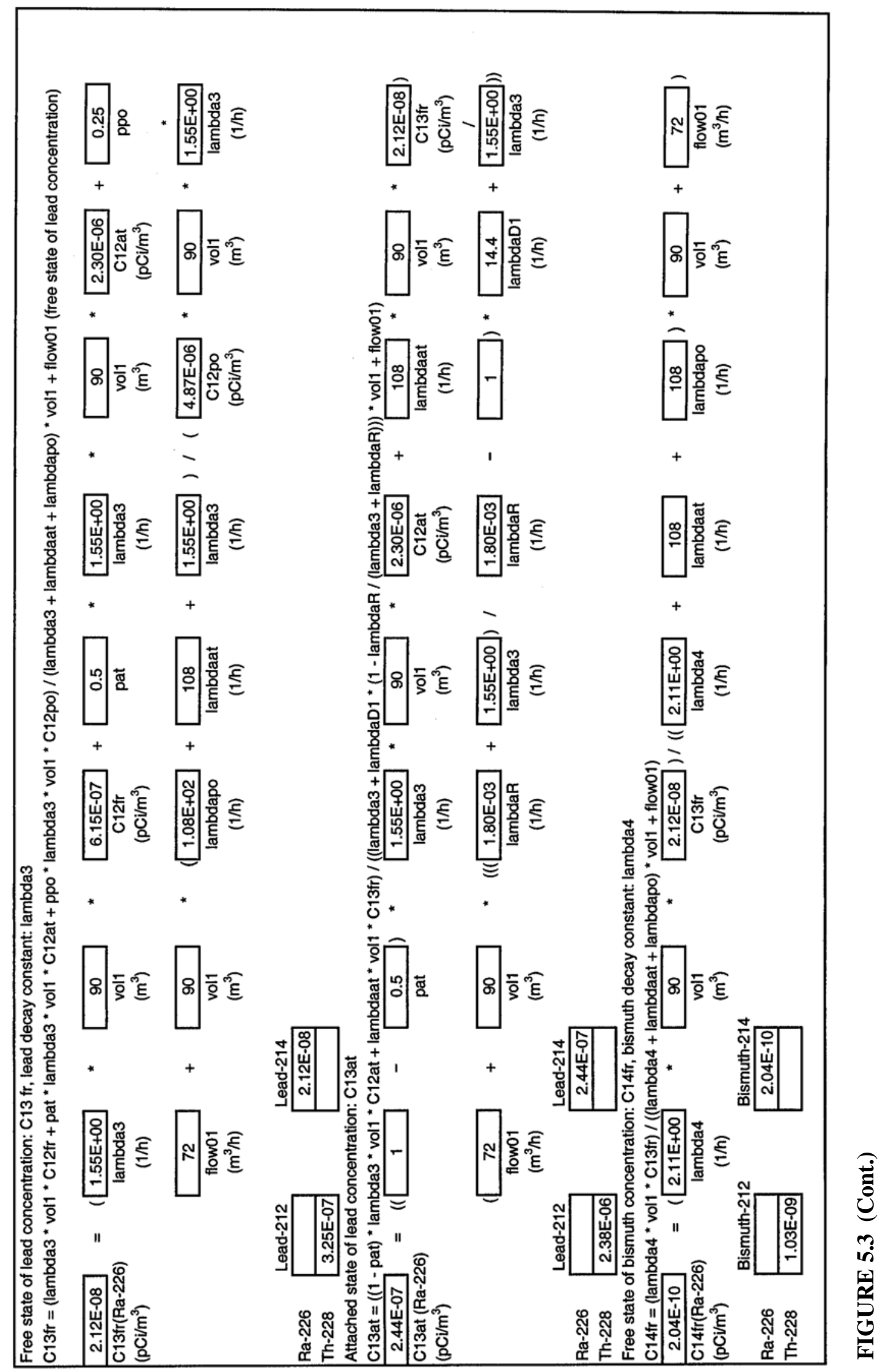




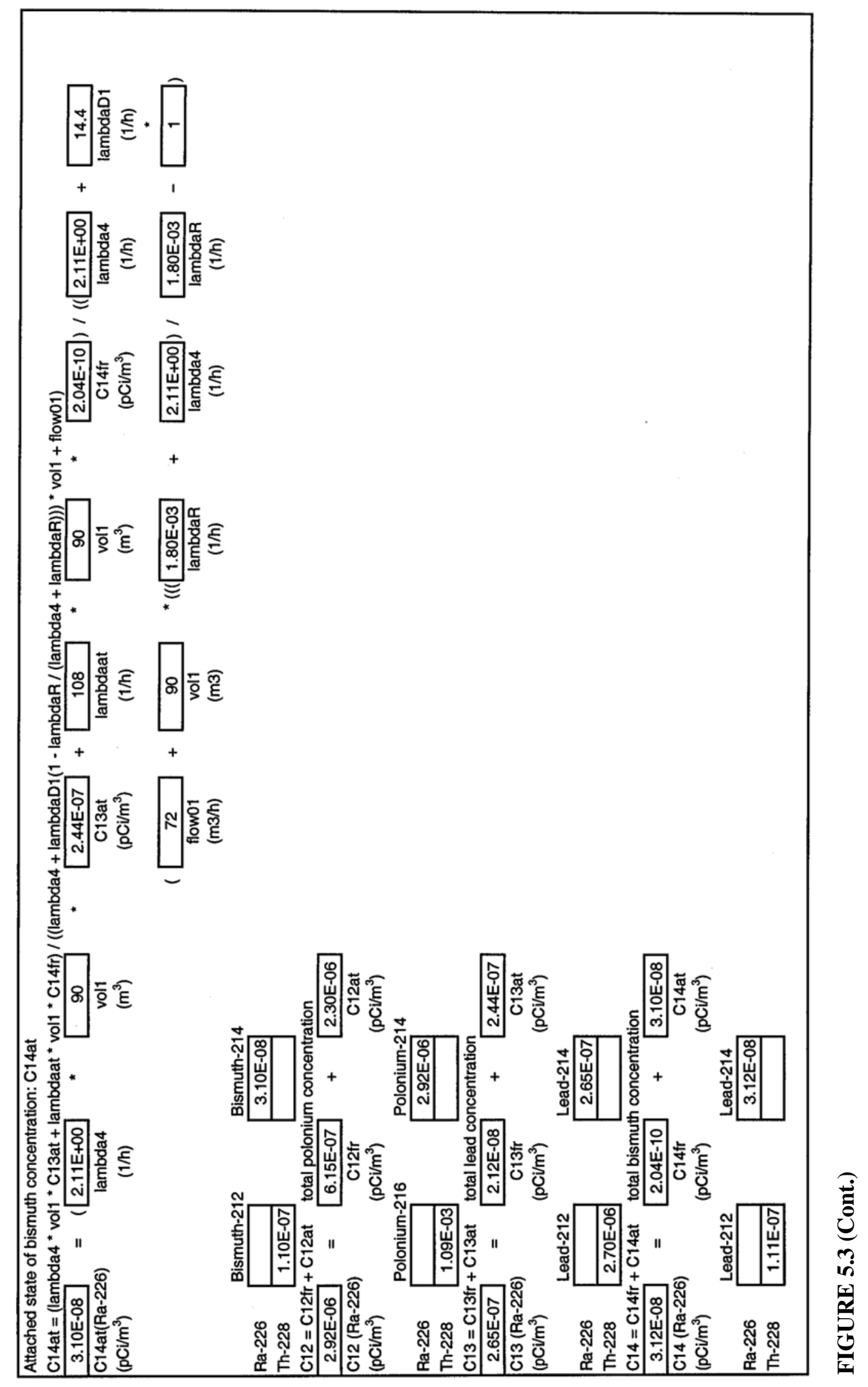




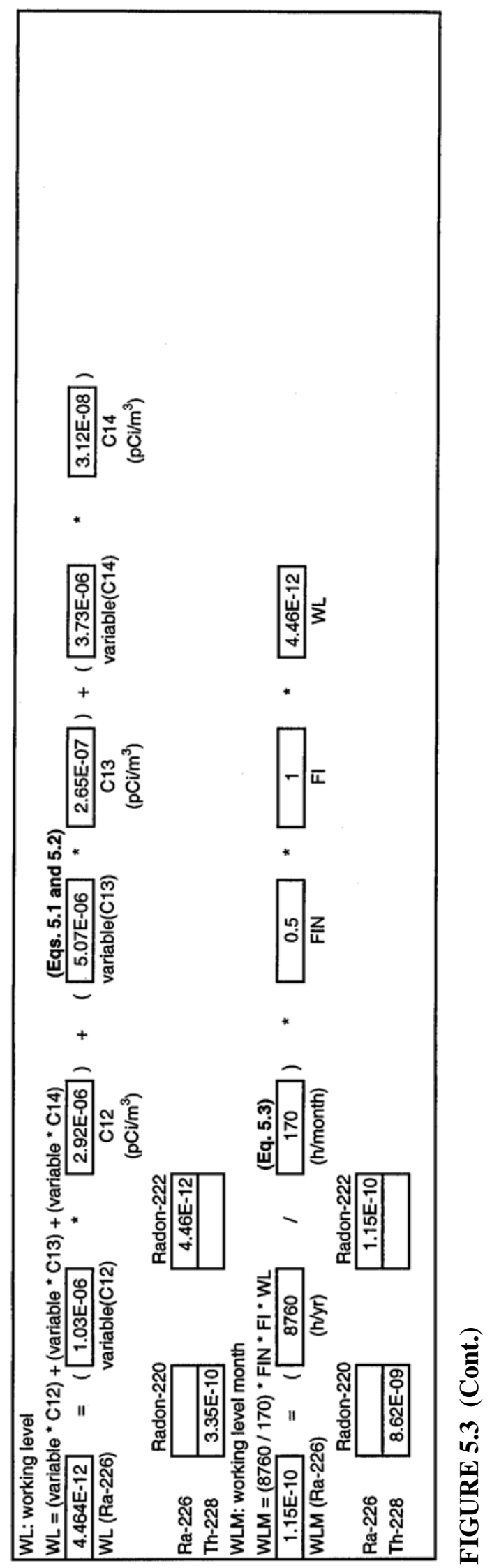




\section{TRITIUM MODEL FOR VOLUME SOURCE}

Tritium contamination requires special consideration, because in addition to erosion, tritium, which most often is in the chemical form of tritiated water (HTO), can vaporize and escape from the source material. The potential release of tritium from a volume source would occur through erosion and, if in the form of HTO, vaporization. The total release rate is the sum of the releases from erosion and vaporization. The total release rate is then used to calculate the inhalation pathway dose for a tritium volume source. The release rate from erosion is the same as Equation 3.1 for other radionuclides but is modified by a fraction $\left(1-f_{\text {rel }}\right)$, where $f_{\text {rel }}$ is the fraction of tritium available for vaporization. For tritium in a chemical form other than HTO, which is assumed to be released by absorbing or adsorbing to the source material and not by vaporization, the value of $f_{r e l}$ would be zero. Similarly, direct ingestion pathway doses would be modified by $\left(1-f_{\text {rel }}\right)$.

The tritium transport model in RESRAD-BUILD, which was adapted from the landfarming model developed by Thibodeaux and Hwang (1988) estimates the injection rate of HTO molecules into the indoor air from vaporization. The model assumes that the water containing HTO may penetrate into the building walls or floor or equipment and be distributed homogeneously within a depth of $h(\mathrm{~cm})$ to $h_{p}(\mathrm{~cm})$ from the surface within the material. The region where the water is distributed is called the wet zone; the dry zone is the region between the wet zone and the air interface. To calculate the release rate of tritium, $q_{\mathrm{H} 3}$, at any time from vaporization into the air, the water diffusion rate, $q_{\text {water }}$, at that time needs to be multiplied by the activity concentration of tritium in water, $A_{\mathrm{H} 3}$, and radiological decay. The release $q_{\mathrm{H} 3}$ can be given as:

$$
q_{\mathrm{H} 3}=3,600 A_{\mathrm{H} 3} e^{-\lambda t^{\prime}} q_{\text {water }},
$$

where

$$
\begin{aligned}
q_{\mathrm{H} 3} & =\text { release rate of tritium at time } t^{\prime}(\mathrm{pCi} / \mathrm{h}), \\
A_{\mathrm{H} 3} & =\text { activity concentration of tritium in water at time zero }(\mathrm{pCi} / \mathrm{g}), \\
\lambda & =\text { radiological decay constant of tritium }(1 / \mathrm{yr}), \\
t^{\prime} & =\text { elapsed time since the beginning of the vaporization process }(\mathrm{yr}), \text { and } \\
3,600 & =\text { conversion factor of time }(\mathrm{s} / \mathrm{h}) .
\end{aligned}
$$

The activity concentration of tritium in water is related to the activity concentration of tritium in the contaminated zone as: 


$$
A_{\mathrm{H} 3}=C_{\mathrm{H} 3}\left(1+\frac{\rho_{b}}{\rho_{\text {water }} W}\right),
$$

where

$$
\begin{aligned}
C_{\mathrm{H} 3}= & \text { activity concentration of tritium in the contaminated zone }(\mathrm{pCi} / \mathrm{g}), \\
\rho_{b}= & \text { bulk density of the porous material }\left(\mathrm{g} / \mathrm{cm}^{3}\right), \\
W= & \text { moisture content (volumetric water content) in the wet zone (dimension- } \\
& \text { less), and } \\
\rho_{\text {water }}= & \text { density of water }\left(\mathrm{g} / \mathrm{cm}^{3}\right) .
\end{aligned}
$$

Under the steady-state assumption, the vaporization rate from the wet zone is equivalent to the diffusion rate from the dry zone and is given as:

$$
q_{\text {water }}=\frac{D_{e} C_{g}^{\prime} A_{S}}{\sqrt{h_{s}^{2}+\frac{2 D_{e} C_{g}^{\prime} t^{\prime} f_{\text {time }}}{C_{s} f_{\text {rel }}}}}
$$

where

$$
\begin{aligned}
f_{\text {time }}= & \text { conversion factor }(31,557,600 \mathrm{~s} / \mathrm{yr}), \\
C_{s}= & \text { mass concentration of water in the wet zone }\left(\mathrm{g} / \mathrm{cm}^{3}\right), \\
C_{g}^{\prime}= & \begin{array}{l}
\text { concentration of water molecules in the vapor phase of the source material } \\
\left(\mathrm{g} / \mathrm{cm}^{3}\right),
\end{array} \\
h_{s}= & \text { dry zone thickness at the beginning of time }(t=0)(\mathrm{cm}), \\
D_{e}= & \begin{array}{l}
\text { effective diffusion coefficient of water molecules in the source material } \\
(\mathrm{cm} / \mathrm{s}), \text { and }
\end{array} \\
A_{s}= & \text { surface area of the source }\left(\mathrm{cm}^{2}\right) .
\end{aligned}
$$




$$
C_{g}^{\prime}=\left(C_{g}-C_{g, a m b}\right),
$$

where

$$
\begin{aligned}
& C_{g}=\text { concentration of water vapor in the void space of the wet zone }\left(\mathrm{g} / \mathrm{cm}^{3}\right) \text { and } \\
& C_{g, a m b}=\text { absolute humidity in the air }\left(\mathrm{g} / \mathrm{cm}^{3}\right) . \\
& \qquad D_{e}=D_{i} n^{\frac{4}{3}}
\end{aligned}
$$

where

$$
\begin{aligned}
& n=\text { total porosity and } \\
& D_{I}=\text { air diffusion coefficient }\left(0.2444 \mathrm{~cm}^{2} / \mathrm{s}\right) . \\
& \qquad C_{g}=\frac{P_{s a t} M W}{R T},
\end{aligned}
$$

where

$$
\begin{aligned}
M W & =\text { molecular weight of water }(18 \mathrm{~g} / \mathrm{mol}), \\
R & =\text { the gas constant }\left[82\left(\operatorname{atm} \times \mathrm{cm}^{3}\right) / \mathrm{mol} \times \mathrm{K}\right], \\
T & =\text { room temperature }(298 \mathrm{~K}), \text { and } \\
P_{\text {sat }} & =\text { saturated vapor pressure of water }(0.0245 \mathrm{~atm}) .
\end{aligned}
$$

The RESRAD-BUILD tritium model estimates the average release rate of tritium over a certain time period. The time period is the smallest of three: one year, exposure duration, or the time required for the remaining free water to vaporize. The time required for the remaining free water in the wet zone to vaporize depends on the thickness of the dry zone $(h)$ (a layer on top of the wet zone) and the wet zone $\left(h_{\mathrm{p}}-h\right)$. The dry zone can be considered as a layer without any $\mathrm{H}-3$ concentration, and the wet zone is where $\mathrm{H}-3$ is available for vaporization. According to Fick's law, the diffusion rate of $\mathrm{H}_{2} \mathrm{O}$ molecules through the dry zone can be expressed as:

$$
q_{\text {water }}=\frac{D_{e}\left(C_{g}-C_{g, a m b}\right)}{h} A_{s} .
$$


Under steady-state conditions, the vaporization rate from the wet zone is equivalent to the diffusion rate through the dry zone. Therefore,

$$
q_{\text {water }}=A_{s} C_{s} f_{r e l} \frac{d h}{d t}
$$

Using Equations 6.8 and 6.9, the dry zone thickness at any time $t$ can be calculated by the following equation:

$$
h=\sqrt{h_{s}^{2}+\frac{2 D_{e}\left(C_{g}-C_{g, a m b}\right) t}{C_{s} f_{r e l}}} .
$$

The time required for the remaining free water in the wet zone to vaporize, $t_{d}$, can be calculated after setting $h$ to $h p$ and $h s$ to $h$ in Equation 6.10 as:

$$
t_{d}=\frac{C_{S}\left(h_{p}^{2}-h^{2}\right) f_{r e l}}{2 D_{e} C_{g}^{\prime}} .
$$

The Newton-Cotes open integration method is used to estimate the average release rate of tritium. Five equally spaced time points are selected over the time period $\left(t_{\text {period }}\right)$ for which the instantaneous release rate of tritium is estimated. The average release rate is then obtained by summing the weighted spontaneous release rates for the five time points, as represented by the following equation:

$$
q_{\mathrm{H} 3, a v g}=\frac{11 q_{\mathrm{H} 3}^{1}-14 q_{\mathrm{H} 3}^{2}+26 q_{\mathrm{H} 3}^{3}-14 q_{\mathrm{H} 3}^{4}-11 q_{\mathrm{H} 3}^{5}}{20},
$$

where

$$
\begin{aligned}
q_{\mathrm{H} 3, \text { avg }}= & \begin{array}{l}
\text { average release rate of tritium over the time period } \\
(\mathrm{pCi} / \mathrm{yr}),
\end{array} \\
t_{\text {period }}= & \text { time period }(\mathrm{yr}), \\
q_{\mathrm{H} 3}^{1}, q_{\mathrm{H} 3}^{2}, q_{\mathrm{H} 3}^{3}, q_{\mathrm{H} 3}^{4}, q_{\mathrm{H} 3}^{5}= & \begin{array}{l}
\text { instantaneous tritium release rates at time points } t^{1}, \\
t^{2}, t^{3}, t^{4}, t^{5}, \text { respectively, and }
\end{array} \\
t^{1}, t^{2}, t^{3}, t^{4}, t^{5}= & \begin{array}{l}
\text { selected time points for estimating the } \\
\text { instantaneous release rate, evenly distributed } \\
\text { between } t \text { and } t+t_{\text {period }} .
\end{array}
\end{aligned}
$$


Figure 6.1 shows all tritium-model parameters required for a volume source and the calculation of the average tritium release rate. The average tritium release rate calculated from vaporization is added to the release rate from the source erosion for a volume source (Equation 3.1) to calculate the inhalation pathway dose for the tritium volume source (Section 8.8). 


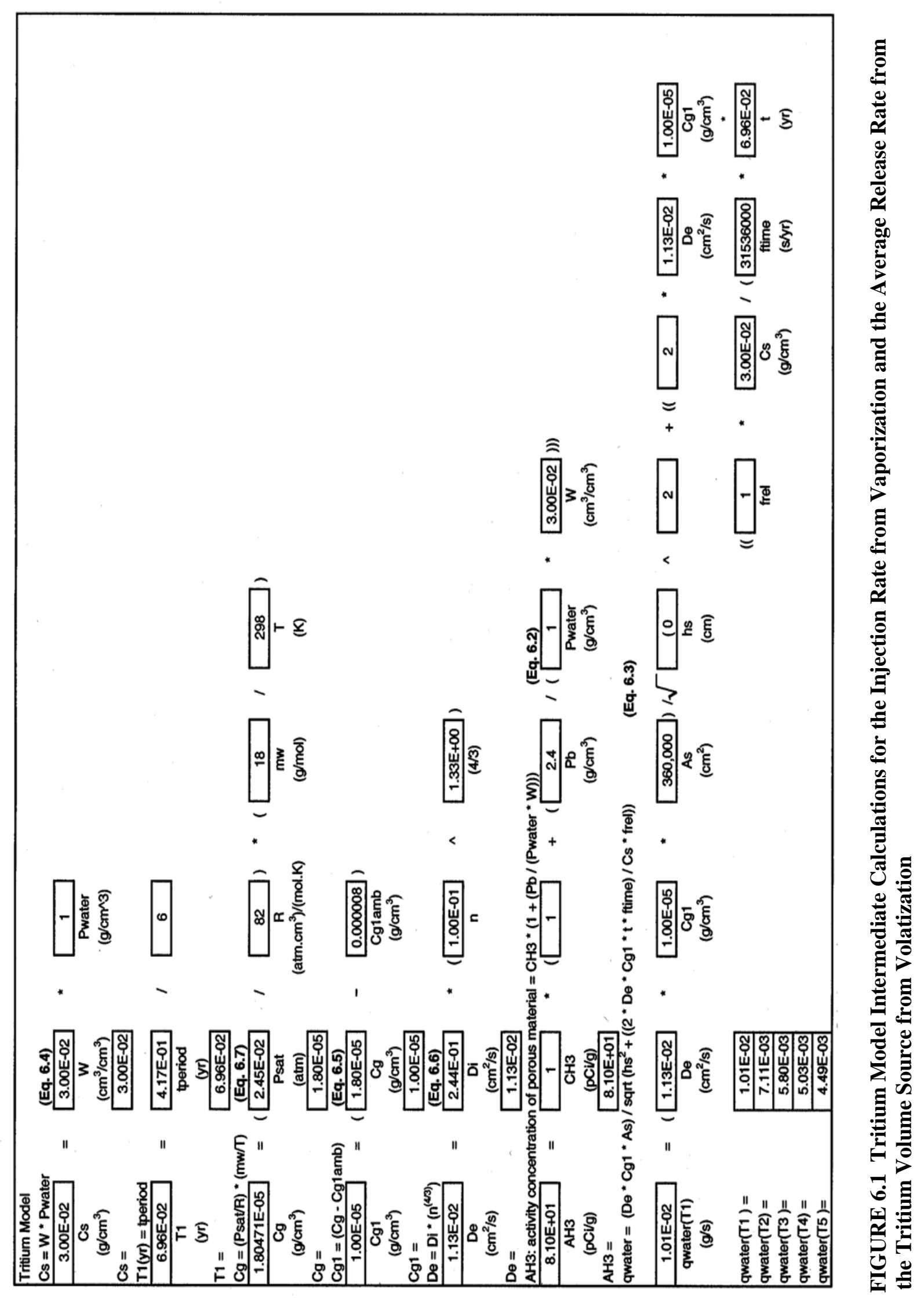




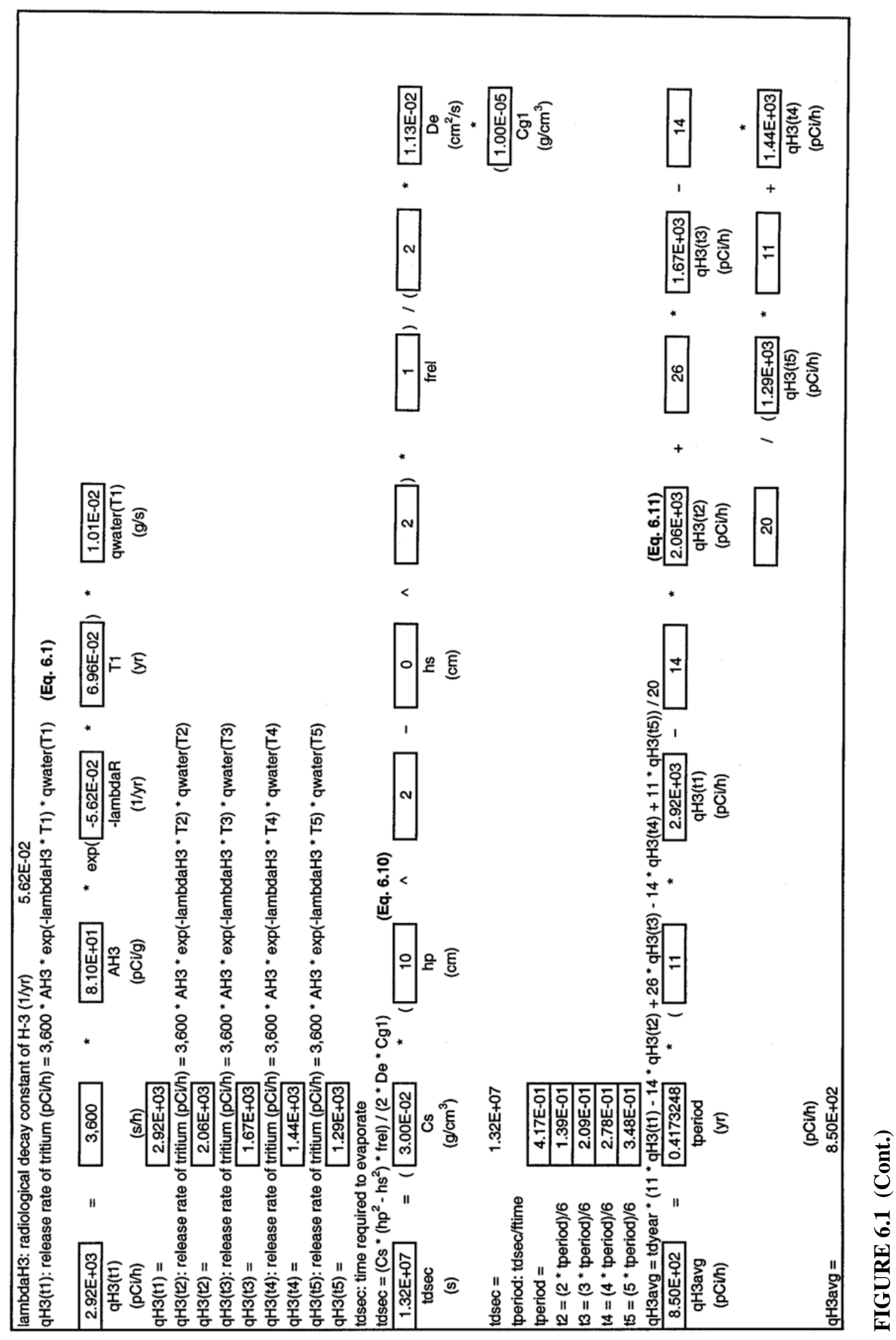




\section{EXTERNAL EXPOSURE MODEL}

In the RESRAD-BUILD code, two direct exposure models based on the geometrical type of sources are used. The first model for area and volume sources is based on a semi-infinite slab source with corrections for geometrical factors. The second model for point and line contamination is a simple dose integral method. The doses from the point and line sources were calculated as described in Sections F.3 and F.4 of the RESRAD-BUILD manual (Yu et al. 1994), respectively.

The external dose for the volume and area sources depends upon the geometry of the source relative to the point where the dose is to be evaluated. In RESRAD-BUILD, the volume source can have up to five layers, and the contamination can be in any of the layers. The source geometry is specified by the source location, source parameters (area, thickness, and density), receptor location, and the shielding thickness between the source and the receptor. The exposure model uses the external DCFs from Federal Guidance Report No. 12 (FGR-12) (Eckerman and Ryman 1993), which include dose contributions from gamma and beta radiation. The methodology described by Kamboj et al. (1998) for corrections due to finite size was extended to include differences due to the source material.

For calculating external exposure from deposited material, only floor deposition was considered and was treated as an area source. The exposure to the receptor was from the deposition in the same room as the receptor only. For example, the receptor in room 1 would be exposed to the deposition in room 1 and would not be exposed to deposition in any other room. Similarly, for the air submersion pathway, the exposure to the receptor was from the radioactive air concentration in the same room as the receptor.

The external pathway dose from exposure to an area or a volume source containing radionuclide $n$ in compartment $I, D_{i v}^{n}$, is expressed as:

$$
D_{i v}^{n}=F_{i n} F_{i} C_{s}^{n} D C F_{v}^{n} F_{G}^{n}
$$

where

$$
\begin{aligned}
\mathrm{F}_{i n} & =\text { fraction of time spent indoors; } \\
F_{i} & =\text { fraction of time spent in compartment } i
\end{aligned}
$$




$$
\begin{aligned}
D C F_{v}{ }^{n}= & \text { FGR-12 dose conversion factor for infinite volume source; and } \\
F_{G}^{n}= & \text { geometrical factor for finite area, source thickness, shielding, source } \\
& \begin{array}{l}
\text { material, and position of receptor relative to the source for } \\
\text { radionuclide } n .
\end{array}
\end{aligned}
$$

The geometrical factor, $F_{G}$, is the ratio of the effective dose equivalent for the actual source to the effective dose equivalent for the standard source. The standard source is a contaminated soil of infinite depth and lateral extent with no cover. The geometrical factor is expressed as the product of the depth-and-cover factor, $F_{C D}$, an area and material factor, $F_{A M}$, and the off-set factor, $F_{O F F-S E T}$.

Dose conversion factors in FGR-12 (Eckerman and Ryman 1993) are given for surface and uniformly distributed volume sources at four specific thicknesses $(1,5$, and $15 \mathrm{~cm}$, and effectively infinite) with a soil density of $1.6 \mathrm{~g} / \mathrm{cm}^{3}$. FGR-12 assumes that sources are infinite in lateral extent. In actual situations, sources can have any depth, shape, cover, and size. A depthand-cover factor function, $F_{C D}$, was developed with regression analysis to express the attenuation for radionuclides. Three independent radionuclide-specific parameters were determined by using the effective dose equivalent values of FGR-12 at different depths. Kamboj et al. (1998) describes how the depth-and-cover function was derived using the effective dose equivalent values of FGR-12 at different depths. A depth-and-cover factor function was derived from the depth factor function by considering both dose contribution and attenuation from different depths:

$$
\frac{D\left(T_{c}=t_{c}, T_{S}=t_{s}\right)}{D\left(T_{c}=0, T_{S}=\infty\right)}=A e^{-K_{A} \rho_{c} t_{c}}\left(1-e^{-K_{A} \rho_{S} t_{S}}\right)+B e^{-K_{B} \rho_{c} t_{c}}\left(1-e^{-K_{B} \rho_{S} t_{s}}\right),
$$

where

$$
\begin{aligned}
A, B= & \text { fit parameters (dimensionless); } \\
K_{A}, K_{B}= & \text { fit parameters }\left(\mathrm{cm}^{2} / \mathrm{g}\right) ; \\
t_{c}= & \text { shielding thickness }(\mathrm{cm}) \text { (the sum of all shielding thicknesses between } \\
& \text { the source and the receptor), the shielding is placed immediately } \\
& \text { adjacent to the source; } \\
\rho_{c}= & \text { shielding density }\left(\mathrm{g} / \mathrm{cm}^{3}\right) \text { (the thickness-averaged density between the } \\
& \text { source and receptor); } \\
t_{s}= & \text { source thickness }(\mathrm{cm}) ;
\end{aligned}
$$




$$
\begin{aligned}
& \rho_{s}=\text { source density }\left(\mathrm{g} / \mathrm{cm}^{3}\right) ; \\
& T_{c}=\text { shielding parameter }(\mathrm{m}) ; \text { and } \\
& T_{s}=\text { source depth parameter }(\mathrm{m}) .
\end{aligned}
$$

The following constraints were put on the four fitting parameters:

1. All the parameters were forced to be positive;

2. $\mathrm{A}+\mathrm{B}=1$; and

3. In the limit source depth, $t_{s} \rightarrow$ zero, the DCF should match the contaminated surface DCF.

All the four unknown parameters $\left(A, B, K_{A}\right.$, and $\left.K_{B}\right)$ were found for 67 radionuclides available in the RESRAD-BUILD computer code. The fitted values of $A, B, K_{A}$, and $K_{B}$ for radionuclides were used in the dose calculations.

For actual geometries (finite area and different materials), the area and material factor, $F_{A M}$, was derived by using the point-kernel method. This factor depends not only on the lateral extent of the contamination but also on source thickness, shielding thickness, gamma energies, and source material through its attenuation and buildup factors. All energies from radionuclide decay were considered separately and weighted by its yield, $y$, energy, $E$, and an energydependent coefficient, $K$, to convert from air-absorbed dose to effective dose equivalent:

$$
F_{A M}=\frac{\sum_{\text {Energies: } j} y_{j} E_{j} K_{j} \int_{V^{\prime}} \frac{B\left(x^{\prime}\right) e^{-\mu x^{\prime}}}{\left(x^{\prime}\right)^{2}} d V}{\sum_{\text {Energies: } j} y_{j} E_{j} K_{j} \int_{V} \frac{B(x) e^{-\mu x}}{(x)^{2}} d V},
$$

where

$$
\begin{gathered}
\left(x^{\prime}\right)^{2}=r^{2}+\left(t_{a}+t_{c}+t\right)^{2}, \\
(x)^{2}=r^{2}+(1 m+t)^{2}
\end{gathered}
$$




$$
\begin{gathered}
\left.\mu=\frac{\left(t_{a} \mu_{a}+t_{c} \mu_{c}+t \mu_{s}\right.}{\left(t_{a}+t_{c}+t\right)}\right), \text { and } \\
B(x)=B_{a}\left(\frac{t_{a}}{t_{a}+t_{c}+t_{s}} x\right) B_{c}\left(\frac{t_{c}}{t_{a}+t_{c}+t_{s}} x\right) B_{s}\left(\frac{t_{s}}{t_{a}+t_{c}+t_{s}} x\right) .
\end{gathered}
$$

$B$ and $\mu$ are the buildup factor and the attenuation factor, respectively, for the appropriate material ( $a$ for air, $c$ for shield material, and $s$ for source material or soil reference). The integration volume $V^{\prime}$ is the desired geometry of specified material with radius $R$, shielding thickness $t_{c}$, and air thickness $t_{a}$; whereas $V$ is the reference geometry of soil extending infinitely laterally with no shield and the receptor midpoint located $1 \mathrm{~m}$ from the surface.

The off-set factor, $F_{O F F-S E T}$, is the ratio of the dose estimates from a noncircular shaped contaminated material to a reference shape. The concept of the shape factor is used to calculate the off-set factor. The reference shape is a fully contaminated circular area encompassing the given shape, centered about the receptor. This factor is derived by considering the area, material factors of a series of concentric circles, and the corresponding contamination fraction of the annular regions. The off-set factor is obtained by enclosing the irregularly shaped contaminated area in a circle, multiplying the area factor of each annulus by the fraction of the contaminated annulus area, $f_{i}$, summing the products, and dividing by the area factor of a circular contaminated material that is equivalent in area:

$$
F_{\text {OFF }-S E T}=\frac{\sum_{i=0}^{n} f_{i}\left[F_{A}\left(A_{i}\right)-F_{A}\left(A_{i-1}\right)\right]}{F_{A}\left[\sum_{i=0}^{n} f_{i}\left(A_{i}-A_{i-1}\right)\right]} .
$$

Because RESRAD-BUILD does not give intermediate results (i.e., geometrical, depthand-cover, area and material, and off-set factors) for the external exposure pathway, only the pathway doses were compared with the spreadsheet results in Section 8.6. The results of the external exposure models (point and line sources and area and volume sources) were also benchmarked with those from the MCNP transport code. For this comparison, MCNP version 4A was used.

The point source dose was compared at three receptor distances $(15,100$, and 1,000 cm) for three radionuclides: Co-60 (1.25 MeV, gamma abundance 200\%), Mn-54 (836 keV, gamma abundance $100 \%)$, and $\mathrm{Au}-195$ (71.6 keV, gamma abundance 110\%) to cover different energy sources. Table 7.1 presents the comparison of the RESRAD-BUILD calculated results with the MCNP calculations. All results are within 5\% of each other. 
TABLE 7.1 Point Source Dose ([mrem/yr]/pCi) Comparison between RESRAD-BUILD ${ }^{a}$ and MCNP

\begin{tabular}{|c|c|c|c|c|c|c|}
\hline \multirow[b]{3}{*}{ Radionuclide } & \multicolumn{6}{|c|}{ Receptor Distances $(\mathrm{cm})$} \\
\hline & \multicolumn{2}{|c|}{15} & \multicolumn{2}{|c|}{100} & \multicolumn{2}{|c|}{1,000} \\
\hline & $\begin{array}{l}\text { RESRAD- } \\
\text { BUILD }\end{array}$ & MCNP & $\begin{array}{l}\text { RESRAD- } \\
\text { BUILD }\end{array}$ & MCNP & $\begin{array}{l}\text { RESRAD- } \\
\text { BUILD }\end{array}$ & MCNP \\
\hline $\mathrm{Au}-195$ & $1.24 \mathrm{E}-05$ & $1.24 \mathrm{E}-05$ & $2.86 \mathrm{E}-07$ & $2.84 \mathrm{E}-07$ & 3.57E-09 & 3.33E-09 \\
\hline Mn-54 & $1.31 \mathrm{E}-04$ & $1.32 \mathrm{E}-04$ & $2.95 \mathrm{E}-06$ & $2.96 \mathrm{E}-06$ & $2.91 \mathrm{E}-08$ & $2.91 \mathrm{E}-08$ \\
\hline Co-60 & $3.72 \mathrm{E}-04$ & $3.72 \mathrm{E}-04$ & $8.36 \mathrm{E}-06$ & $8.35 \mathrm{E}-06$ & $8.25 \mathrm{E}-08$ & $8.17 \mathrm{E}-08$ \\
\hline
\end{tabular}

a Point source external exposure pathway dose from test case 10.

The line source dose was compared at three receptor distances $(10,100$, and 1,000 cm) for the same three radionuclides as was used for the point source comparison. The comparison was performed for line sources of four different lengths $(1,10,100$, and 1,000 cm). Table 7.2 presents the comparison of the RESRAD-BUILD calculated results with the MCNP calculations. All results are within $1 \%$ of each other.

The area source dose was compared at three receptor distances $(15,100$, and 1,000 cm) for the same three radionuclides as were used for the point source comparison. The comparison was performed for a source area of $3.2 \mathrm{~m}^{2}$. Table 7.3 presents the comparison of the RESRADBUILD calculated results with the MCNP calculations. All results are within $5 \%$ of each other.

The volume source dose was compared at three receptor distances $(15,100$, and 1,000 cm) for Au-195, Mn-54, and Co-60. The comparison was performed for a source density of $2.4 \mathrm{~g} / \mathrm{cm}^{3}$, an area of $3.2 \mathrm{~m}^{2}$, and three thicknesses $(1,10$, and $50 \mathrm{~cm})$. Table 7.4 presents the comparison of the RESRAD-BUILD calculated results with the MCNP calculations with agreement within $20 \%$. The comparison includes the area and material factor, off-set factor, and depth-and-cover factor.

The external exposure model was also compared with MCNP calculations for RESRADBUILD default parameter values for point, line, surface, and volume sources. The radionuclides used in this comparison were the same as before (Au-195, Mn-54, and Co-60) to cover a wide energy range. Table 7.5 presents the comparison of the values from RESRAD-BUILD code output and MCNP code calculations. The results of the RESRAD-BUILD code for case 10a are provided in the Appendix. The results match within 1\% for point sources, within 5\% for line and area sources, and within $10 \%$ for volume source for all radionuclides. For higher energy radionuclides, Mn-54 and Co-60, the results agree within 3\%. 
TABLE 7.2 Line Source Dose ([mrem/yr]/[pCi/m]) Comparison between RESRAD-BUILD ${ }^{\mathrm{a}}$ and MCNP

\begin{tabular}{|c|c|c|c|c|c|c|}
\hline \multirow[b]{3}{*}{ Radionuclide } & \multicolumn{6}{|c|}{ Receptor Distances $(\mathrm{cm})$} \\
\hline & \multicolumn{2}{|c|}{10} & \multicolumn{2}{|c|}{100} & \multicolumn{2}{|c|}{1,000} \\
\hline & $\begin{array}{l}\text { RESRAD- } \\
\text { BUILD }\end{array}$ & MCNP & $\begin{array}{c}\text { RESRAD- } \\
\text { BUILD }\end{array}$ & MCNP & $\begin{array}{c}\text { RESRAD- } \\
\text { BUILD }\end{array}$ & MCNP \\
\hline \multicolumn{7}{|c|}{ Line source length $=1 \mathrm{~cm}$} \\
\hline $\mathrm{Au}-195$ & 2.79E-07 & $2.77 \mathrm{E}-07$ & $2.86 \mathrm{E}-09$ & $2.84 \mathrm{E}-09$ & $3.57 \mathrm{E}-11$ & $3.33 \mathrm{E}-11$ \\
\hline Mn-54 & $2.95 \mathrm{E}-06$ & $2.96 \mathrm{E}-06$ & $2.95 \mathrm{E}-08$ & $3.02 \mathrm{E}-08$ & $2.91 \mathrm{E}-10$ & $2.91 \mathrm{E}-10$ \\
\hline Co-60 & $8.37 \mathrm{E}-06$ & $8.36 \mathrm{E}-06$ & $8.36 \mathrm{E}-08$ & 8.34E-08 & $8.25 \mathrm{E}-10$ & $8.18 \mathrm{E}-10$ \\
\hline \multicolumn{7}{|c|}{ Line source length $=10 \mathrm{~cm}$} \\
\hline Au-195 & $2.59 \mathrm{E}-06$ & $2.57 \mathrm{E}-06$ & $2.85 \mathrm{E}-08$ & $2.84 \mathrm{E}-08$ & $3.57 \mathrm{E}-10$ & $3.33 \mathrm{E}-10$ \\
\hline Mn-54 & $2.74 \mathrm{E}-05$ & $2.75 \mathrm{E}-05$ & $2.95 \mathrm{E}-07$ & $2.96 \mathrm{E}-07$ & $2.91 \mathrm{E}-09$ & $2.91 \mathrm{E}-09$ \\
\hline Co-60 & 7.77E-05 & $7.76 \mathrm{E}-05$ & $8.35 \mathrm{E}-07$ & $8.34 \mathrm{E}-07$ & $8.25 \mathrm{E}-09$ & $8.18 \mathrm{E}-09$ \\
\hline \multicolumn{7}{|c|}{ Line source length $=100 \mathrm{~cm}$} \\
\hline $\mathrm{Au}-195$ & $7.67 \mathrm{E}-06$ & 7.63E-06 & $2.65 \mathrm{E}-07$ & $2.64 \mathrm{E}-07$ & $3.57 \mathrm{E}-09$ & 3.32E-09 \\
\hline Mn-54 & $8.11 \mathrm{E}-05$ & $8.11 \mathrm{E}-05$ & $2.73 \mathrm{E}-06$ & $2.74 \mathrm{E}-06$ & $2.91 \mathrm{E}-08$ & $2.90 \mathrm{E}-08$ \\
\hline Co-60 & $2.30 \mathrm{E}-04$ & 2.29E-04 & $7.75 \mathrm{E}-06$ & 7.74E-06 & 8.22E-08 & $8.18 \mathrm{E}-08$ \\
\hline \multicolumn{7}{|c|}{ Line source length $=1,000 \mathrm{~cm}$} \\
\hline $\mathrm{Au}-195$ & 8.64E-06 & 8.63E-06 & 7.73E-07 & $7.89 \mathrm{E}-06$ & $3.28 \mathrm{E}-08$ & $3.13 \mathrm{E}-08$ \\
\hline Mn-54 & $9.15 \mathrm{E}-05$ & $9.16 \mathrm{E}-05$ & $8.05 \mathrm{E}-06$ & $8.12 \mathrm{E}-06$ & $2.69 \mathrm{E}-07$ & $2.70 \mathrm{E}-07$ \\
\hline Co-60 & $2.59 \mathrm{E}-04$ & $2.58 \mathrm{E}-04$ & $2.29 \mathrm{E}-05$ & $2.28 \mathrm{E}-05$ & 7.63E-07 & $7.60 \mathrm{E}-07$ \\
\hline \multirow{2}{*}{\multicolumn{7}{|c|}{$\begin{array}{l}{ }^{a} \text { Line source external exposure pathway dose from test case } 13 \text {. } \\
\text { TABLE 7.3 Area Source Dose }\left([\mathrm{mrem} / \mathbf{y r}] /\left[\mathbf{p C i} / \mathbf{m}^{2}\right]\right) \text { Comparison between } \\
\text { RESRAD-BUILDa and MCNP }\end{array}$}} \\
\hline & & & & & & \\
\hline & \multicolumn{6}{|c|}{ Receptor Distances (cm) } \\
\hline & \multicolumn{2}{|c|}{15} & \multicolumn{2}{|c|}{100} & \multicolumn{2}{|c|}{1,000} \\
\hline Radionuclide & $\begin{array}{l}\text { RESRAD- } \\
\text { BUILD }\end{array}$ & MCNP & $\begin{array}{l}\text { RESRAD- } \\
\text { BUILD }\end{array}$ & MCNP & $\begin{array}{l}\text { RESRAD- } \\
\text { BUILD }\end{array}$ & MCNP \\
\hline $\mathrm{Au}-195$ & $3.16 \mathrm{E}-06$ & $3.37 \mathrm{E}-06$ & $5.88 \mathrm{E}-07$ & $6.18 \mathrm{E}-07$ & $1.06 \mathrm{E}-08$ & $1.04 \mathrm{E}-08$ \\
\hline $\mathrm{Mn}-54$ & $3.41 \mathrm{E}-05$ & $3.57 \mathrm{E}-05$ & $6.23 \mathrm{E}-06$ & $6.46 \mathrm{E}-06$ & 8.89E-08 & $9.20 \mathrm{E}-08$ \\
\hline Co-60 & $9.70 \mathrm{E}-05$ & $1.01 \mathrm{E}-04$ & $1.78 \mathrm{E}-05$ & $1.82 \mathrm{E}-05$ & $2.53 \mathrm{E}-07$ & $2.56 \mathrm{E}-07$ \\
\hline
\end{tabular}

a Area source external exposure pathway dose from test case 11. 
TABLE 7.4 Volume Source Dose ([mrem/yr $] /[\mathrm{pCi} / \mathrm{m}])$ Comparison between RESRAD-BUILDa and MCNP

\begin{tabular}{|c|c|c|c|c|c|c|}
\hline \multirow[b]{3}{*}{ Radionuclide } & \multicolumn{6}{|c|}{ Receptor Distances $(\mathrm{cm})$} \\
\hline & \multicolumn{2}{|c|}{15} & \multicolumn{2}{|c|}{100} & \multicolumn{2}{|c|}{1,000} \\
\hline & $\begin{array}{l}\text { RESRAD- } \\
\text { BUILD }\end{array}$ & MCNP & $\begin{array}{l}\text { RESRAD- } \\
\text { BUILD }\end{array}$ & MCNP & $\begin{array}{c}\text { RESRAD- } \\
\text { BUILD }\end{array}$ & MCNP \\
\hline \multicolumn{7}{|c|}{ Source thickness $=1 \mathrm{~cm}$} \\
\hline $\mathrm{Au}-195$ & 0.0688 & 0.0684 & 0.0146 & 0.0176 & $2.15 \mathrm{E}-04$ & $2.85 \mathrm{E}-04$ \\
\hline Mn-54 & 0.758 & 0.848 & 0.143 & 0.173 & 0.00206 & 0.00249 \\
\hline Co-60 & 2.12 & 2.38 & 0.402 & 0.472 & 0.00579 & 0.00673 \\
\hline \multicolumn{7}{|c|}{ Source thickness $=10 \mathrm{~cm}$} \\
\hline $\mathrm{Au}-195$ & 0.135 & 0.142 & 0.0463 & 0.0506 & 7.39E-04 & 8.94E-04 \\
\hline Mn-54 & 3.80 & 3.57 & 1.03 & 1.10 & 0.0161 & 0.0179 \\
\hline Co-60 & 11.4 & 10.9 & 3.01 & 3.20 & 0.0469 & 0.0510 \\
\hline \multicolumn{7}{|c|}{ Source thickness $=50 \mathrm{~cm}$} \\
\hline $\mathrm{Au}-195$ & 0.133 & 0.146 & 0.0459 & 0.0516 & $7.35 \mathrm{E}-04$ & $9.15 \mathrm{E}-04$ \\
\hline Mn-54 & 4.12 & 4.28 & 1.34 & 1.45 & 0.0236 & 0.0254 \\
\hline Co-60 & 12.7 & 13.6 & 4.07 & 4.53 & 0.0727 & 0.0803 \\
\hline
\end{tabular}

a Volume source external exposure pathway dose from test case 12.

TABLE 7.5 Direct External Exposure Pathway Dose (mrem/yr) Comparison between RESRAD-BUILD ${ }^{a}$ and MCNP Using Default Parameters

\begin{tabular}{|c|c|c|c|c|c|c|c|c|}
\hline \multirow[b]{2}{*}{ Radionuclide } & \multicolumn{2}{|c|}{ Point } & \multicolumn{2}{|c|}{ Line } & \multicolumn{2}{|c|}{ Area } & \multicolumn{2}{|c|}{ Volume } \\
\hline & $\begin{array}{c}\text { RESRAD- } \\
\text { BUILD }\end{array}$ & MCNP & $\begin{array}{l}\text { RESRAD- } \\
\text { BUILD }\end{array}$ & MCNP & $\begin{array}{l}\text { RESRAD- } \\
\text { BUILD }\end{array}$ & MCNP & $\begin{array}{l}\text { RESRAD- } \\
\text { BUILD }\end{array}$ & MCNP \\
\hline Au-195 & $4.85 \mathrm{E}-08$ & $4.80 \mathrm{E}-08$ & 2.94E-07 & $3.10 \mathrm{E}-07$ & $1.01 \mathrm{E}-06$ & $1.08 \mathrm{E}-06$ & 0.0534 & 0.0596 \\
\hline Mn-54 & 4.91E-07 & $4.93 \mathrm{E}-07$ & 3.07E-06 & $3.10 \mathrm{E}-06$ & $1.05 \mathrm{E}-05$ & $1.10 \mathrm{E}-05$ & 1.64 & 1.60 \\
\hline Co-60 & $1.39 \mathrm{E}-06$ & $1.39 \mathrm{E}-06$ & 8.72E-06 & 8.74E-06 & $3.00 \mathrm{E}-05$ & $3.10 \mathrm{E}-05$ & 4.98 & 4.89 \\
\hline
\end{tabular}

a External exposure pathway dose from test case 10a. 


\section{DIFFERENT PATHWAY DOSES}

This section discusses the comparison of the different pathway doses calculated by the RESRAD-BUILD code with the spreadsheet calculations. Individual pathway doses for a single radionuclide were compared first, followed by a comparison of the total receptor dose. The RESRAD-BUILD code generated output files — diag.out and resradb.rpt — for all 17 cases are provided in the Appendix. Table 2.3 lists all the relevant files used in each verification calculation.

\subsection{SUBMERSION PATHWAY}

The air submersion external dose from exposure to indoor contaminated air was calculated by using the following equation (Yu et al. 1994, Equation F.13):

$$
D_{i, s u b}^{n}(t)=F_{\text {in }} F_{i} C_{i}^{n}(t) D C F_{\text {sub }}^{n},
$$

where

$$
\begin{aligned}
D_{i, \text { sub }}^{n}(t)= & \text { total annual air submersion effective dose equivalent from } \\
& \text { radionuclide } n \text { at time } \mathrm{t} \text { in compartment } i(\mathrm{mrem} / \mathrm{yr}) ; \\
C_{i}^{n}(t)= & \text { average concentration of radionuclide } n \text { at time } t \text { in the indoor air } \\
& \text { of compartment } i\left(\mathrm{pCi} / \mathrm{m}^{3}\right) ; \text { and }
\end{aligned}
$$

Figure 8.1 shows the spreadsheet calculations for the default parameter set. The air concentration, C1N, in Figure 8.1 is from the calculated air concentration in Figure 4.1 for the volume source. Table 8.1 provides the RESRAD-BUILD and spreadsheet calculated values of the submersion pathway doses for the three sets of parameters for the one-room model. The doses were compared for volume, area, line, and point sources. The comparison was performed for Na-22 and Al-26 at time zero, with excellent agreement between the code output and spreadsheet verification. 


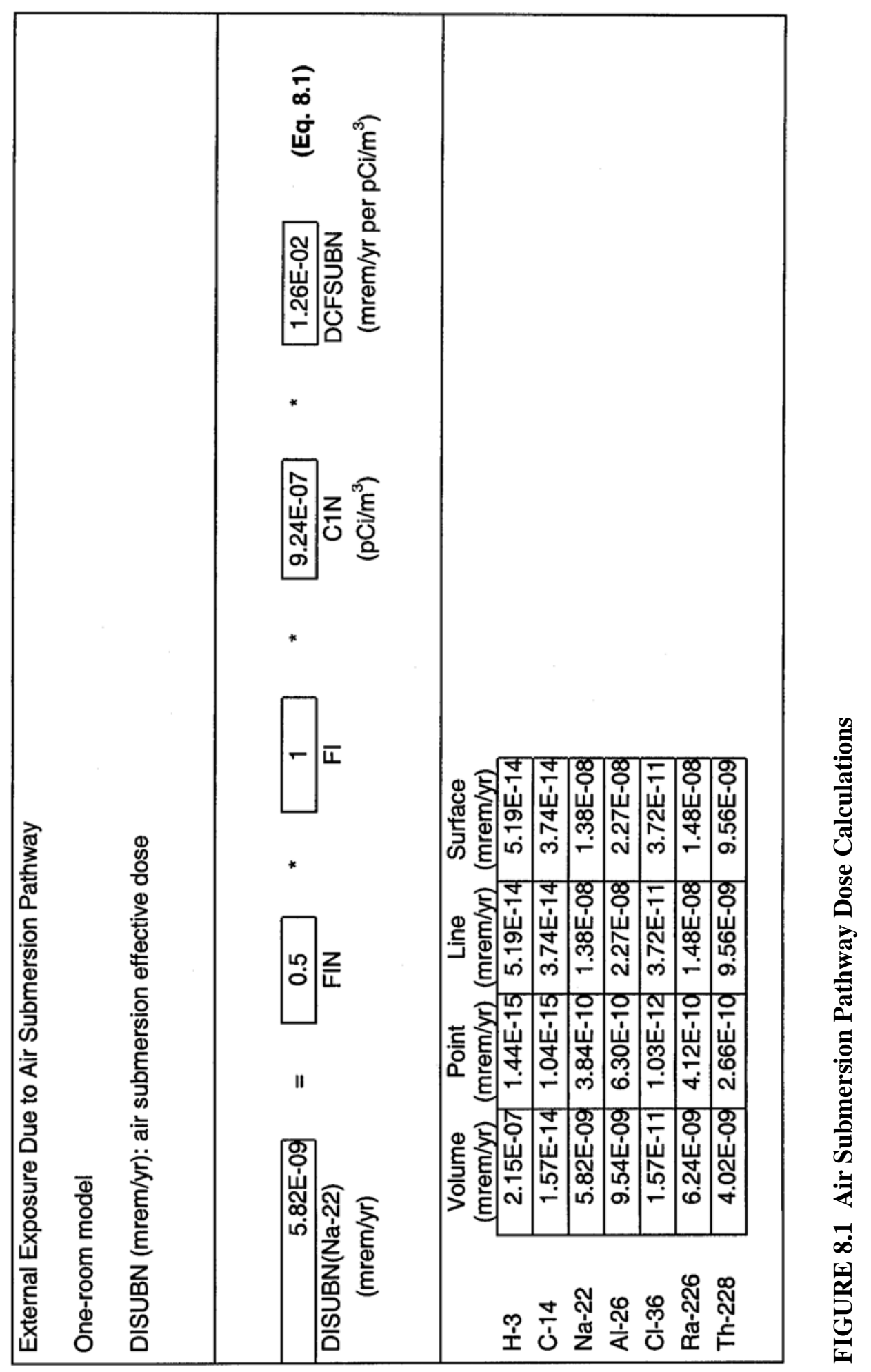


TABLE 8.1 RESRAD-BUILD and Spreadsheet Submersion Pathway Dose (mrem/yr) Values for Three Sets of Input Parameters

\begin{tabular}{|c|c|c|c|c|c|c|}
\hline \multirow[b]{2}{*}{$\begin{array}{l}\text { Source } \\
\text { Type }\end{array}$} & \multicolumn{2}{|c|}{ Default $^{\mathrm{a}}$} & \multicolumn{2}{|c|}{ Lower $^{b}$} & \multicolumn{2}{|c|}{ Upperc $^{\mathrm{c}}$} \\
\hline & $\begin{array}{l}\text { RESRAD- } \\
\text { BUILD }\end{array}$ & Spreadsheet & $\begin{array}{c}\text { RESRAD- } \\
\text { BUILD }\end{array}$ & Spreadsheet & $\begin{array}{l}\text { RESRAD- } \\
\text { BUILD }\end{array}$ & Spreadsheet \\
\hline \multicolumn{7}{|l|}{$\mathrm{Na}-22$} \\
\hline Volume & 5.83E-09 & $5.82 \mathrm{E}-09$ & $1.72 \mathrm{E}-11$ & $1.72 \mathrm{E}-11$ & $8.97 \mathrm{E}-06$ & $8.96 \mathrm{E}-06$ \\
\hline Area & $1.39 \mathrm{E}-08$ & $1.38 \mathrm{E}-08$ & $9.82 \mathrm{E}-11$ & $9.81 \mathrm{E}-11$ & $1.28 \mathrm{E}-09$ & $1.28 \mathrm{E}-09$ \\
\hline Line & $1.39 \mathrm{E}-08$ & $1.38 \mathrm{E}-08$ & $9.82 \mathrm{E}-11$ & $9.81 \mathrm{E}-11$ & $1.28 \mathrm{E}-09$ & $1.28 \mathrm{E}-09$ \\
\hline Point & $3.85 \mathrm{E}-10$ & $3.84 \mathrm{E}-10$ & $2.73 \mathrm{E}-11$ & $2.72 \mathrm{E}-11$ & $3.56 \mathrm{E}-12$ & $3.55 \mathrm{E}-12$ \\
\hline \multicolumn{7}{|l|}{ Al-26 } \\
\hline Volume & $9.55 \mathrm{E}-09$ & $9.54 \mathrm{E}-09$ & $2.17 \mathrm{E}-11$ & $2.17 \mathrm{E}-11$ & $1.13 \mathrm{E}-05$ & $1.13 \mathrm{E}-05$ \\
\hline Area & $2.27 \mathrm{E}-08$ & 2.27E-08 & $1.24 \mathrm{E}-10$ & $1.24 \mathrm{E}-10$ & $1.62 \mathrm{E}-09$ & 1.61E-09 \\
\hline Line & 2.27E-08 & 2.27E-08 & $1.24 \mathrm{E}-10$ & $1.24 \mathrm{E}-10$ & $1.62 \mathrm{E}-09$ & $1.61 \mathrm{E}-09$ \\
\hline Point & $6.31 \mathrm{E}-10$ & $6.30 \mathrm{E}-10$ & $3.44 \mathrm{E}-11$ & $3.44 \mathrm{E}-11$ & $4.49 \mathrm{E}-12$ & $4.48 \mathrm{E}-12$ \\
\hline
\end{tabular}

\subsection{INADVERTENT INGESTION DIRECTLY FROM THE SOURCE}

The component of the effective dose equivalent due to ingestion of loose material directly from the volume source in compartment $i$ containing radionuclide $n$ was calculated by using the following equation (Yu et al. 1994, Equation E.1):

$$
D_{i l}^{n}(t)=\left(8,760 F_{i n} F_{i}\right) E R C_{s}^{n}(t) D C F_{g}^{n}
$$

where

$$
\begin{aligned}
D_{i l}^{n}(t)= & \text { annual component of the total effective dose equivalent due to } \\
& \text { ingestion of loose material directly from the source containing } \\
& \text { radionuclide } n \text { at time } t \text { in compartment } i(\mathrm{mrem} / \mathrm{yr}) ; \\
8,760= & \text { time conversion factor (number of hours per year) }(\mathrm{h} / \mathrm{yr}) ; \\
F_{\text {in }}= & \text { fraction of time spent indoors (dimensionless); }
\end{aligned}
$$




$$
\begin{aligned}
F_{i}= & \text { fraction of indoor time spent at compartment } i \text { (dimensionless); } \\
E R= & \text { ingestion rate of loose material directly from the source }(\mathrm{g} / \mathrm{h}) ; \\
C_{s}^{n}(t)= & \begin{array}{l}
\text { average concentration of radionuclide } n \text { in the source material } \\
\\
(\mathrm{pCi} / \mathrm{g}) \text { at time } t ; \text { and }
\end{array} \\
D C F_{g}^{n}= & \text { ingestion } \mathrm{DCF} \text { related to radionuclide } n(\mathrm{mrem} / \mathrm{pCi}) .
\end{aligned}
$$

Surface, line, and point sources, for compartment $i$ can be calculated with the following equation (Yu et al. 1994, Equation E.2):

$$
D_{i l}^{n}(t)=\left(8,760 F_{\text {in }} F_{i}\right) E R_{l} f_{R} Q_{s}^{n}(t) D C F_{g}^{n},
$$

where

$f_{R}=$ removable fraction of the source material;

$E R_{l}=$ ingestion rate of loose material directly from the source as a fraction of the source per unit time $(1 / \mathrm{h})$; and

$Q_{s}^{n}(t)=$ average total radionuclide activity in the source (pCi) at time $t$.

Figure 8.2 shows the spreadsheet calculations for the upper bound parameter set. Table 8.2 provides the RESRAD-BUILD and spreadsheet calculated values of the inadvertent ingestion pathway doses for the three sets of parameters for the one-room model. The doses were compared for volume, area, line, and point sources. The comparison was performed for Na-22 and $\mathrm{Al}-26$ at time zero; again, excellent agreement was obtained between the code output and the spreadsheet results. The direct inadvertent ingestion pathway dose for lower bound and default parameters is zero because of the zero direct ingestion rate. 


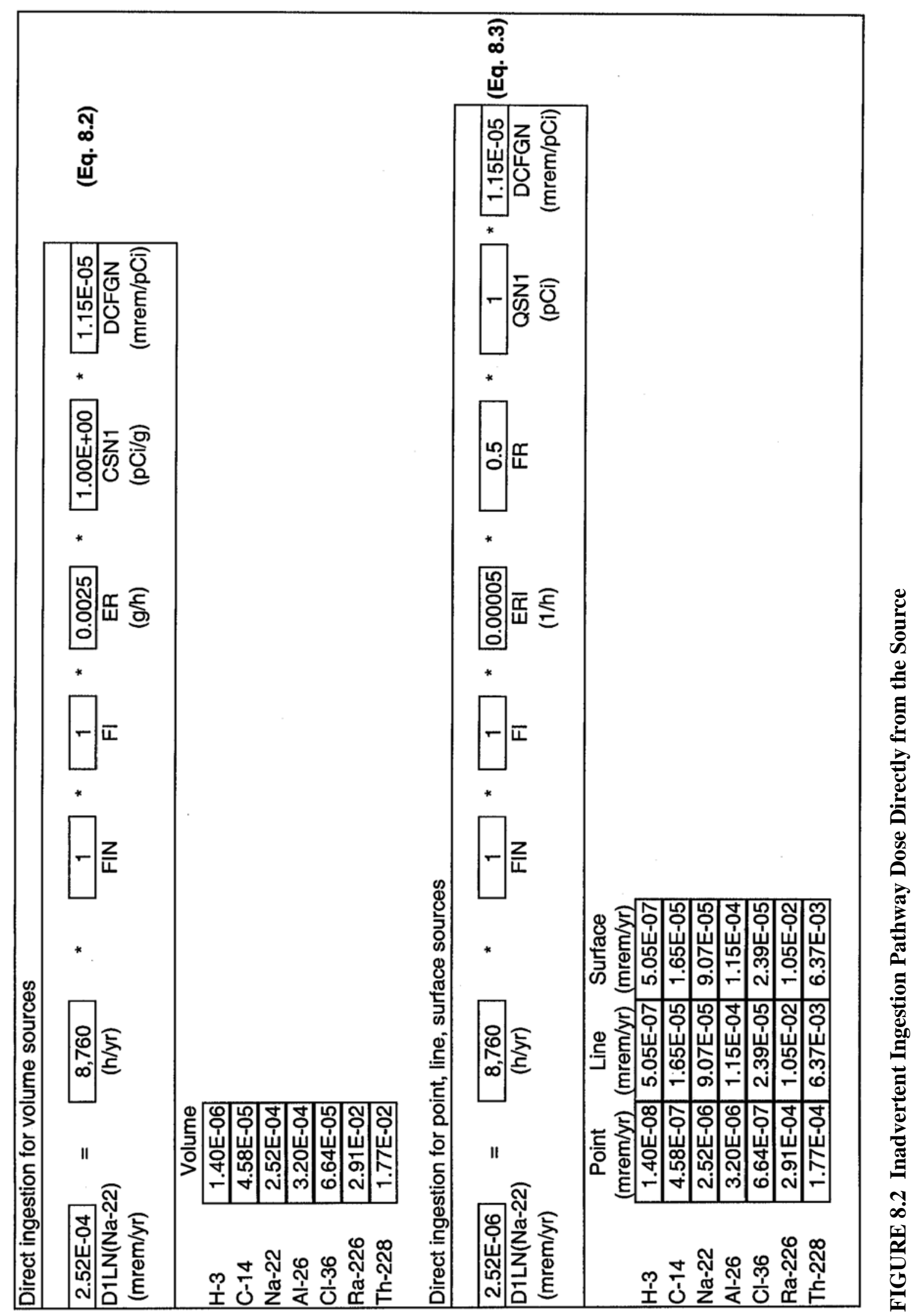


TABLE 8.2 RESRAD-BUILD and Spreadsheet Direct Inadvertent Ingestion Pathway Dose $(\mathrm{mrem} / \mathrm{yr})$ Values for Three Sets of Input Parameters

\begin{tabular}{|c|c|c|c|c|c|c|}
\hline \multirow[b]{2}{*}{$\begin{array}{c}\text { Source } \\
\text { Type }\end{array}$} & \multicolumn{2}{|c|}{ Default ${ }^{\mathrm{a}}$} & \multicolumn{2}{|c|}{ Lower $^{b}$} & \multicolumn{2}{|c|}{ Upper $^{\mathrm{c}}$} \\
\hline & $\begin{array}{l}\text { RESRAD- } \\
\text { BUILD }\end{array}$ & Spreadsheet & $\begin{array}{l}\text { RESRAD- } \\
\text { BUILD }\end{array}$ & Spreadsheet & $\begin{array}{l}\text { RESRAD- } \\
\text { BUILD }\end{array}$ & Spreadsheet \\
\hline \multicolumn{7}{|l|}{$\mathrm{Na}-22$} \\
\hline Volume & 0.0 & 0.0 & 0.0 & 0.0 & $2.52 \mathrm{E}-04$ & $2.52 \mathrm{E}-04$ \\
\hline Area & 0.0 & 0.0 & 0.0 & 0.0 & $9.07 \mathrm{E}-04$ & $9.07 \mathrm{E}-04$ \\
\hline Line & 0.0 & 0.0 & 0.0 & 0.0 & $9.07 \mathrm{E}-04$ & $9.07 \mathrm{E}-04$ \\
\hline Point & 0.0 & 0.0 & 0.0 & 0.0 & $2.52 \mathrm{E}-06$ & $2.52 \mathrm{E}-06$ \\
\hline \multicolumn{7}{|l|}{ Al-26 } \\
\hline Volume & 0.0 & 0.0 & 0.0 & 0.0 & $3.20 \mathrm{E}-04$ & $3.20 \mathrm{E}-04$ \\
\hline Area & 0.0 & 0.0 & 0.0 & 0.0 & $1.15 \mathrm{E}-03$ & $1.15 \mathrm{E}-03$ \\
\hline Line & 0.0 & 0.0 & 0.0 & 0.0 & $1.15 \mathrm{E}-03$ & $1.15 \mathrm{E}-03$ \\
\hline Point & 0.0 & 0.0 & 0.0 & 0.0 & $3.20 \mathrm{E}-06$ & $3.20 \mathrm{E}-06$ \\
\hline
\end{tabular}

a Direct inadvertent ingestion pathway dose from test case 1-DI.

b Direct inadvertent ingestion pathway dose from test case 2-DI.

c Direct inadvertent ingestion pathway dose from test case 3-DI.

\subsection{INADVERTENT INGESTION OF DEPOSITED MATERIALS}

The component of the effective dose equivalent due to ingestion of radioactive dust particulates deposited onto surfaces was calculated by using the following equation:

$$
D_{i d}^{n}(t)=\left(8,760 F_{i n} F_{i}\right) \operatorname{SER} C_{d i}^{n}(t) D C F_{g}^{n},
$$

where

$$
\begin{aligned}
D_{i d}^{n}(t)= & \text { annual component of the total effective dose equivalent, due to } \\
& \begin{array}{l}
\text { ingestion of deposited dust particulates containing radionuclide } n \text { in } \\
\\
\text { compartment } i \text { at time } t(\mathrm{mrem} / \mathrm{yr}) ;
\end{array} \\
8,760= & \text { time conversion factor (number of hours per year) }(\mathrm{h} / \mathrm{yr}) ; \\
F_{\text {in }}= & \text { fraction of time spent indoors (dimensionless); }
\end{aligned}
$$


$F_{i}=$ fraction of indoor time spent at compartment $i$ (dimensionless);

$S E R=$ surface ingestion rate or the ingestion rate of dust particulates deposited onto horizontal surfaces $\left(\mathrm{m}^{2} / \mathrm{h}\right)$;

$C_{d i}^{n}(t)=$ average surface concentration of radionuclide $n$, deposited onto horizontal surfaces of compartment $i\left(\mathrm{pCi} / \mathrm{m}^{2}\right)$ at time $t$; and

$D C F_{g}^{n}=$ ingestion DCF for radionuclide $n(\mathrm{mrem} / \mathrm{pCi})$.

Figure 8.3 shows the spreadsheet calculations for the default parameter set. The surface concentration from deposition, CDIN, in Figure 8.3 is from the calculated surface concentration in Figure 4.5 for the volume and point sources. Table 8.3 provides the RESRAD-BUILD and spreadsheet calculated values of the inadvertent ingestion of deposited material pathway doses for the three sets of parameters for the one-room model. The doses were compared for volume, area, line, and point sources. The comparison was performed for Na-22 and Al-26 at time zero. The spreadsheet verification results matched the code output.

\subsection{DOSE FROM INHALATION OF AIRBORNE RADIOACTIVE PARTICULATES}

The committed effective dose equivalent due to inhalation of radionuclides in the indoor air of compartment $i$ was calculated by using the following equation (Yu et al. 1994, Equation D.3):

$$
D_{i h}^{n}(t)=\left(365 F_{i n} F_{i}\right) I R C_{i}^{n}(t) D C F_{h}^{n},
$$

where

$$
\begin{aligned}
D_{i h}^{n}(t)= & \begin{array}{c}
\text { annual total effective dose equivalent due to inhalation of } \\
\text { radionuclide } n \text { at time } t \text { in compartment } i(\mathrm{mrem} / \mathrm{yr}) ;
\end{array} \\
365 & =\text { time conversion factor (number of days per year) }(\mathrm{d} / \mathrm{yr}) ; \\
F_{i n} & =\text { fraction of time spent indoors (dimensionless); }
\end{aligned}
$$




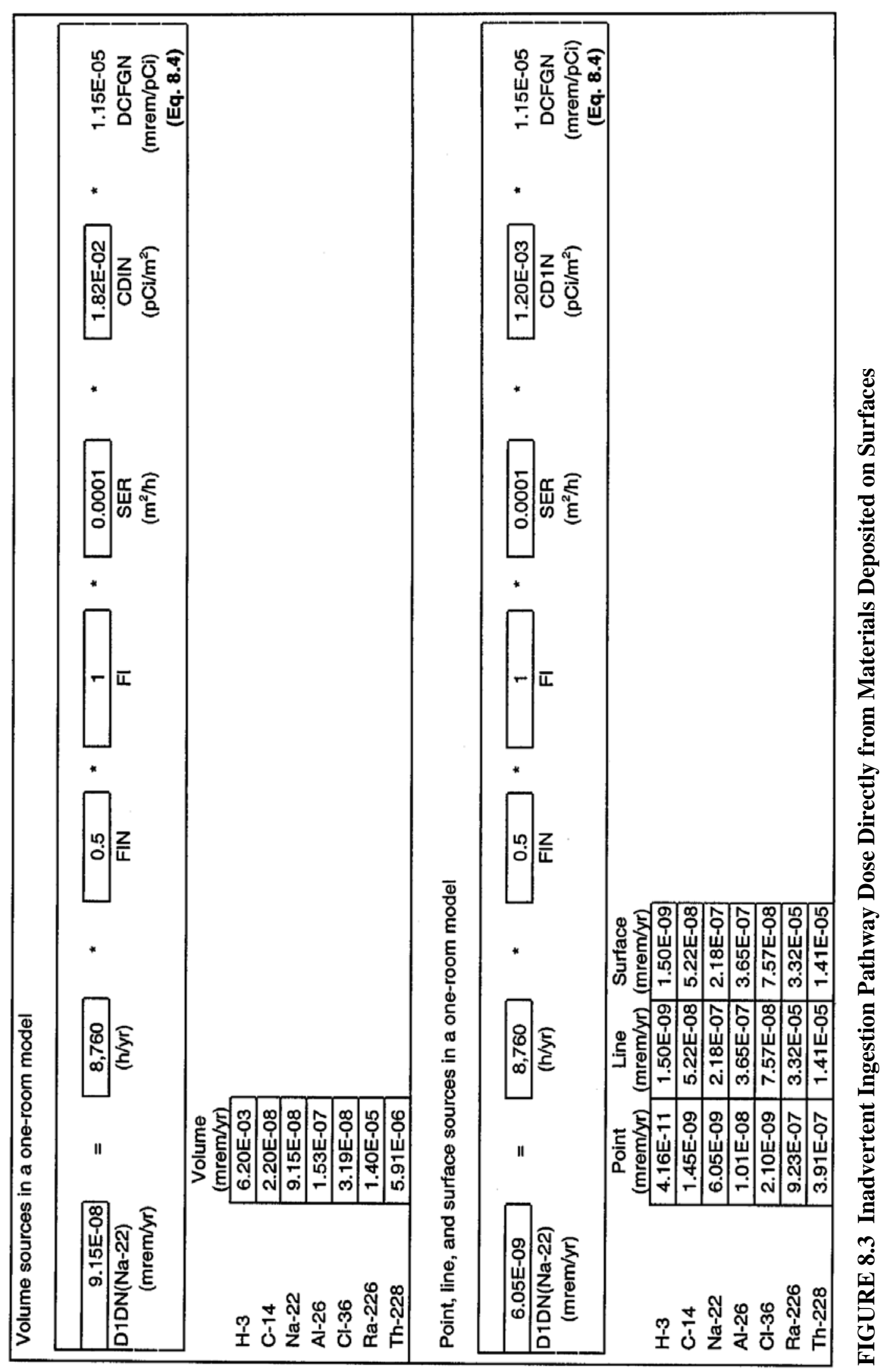


TABLE 8.3 RESRAD-BUILD and Spreadsheet Dose (mrem/yr) Values for the Inadvertent Ingestion of Deposited Material for Three Sets of Input Parameters

\begin{tabular}{|c|c|c|c|c|c|c|}
\hline \multirow[b]{2}{*}{$\begin{array}{l}\text { Source } \\
\text { Type }\end{array}$} & \multicolumn{2}{|c|}{ Default ${ }^{\mathrm{a}}$} & \multicolumn{2}{|c|}{ Lower b } & \multicolumn{2}{|c|}{ Upperc } \\
\hline & $\begin{array}{l}\text { RESRAD- } \\
\text { BUILD }\end{array}$ & Spreadsheet & $\begin{array}{l}\text { RESRAD- } \\
\text { BUILD }\end{array}$ & Spreadsheet & $\begin{array}{l}\text { RESRAD- } \\
\text { BUILD }\end{array}$ & Spreadsheet \\
\hline \multicolumn{7}{|l|}{$\mathrm{Na}-22$} \\
\hline Volume & $9.15 \mathrm{E}-08$ & $9.15 \mathrm{E}-08$ & 0.0 & 0.0 & $1.97 \mathrm{E}-05$ & $1.97 \mathrm{E}-05$ \\
\hline Area & $2.18 \mathrm{E}-07$ & 2.18E-07 & 0.0 & 0.0 & 2.81E-09 & 2.81E-09 \\
\hline Line & $2.18 \mathrm{E}-07$ & 2.18E-07 & 0.0 & 0.0 & 2.81E-09 & 2.81E-09 \\
\hline Point & $6.05 \mathrm{E}-09$ & $6.05 \mathrm{E}-09$ & 0.0 & 0.0 & $7.81 \mathrm{E}-12$ & $7.81 \mathrm{E}-12$ \\
\hline \multicolumn{7}{|l|}{$\mathrm{Al}-26$} \\
\hline Volume & $1.53 \mathrm{E}-07$ & $1.53 \mathrm{E}-07$ & 0.0 & 0.0 & $2.50 \mathrm{E}-05$ & $2.50 \mathrm{E}-05$ \\
\hline Area & 3.65E-07 & $3.65 \mathrm{E}-07$ & 0.0 & 0.0 & 3.57E-09 & 3.57E-09 \\
\hline Line & $3.65 \mathrm{E}-07$ & $3.65 \mathrm{E}-07$ & 0.0 & 0.0 & 3.57E-09 & 3.57E-09 \\
\hline Point & $1.01 \mathrm{E}-08$ & $1.01 \mathrm{E}-08$ & 0.0 & 0.0 & $9.91 \mathrm{E}-12$ & $9.91 \mathrm{E}-12$ \\
\hline \multicolumn{7}{|c|}{ a Inadvertent ingestion of deposited material dose from test case 1.} \\
\hline \multicolumn{7}{|c|}{ b Inadvertent ingestion of deposited material dose from test case 2.} \\
\hline \multicolumn{7}{|c|}{ c Inadvertent ingestion of deposited material dose from test case 3-II. } \\
\hline \multicolumn{7}{|c|}{$\begin{aligned} F_{i}= & \text { fraction of indoor time that is spent at compartment } i \\
& \text { (dimensionless); }\end{aligned}$} \\
\hline \multicolumn{7}{|c|}{$I R=$ inhalation rate $\left(\mathrm{m}^{3} / \mathrm{d}\right)$} \\
\hline \multicolumn{7}{|c|}{$\begin{aligned} C_{i}^{n}(t)= & \text { average concentration of radionuclide } n\left(\mathrm{pCi} / \mathrm{m}^{3}\right) \text { at time } t \text { in the } \\
& \text { indoor air of compartment } i \text {; and }\end{aligned}$} \\
\hline
\end{tabular}

Figure 8.4 shows the spreadsheet calculations for the default parameter set for the volume and area sources. The air concentration, $\mathrm{C} 1 \mathrm{~N}$, in Figure 8.4 is from the calculated air concentration in Figure 3.1 for the volume and area sources. Table 8.4 provides the RESRADBUILD and spreadsheet calculated values of the inhalation pathway doses for the three sets of parameters for the one-room model. The doses were compared for volume, area, line, and point sources. The comparison was performed for Na-22 and Al-26 at time zero. The spreadsheet calculation results were found to match those in the code output. 


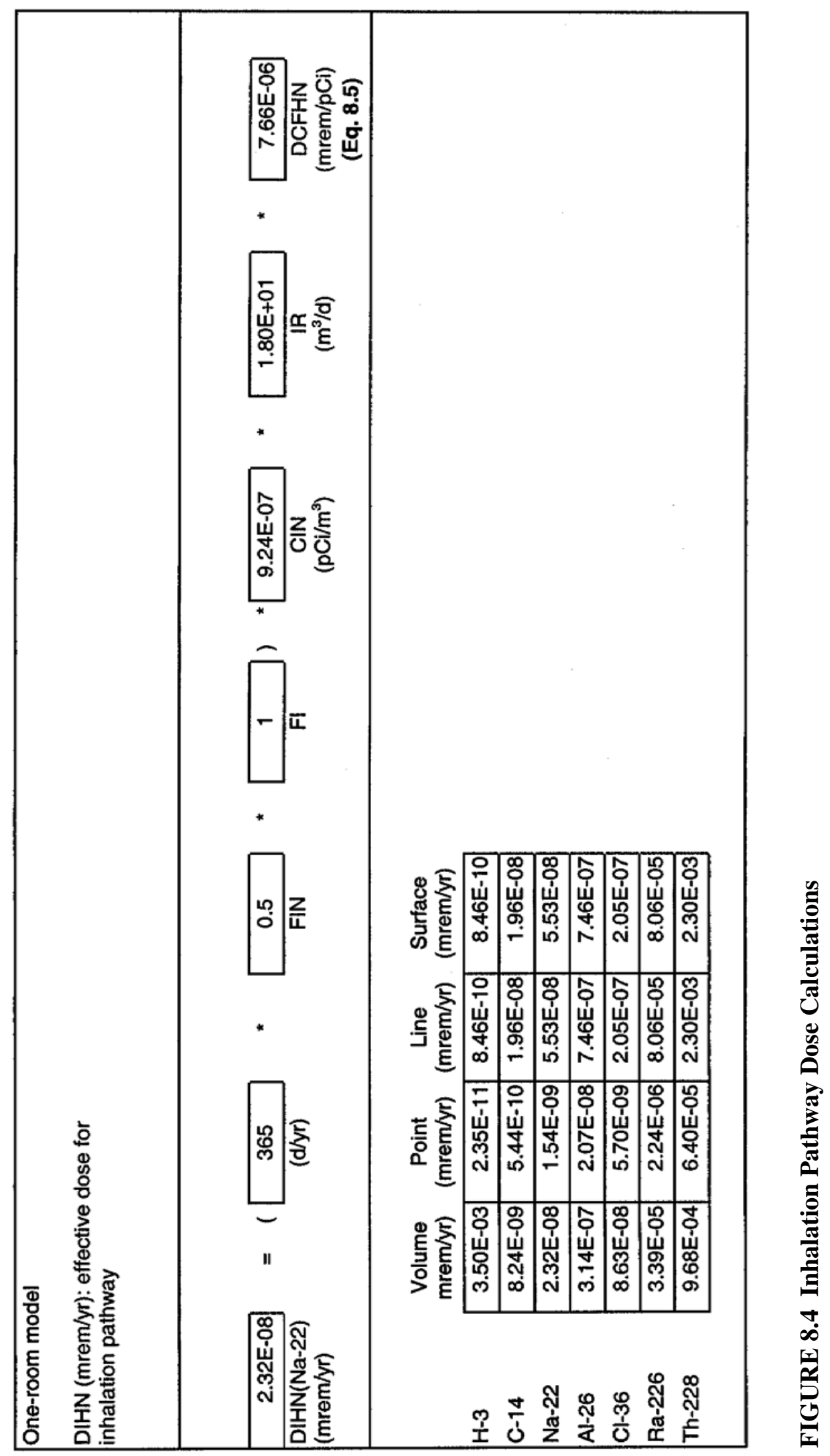


TABLE 8.4 RESRAD-BUILD and Spreadsheet Inhalation Pathway Dose (mrem/yr) Values for Three Sets of Input Parameters

\begin{tabular}{|c|c|c|c|c|c|c|}
\hline \multirow[b]{2}{*}{$\begin{array}{c}\text { Source } \\
\text { Type }\end{array}$} & \multicolumn{2}{|c|}{ Default ${ }^{\mathrm{a}}$} & \multicolumn{2}{|c|}{ Lower ${ }^{\mathrm{b}}$} & \multicolumn{2}{|c|}{ Upperc } \\
\hline & $\begin{array}{l}\text { RESRAD- } \\
\text { BUILD }\end{array}$ & Spreadsheet & $\begin{array}{l}\text { RESRAD- } \\
\text { BUILD }\end{array}$ & Spreadsheet & $\begin{array}{l}\text { RESRAD- } \\
\text { BUILD }\end{array}$ & Spreadsheet \\
\hline \multicolumn{7}{|l|}{$\mathrm{Na}-22$} \\
\hline Volume & 2.32E-08 & 2.32E-08 & $4.58 \mathrm{E}-11$ & $4.58 \mathrm{E}-11$ & $9.06 \mathrm{E}-05$ & $9.06 \mathrm{E}-05$ \\
\hline Area & $5.53 \mathrm{E}-08$ & $5.53 \mathrm{E}-08$ & $2.61 \mathrm{E}-10$ & $2.61 \mathrm{E}-10$ & $1.29 \mathrm{E}-08$ & $1.29 \mathrm{E}-08$ \\
\hline Line & $5.53 \mathrm{E}-08$ & $5.53 \mathrm{E}-08$ & $2.61 \mathrm{E}-10$ & $2.61 \mathrm{E}-10$ & $1.29 \mathrm{E}-08$ & $1.29 \mathrm{E}-08$ \\
\hline Point & $1.54 \mathrm{E}-09$ & $1.54 \mathrm{E}-09$ & $7.25 \mathrm{E}-11$ & $7.25 \mathrm{E}-11$ & $3.59 \mathrm{E}-11$ & $3.59 \mathrm{E}-11$ \\
\hline \multicolumn{7}{|l|}{ Al-26 } \\
\hline Volume & $3.14 \mathrm{E}-07$ & $3.14 \mathrm{E}-07$ & $4.76 \mathrm{E}-10$ & $4.76 \mathrm{E}-10$ & $9.42 \mathrm{E}-04$ & $9.42 \mathrm{E}-04$ \\
\hline Area & $7.46 \mathrm{E}-07$ & $7.46 \mathrm{E}-07$ & 2.71E-09 & 2.71E-09 & $1.34 \mathrm{E}-07$ & $1.34 \mathrm{E}-07$ \\
\hline Line & $7.46 \mathrm{E}-07$ & $7.46 \mathrm{E}-07$ & $2.71 \mathrm{E}-09$ & $2.71 \mathrm{E}-09$ & $1.34 \mathrm{E}-07$ & $1.34 \mathrm{E}-07$ \\
\hline Point & 2.07E-08 & $2.07 \mathrm{E}-08$ & $7.54 \mathrm{E}-10$ & 7.54E-10 & $3.73 \mathrm{E}-10$ & $3.73 \mathrm{E}-10$ \\
\hline \multicolumn{7}{|c|}{ a Inhalation pathway dose from test case 1.} \\
\hline \multicolumn{7}{|c|}{ b Inhalation pathway dose from test case 2 . } \\
\hline c Inhalat & way do & test case 3 . & & & & \\
\hline
\end{tabular}

\subsection{DOSE FROM INHALATION OF AEROSOL INDOOR RADON PROGENY}

Table 8.5 provides the RESRAD-BUILD and spreadsheet calculated values of the radon inhalation pathway doses for the three sets of parameters for the one-room model. The doses were compared for volume and point sources. For surface, area, and point sources, dose only depends on the total source concentration, irrespective of the source type. The comparison was performed for Ra-226 and Th-228 at time zero to check the doses from Rn-222 and Rn-220 progeny. Figure 8.5 shows the spreadsheet calculations for the radon inhalation pathway dose with the default parameter set for the volume and point sources. Good agreement, to within $1 \%$, was obtained between the code output and the verification check.

\subsection{DIRECT EXTERNAL EXPOSURE}

To compare doses from direct external exposure, it was assumed that the sources were infinite in lateral extent. The dose from different types of sources that include area and material factor, off-set factor, and depth-and-cover factor was compared with MCNP results in Section 7. Figure 8.6 shows how the doses for the external pathway were calculated for volume and area sources. The calculated results for the volume source were for a large area source (area 
TABLE 8.5 RESRAD-BUILD and Spreadsheet Radon Inhalation Pathway Dose (mrem/yr) Values for Ra-226 and Th-228 Sources for Three Sets of Input Parameters

\begin{tabular}{|c|c|c|c|c|c|c|}
\hline \multirow[b]{2}{*}{$\begin{array}{c}\text { Source } \\
\text { Type }\end{array}$} & \multicolumn{2}{|c|}{ Default ${ }^{\mathrm{a}}$} & \multicolumn{2}{|c|}{ Lowerb } & \multicolumn{2}{|c|}{ Upperc $^{\mathrm{c}}$} \\
\hline & $\begin{array}{l}\text { RESRAD- } \\
\text { BUILD }\end{array}$ & Spreadsheet & $\begin{array}{l}\text { RESRAD- } \\
\text { BUILD }\end{array}$ & Spreadsheet & $\begin{array}{l}\text { RESRAD- } \\
\text { BUILD }\end{array}$ & Spreadsheet \\
\hline \multicolumn{7}{|l|}{ Ra-226 } \\
\hline Volume & 2.27 & 2.27 & 3.00 & 3.00 & 42.4 & 42.4 \\
\hline Point & $8.75 \mathrm{E}-08$ & 8.74E-08 & 4.17E-06 & 4.16E-06 & 4.91E-08 & 4.91E-08 \\
\hline \multicolumn{7}{|l|}{ Th-228 } \\
\hline Volume & 17.1 & 16.7 & 32.4 & 31.7 & 3,460 & 3,390 \\
\hline Point & $1.29 \mathrm{E}-06$ & $1.27 \mathrm{E}-06$ & $9.22 \mathrm{E}-05$ & $9.04 \mathrm{E}-05$ & $5.73 \mathrm{E}-06$ & $5.61 \mathrm{E}-06$ \\
\hline \multicolumn{7}{|c|}{ a Radon inhalation pathway dose from test case 7.} \\
\hline \multicolumn{7}{|c|}{ b Radon inhalation pathway dose from test case 8.} \\
\hline c Radon in & ation nathwar & dose from tes & & & & \\
\hline
\end{tabular}

factor $=1)$, with the receptor at $1 \mathrm{~m}$ from the center of the 15 -cm-thick source $\left(F_{\text {OFF-SET }}=1\right)$. Table 8.6 provides the RESRAD-BUILD and spreadsheet calculated values of the direct external pathway doses for the three sets of parameters (source was of infinite lateral extent). For external exposure only, the source, receptor, and shielding characteristics are required. The receptor is always at a 1-m height from the source for these comparisons. There is no shielding between the source and receptor for the area sources. Good agreement, to within $2 \%$, was obtained between the code output and the spreadsheet verification.

\subsection{EXTERNAL EXPOSURE TO DEPOSITED MATERIALS}

To compare doses from external exposure to deposited materials, it was assumed that the floor area was infinite in lateral extent (to avoid calculation of the area factor) and that the receptor was at a height of $1 \mathrm{~m}$ from the deposited source (a large floor area of 1,000,000 $\mathrm{m}^{2}$ ). The doses were calculated similar to the direct exposure from area sources. The source concentration was calculated from the deposited materials. Figure 8.7 shows the source deposition and the calculated dose from deposition. Table 8.7 provides the comparison for three input parameter sets. For the lower-bound parameter set, the dose from deposited materials was zero because the deposition velocity was zero (no deposition). Calculated doses were found to agree, within 5\%, between the RESRAD-BUILD output and the spreadsheet verification. 


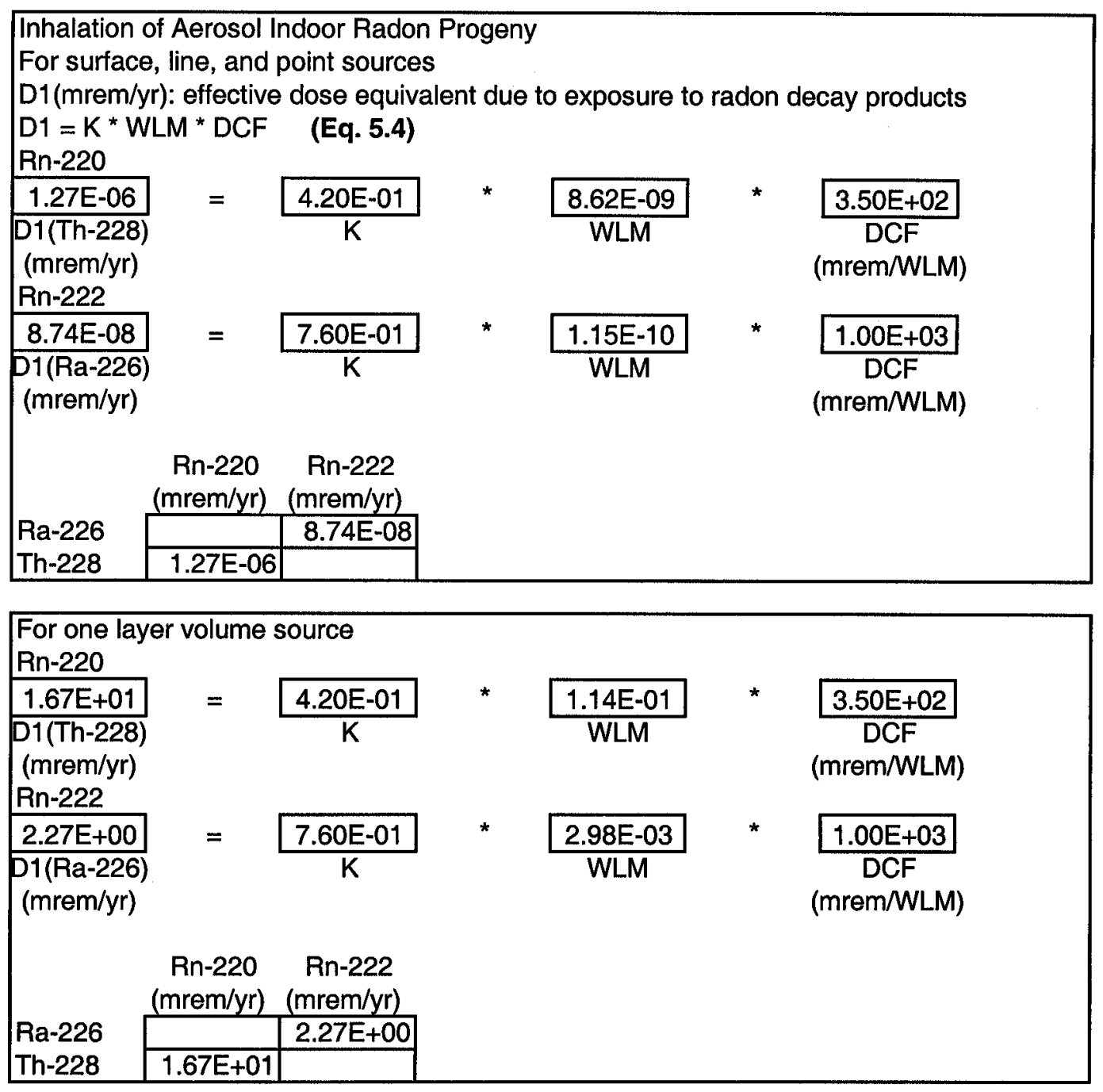

FIGURE 8.5 Radon Pathway Dose Calculations 


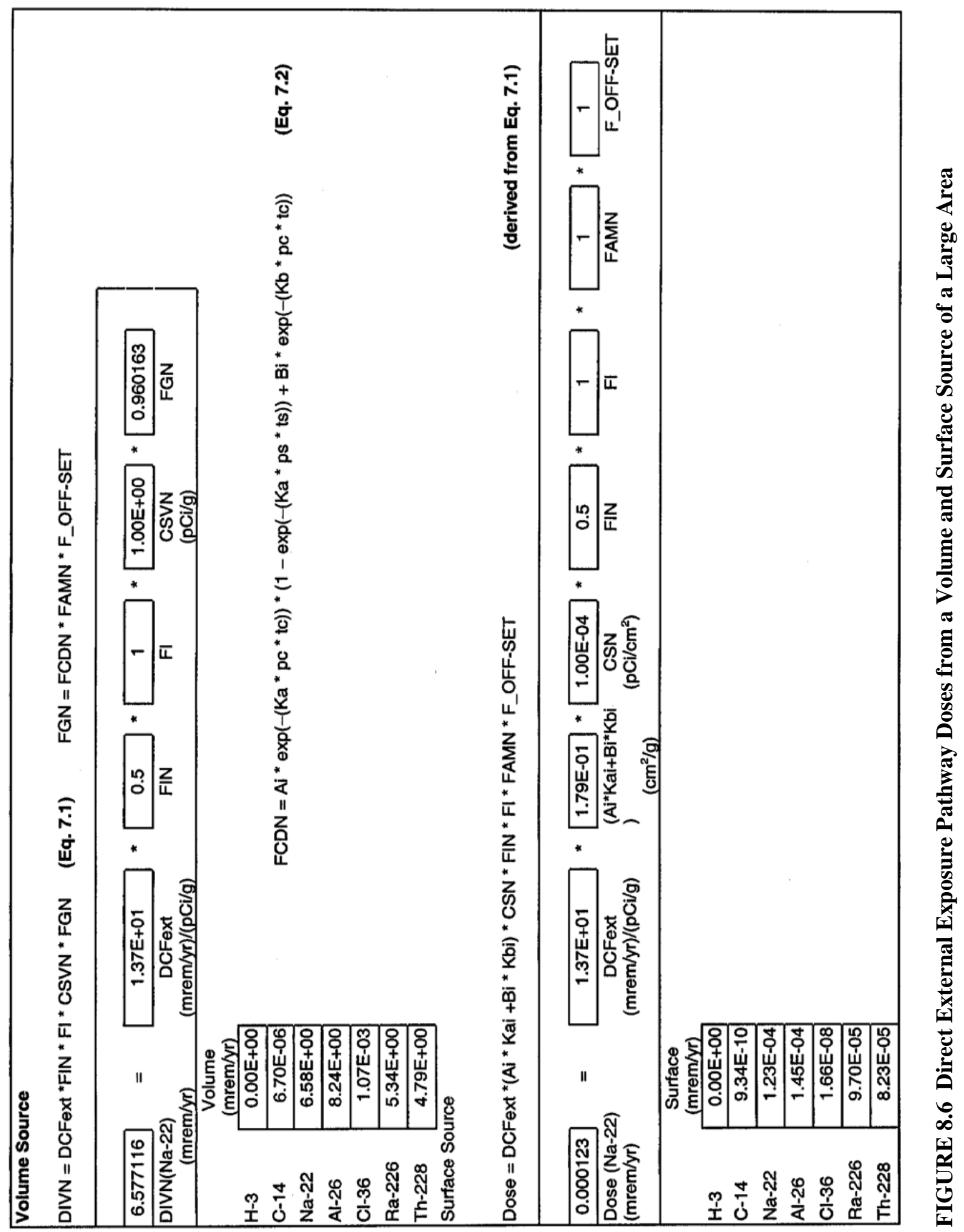


TABLE 8.6 RESRAD-BUILD and Spreadsheet Direct External Exposure Pathway Dose $(\mathrm{mrem} / \mathrm{yr})$ Values for Three Sets of Input Parameters

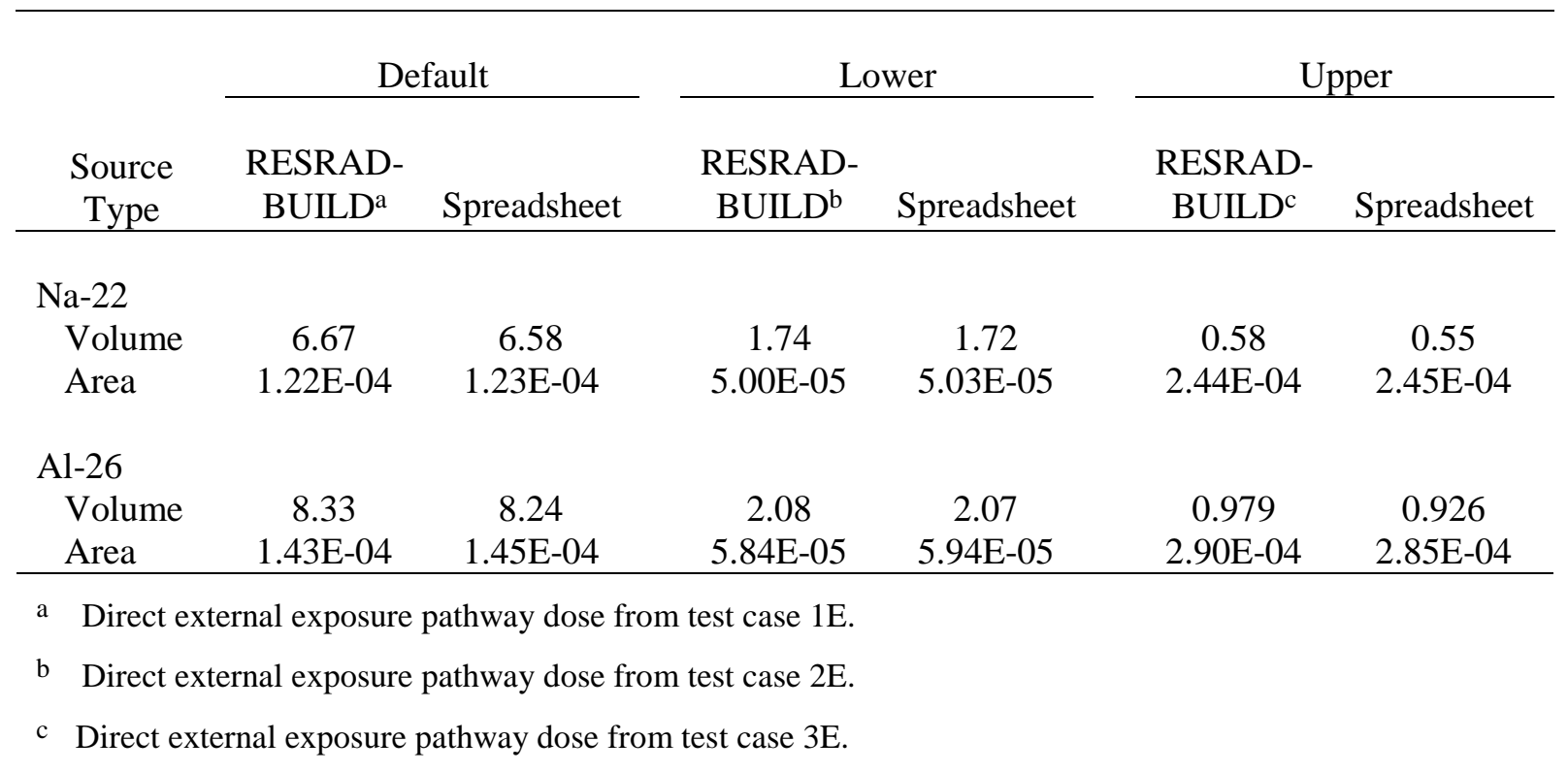

\subsection{TRITIUM VOLUME SOURCE}

Figure 8.8 shows the total injection rate calculated for a tritium volume source. The release rate from tritium evaporation, $q_{\mathrm{H} 3 a v g}$, is from Figure 6.1. The injection rate was used to calculate the tritium air concentration in the room. The tritium air concentration was then used to calculate the inhalation pathway dose and surface deposition. Figure 8.8 shows all the steps involved in these calculations. The indirect ingestion pathway dose was calculated from surface deposition. The direct ingestion pathway calculation is not shown in this figure because the fraction available for evaporation, $f_{r e l}$, is 1 in the default parameter set, which makes the direct ingestion pathway dose equal to zero. The external pathway dose for the tritium source was zero. Table 8.8 shows excellent agreement between the RESRAD-BUILD and the spreadsheet calculated values of the tritium volume source inhalation and ingestion pathway doses for the three sets of parameters for the one-room model. The remaining volatization time shown in Table 8.8 (printed in the RESRAD-BUILD summary report) was the same as the time required for the remaining water to evaporate. Figure 6.1 shows the spreadsheet calculation of remaining volatization time. 


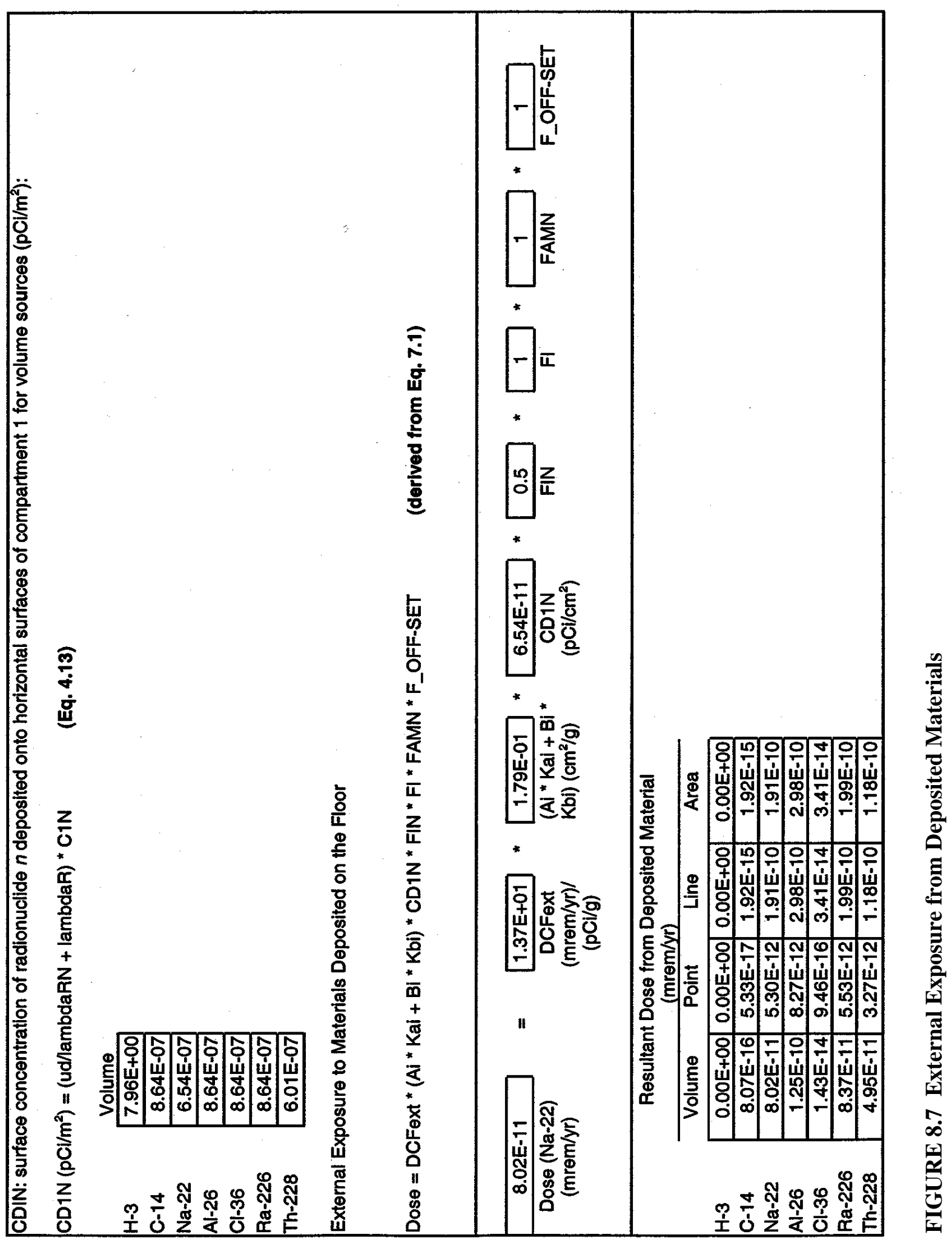


TABLE 8.7 RESRAD-BUILD and Spreadsheet Dose (mrem/yr) Values from the External Exposure of Deposited Material for Three Sets of Input Parameters

\begin{tabular}{|c|c|c|c|c|c|c|}
\hline \multirow[b]{2}{*}{$\begin{array}{c}\text { Source } \\
\text { Type }\end{array}$} & \multicolumn{2}{|c|}{ Default } & \multicolumn{2}{|c|}{ Lower } & \multicolumn{2}{|c|}{ Upper } \\
\hline & $\begin{array}{l}\text { RESRAD- } \\
\text { BUILD }^{\mathrm{a}}\end{array}$ & Spreadsheet & $\begin{array}{l}\text { RESRAD- } \\
\text { BUILD }^{b}\end{array}$ & Spreadsheet & $\begin{array}{l}\text { RESRAD- } \\
\text { BUILD }^{c}\end{array}$ & Spreadsheet \\
\hline \multicolumn{7}{|l|}{$\mathrm{Na}-22$} \\
\hline Volume & $7.74 \mathrm{E}-11$ & $8.02 \mathrm{E}-11$ & 0.0 & 0.0 & $1.51 \mathrm{E}-09$ & $1.57 \mathrm{E}-09$ \\
\hline Area & $1.84 \mathrm{E}-10$ & $1.91 \mathrm{E}-10$ & 0.0 & 0.0 & $2.16 \mathrm{E}-13$ & $2.24 \mathrm{E}-13$ \\
\hline Line & $1.84 \mathrm{E}-10$ & $1.91 \mathrm{E}-10$ & 0.0 & 0.0 & $2.16 \mathrm{E}-13$ & $2.24 \mathrm{E}-13$ \\
\hline Point & $5.11 \mathrm{E}-12$ & $5.30 \mathrm{E}-12$ & 0.0 & 0.0 & $6.00 \mathrm{E}-16$ & $6.22 \mathrm{E}-16$ \\
\hline \multicolumn{7}{|l|}{$\mathrm{Al}-26$} \\
\hline Volume & $1.20 \mathrm{E}-10$ & $1.25 \mathrm{E}-10$ & 0.0 & 0.0 & $1.77 \mathrm{E}-09$ & $1.86 \mathrm{E}-09$ \\
\hline Area & $2.84 \mathrm{E}-10$ & $2.98 \mathrm{E}-10$ & 0.0 & 0.0 & $2.53 \mathrm{E}-13$ & $2.65 \mathrm{E}-13$ \\
\hline Line & $2.84 \mathrm{E}-10$ & $2.98 \mathrm{E}-10$ & 0.0 & 0.0 & $2.53 \mathrm{E}-13$ & $2.65 \mathrm{E}-13$ \\
\hline Point & $7.90 \mathrm{E}-12$ & $8.27 \mathrm{E}-12$ & 0.0 & 0.0 & $7.02 \mathrm{E}-16$ & $7.35 \mathrm{E}-16$ \\
\hline \multicolumn{7}{|c|}{ a External exposure of deposited material dose from test case 1ED. } \\
\hline b External & sposure of dep & sited material & from test cas & $2 \mathrm{ED}$ & & \\
\hline c Extern & osure of de & $\mathrm{m}$ & om test & BED. & & \\
\hline
\end{tabular}

\subsection{TOTAL DOSE AT A RECEPTOR LOCATION}

In RESRAD-BUILD, the total dose received at each receptor location is the sum of all pathway doses at that location. There was no difference between the sum of the individual pathway doses in RESRAD-BUILD and the code calculated total receptor dose.

According to Section 4.3.3.1 of the RESRAD-BUILD manual (Yu et al. 1994), the dose received at a receptor location is the product of the dose rate at the time specified and the time spent at the receptor location. The time spent at a receptor location is the product of three input parameters: total time on-site (exposure duration), fraction of time in the building (indoor fraction), and fraction of time at the receptor location (receptor time in a particular room). The RESRAD-BUILD code output lists the receptor doses received for the exposure duration and the annual dose averaged over exposure duration. If the receptor spends time at two locations in the building, then the total dose for the receptor can be calculated as the sum of the dose at these two locations. 


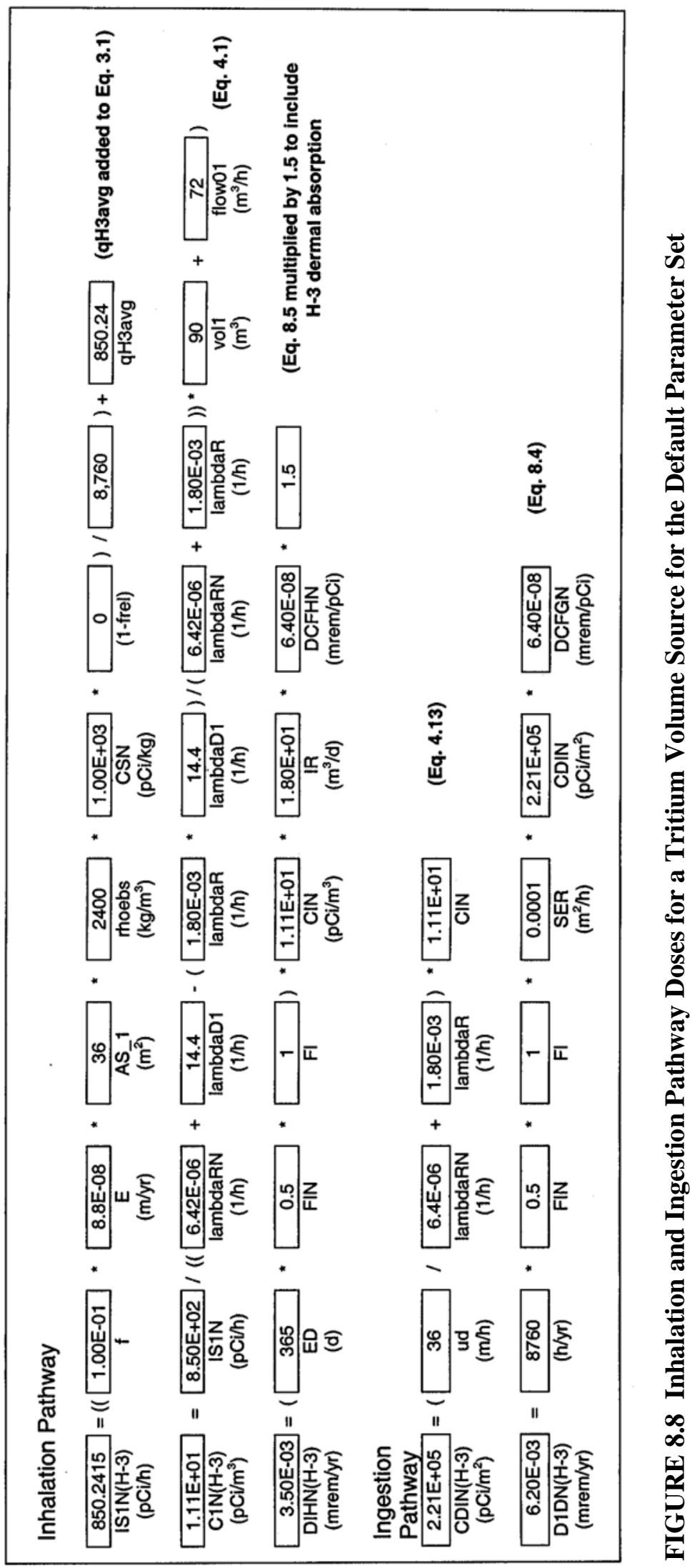


TABLE 8.8 RESRAD-BUILD and Spreadsheet Inhalation and Ingestion Pathway Dose $(\mathrm{mrem} / \mathrm{yr})$ Values for the Tritium Volume Source for Three Sets of Input Parameters

\begin{tabular}{|c|c|c|c|c|c|c|}
\hline \multirow[b]{2}{*}{$\begin{array}{c}\text { Parameter } \\
\text { Set }\end{array}$} & \multicolumn{3}{|c|}{ RESRAD-BUILD } & \multicolumn{3}{|c|}{ Spreadsheet } \\
\hline & Inhalation & $\begin{array}{c}\text { Remaining } \\
\text { Vaporization } \\
\text { Time (yr) }\end{array}$ & Ingestion & Inhalation & $\begin{array}{l}\text { Remaining } \\
\text { Vaporization } \\
\text { Time (yr) }\end{array}$ & Ingestion \\
\hline Default ${ }^{\mathrm{a}}$ & $3.49 \mathrm{E}-03$ & 0.417 & $6.18 \mathrm{E}-03$ & $3.50 \mathrm{E}-03$ & 0.417 & $6.20 \mathrm{E}-03$ \\
\hline Lowerb & $2.83 \mathrm{E}-04$ & 0.0117 & 0.0 & 2.84E-04 & 0.0117 & 0.0 \\
\hline Upper $^{\mathrm{c}}$ & $4.43 \mathrm{E}-03$ & 18.82 & 4.27E-04 & $4.43 \mathrm{E}-03$ & 18.82 & $4.29 \mathrm{E}-04$ \\
\hline
\end{tabular}

The use of exposure duration in the code was checked. The exposure duration for a shortlived $\mathrm{Ra}-228$ volume source was varied from 730 to 36.5 days, and the receptor dose with the default parameter set was calculated. Radium-228 was chosen because it decays to short-lived Th-228, and the dose changes with exposure duration. Table 8.9 lists doses at time zero for different exposure durations, with and without time integration. The time integration takes into account the Th-228 buildup with time, whereas the instantaneous dose (taken at the start of the exposure period) does not account for the buildup. The RESRAD-BUILD code applies the time integration over the exposure duration and uses the dose for exposure duration to calculate the receptor's average yearly dose. Figure 8.9 shows the estimated dose with and without time integration. 
TABLE 8.9 Receptor Dose for Different Exposure Times for the Ra-228 Volume Source

\begin{tabular}{|c|c|c|c|c|}
\hline \multirow[b]{2}{*}{$\begin{array}{c}\text { Exposure } \\
\text { Duration }(\mathrm{d})\end{array}$} & \multicolumn{2}{|c|}{$\begin{array}{l}\text { Receptor Dose for } \\
\text { Exposure Duration }\end{array}$} & \multicolumn{2}{|c|}{$\begin{array}{c}\text { Receptor Yearly Dose } \\
\text { Averaged Over Exposure } \\
\text { Duration }\end{array}$} \\
\hline & $\begin{array}{l}\text { With Time } \\
\text { Integration }^{\mathrm{a}}\end{array}$ & $\begin{array}{l}\text { Without Time } \\
\text { Integration }^{\mathrm{b}}\end{array}$ & $\begin{array}{l}\text { With Time } \\
\text { Integration }^{\mathrm{a}}\end{array}$ & $\begin{array}{l}\text { Without Time } \\
\text { Integration }^{\mathrm{b}}\end{array}$ \\
\hline 36.5 & 0.224 & 0.19 & 2.25 & 1.9 \\
\hline 100 & 0.773 & 0.52 & 2.82 & 1.9 \\
\hline 365 & 4.9 & 1.9 & 4.9 & 1.9 \\
\hline 730 & 14.1 & 3.8 & 7.03 & 1.9 \\
\hline
\end{tabular}

a Test case 14 with varying exposure duration.

b Test case 15 with varying exposure duration.
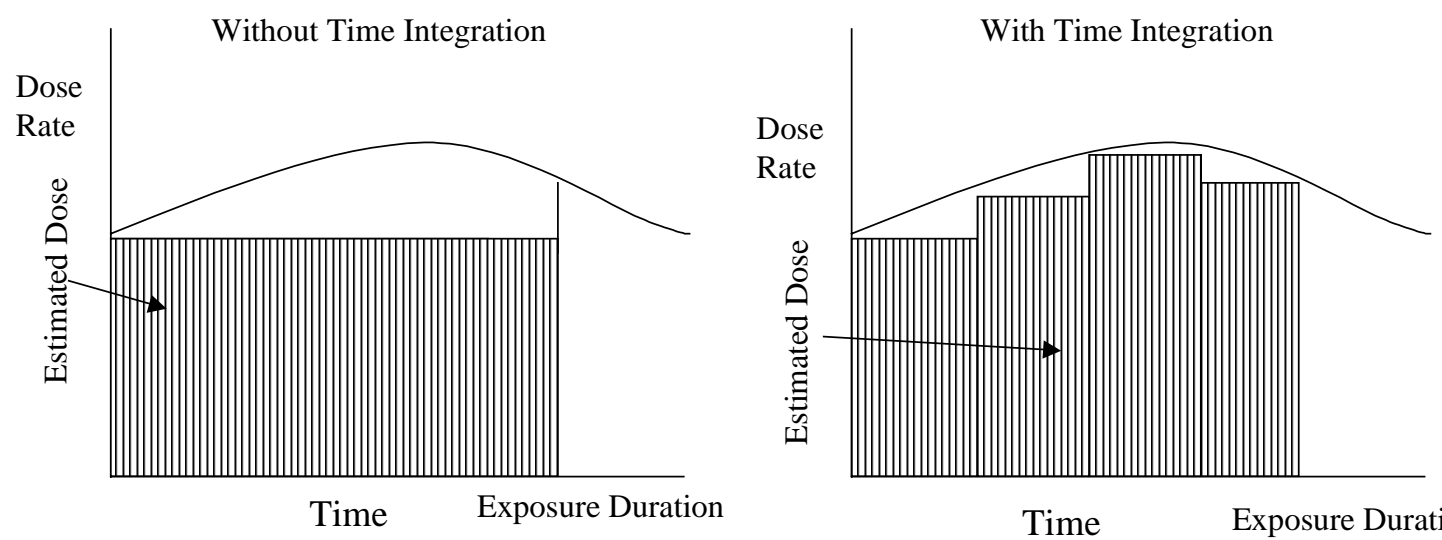

Time

Exposure Duration

FIGURE 8.9 Estimated Dose with and without Time Integration 


\section{TIME DEPENDENCE IN DOSE CALCULATIONS}

This section discusses the time dependence in the dose calculations. In Section 8, pathway doses were always calculated by multiplying the instantaneous dose at time zero by the exposure duration.

\subsection{TIME INTEGRATION IN RESRAD-BUILD}

The RESRAD-BUILD code calculates the time-integrated dose over the exposure duration. The user can specify the number of points for time integration. These points determine the number of time intervals used in the integrations. In version 3.0 of the code, the maximum number of points for time integration is 17.2 This aspect of the code was tested for the short-lived Ra-228 radionuclide, which decays to the short-lived Th-228 radionuclide, and also has a dose contribution from the radon inhalation pathway. First, the time-integrated dose at time zero (at the beginning of assessment), with five time integration points for each pathway, was calculated with the code (case 14). The pathway doses were then compared with the dose calculated at different times $(t=0, t=0.2, t=0.4, t=0.6, t=0.8$, and $t=1.0 \mathrm{yr})$, with one time dose rate calculation (case 15). Table 9.1 presents the comparison of the calculated doses at different times. The RESRAD-BUILD code generated outputs for cases 14 and 15 are provided in the Appendix. For the Ra-228 radionuclide, the calculated dose without time integration is different at $t=0.0, t=0.2, t=0.4, t=0.6, t=0.8$, and $t=1.0$ years; the dose increases because of the progeny (Th-228) buildup. However, no significant difference in the time-integrated and the average individual pathway or total dose (obtained by averaging the dose over different time intervals) was observed.

TABLE 9.1 Calculated Dose (mrem/yr) for the Ra-228 Volume Source with Default Parameters ${ }^{\mathrm{a}}$

\begin{tabular}{lllllllll}
\multicolumn{1}{c}{ Pathway } & $t=$ time-int & $t=0.0 \mathrm{yr}$ & $t=0.2 \mathrm{yr}$ & $t=0.4 \mathrm{yr}$ & $t=0.6 \mathrm{yr}$ & $t=0.8 \mathrm{yr}$ & $t=1.0 \mathrm{yr}$ & $t=$ average \\
\hline & & & & & & & & \\
External & 2.26 & 1.9 & 2.06 & 2.21 & 2.34 & 2.45 & 2.55 & 2.25 \\
Deposition & $2.89 \mathrm{E}-07$ & $2.57 \mathrm{E}-07$ & $2.72 \mathrm{E}-07$ & $2.85 \mathrm{E}-07$ & $2.96 \mathrm{E}-07$ & $3.06 \mathrm{E}-07$ & $3.14 \mathrm{E}-07$ & $2.88 \mathrm{E}-07$ \\
Immersion & $3.41 \mathrm{E}-09$ & $2.95 \mathrm{E}-09$ & $3.16 \mathrm{E}-09$ & $3.35 \mathrm{E}-09$ & $3.51 \mathrm{E}-09$ & $3.65 \mathrm{E}-09$ & $3.77 \mathrm{E}-09$ & $3.40 \mathrm{E}-09$ \\
Inhalation & $1.66 \mathrm{E}-04$ & $1.77 \mathrm{E}-05$ & $8.41 \mathrm{E}-05$ & $1.44 \mathrm{E}-04$ & $1.99 \mathrm{E}-04$ & $2.48 \mathrm{E}-04$ & $2.92 \mathrm{E}-04$ & $1.64 \mathrm{E}-04$ \\
Radon & 2.64 & $4.52 \mathrm{E}-14$ & 1.18 & 2.25 & 3.21 & 4.09 & 4.87 & 2.60 \\
Ingestion & $1.34 \mathrm{E}-05$ & $1.32 \mathrm{E}-05$ & $1.33 \mathrm{E}-05$ & $1.34 \mathrm{E}-05$ & $1.34 \mathrm{E}-05$ & $1.34 \mathrm{E}-05$ & $1.34 \mathrm{E}-05$ & $1.34 \mathrm{E}-05$ \\
Total & 4.90 & 1.90 & 3.24 & 4.46 & 5.55 & 6.54 & 7.42 & 4.85 \\
\hline
\end{tabular}

a The calculated dose for $t=$ time-int is from test case 14; for other times, it is from test case 15 .

\footnotetext{
2 In version 3.1 of the RESRAD-BUILD code, the maximum number of integration points has been increased.
} 


\subsection{TIME DEPENDENCE OF SOURCE CHARACTERISTICS IN DOSE}

The source characteristics change with time because of radioactive decay and in-growth, source erosion, and source life time. The source characteristics that change with time are radionuclide concentration; thickness for a volume source; removable fraction for area, line, and point sources; and dry zone thickness in the case of the tritium volume source. The removable fraction at times later than the source lifetime is zero, which makes the source injection rate equal to zero for area, line, and point sources. Therefore, the air concentration and all pathway doses, except for radon inhalation and direct external exposure pathways, would be zero at that time. This aspect of the code was tested with Co-60, Ra-226, and U-238 sources and was found to be working correctly.

The source erosion rate changes the source thickness with time, which in turn affects the calculated dose for radon and direct external exposure pathway. To test this aspect of the code, the dose was calculated for the Ra-226 volume source of a large area $\left(100,000 \mathrm{~m}^{2}\right)$, with a source erosion rate of $4.8 \mathrm{E}-3 \mathrm{~cm} / \mathrm{d}$ at different evaluation times ( $t=0,1,2,3,4,5,6,7$, and 8 years). The radionuclide concentration will change because of radionuclide decay, but should not depend on source thickness. The change in the Ra-226 concentration because of radioactive decay in 8 years (Ra-226 half-life $=1,600$ years) will be less than $0.4 \%$. The Ra-226 concentration values printed in the summary report in this case (source erosion rate $=4.8 \mathrm{E}-3 \mathrm{~cm} / \mathrm{d}$ ) changed from $1 \mathrm{pCi} / \mathrm{g}$ at time $=0$ years to $0.06474 \mathrm{pCi} / \mathrm{g}$ at time $=8$ years. Table 9.2 shows the Ra-226 concentration printed in the summary report at different times. It appears that change in radionuclide concentration is related to change in source thickness. Table 9.2 shows the source thickness printed in the summary report at different times. However, the calculated pathway doses appear to be correct. The reporting of the incorrect radionuclide concentration in the summary report, which is not used in dose calculations, should be corrected. Table 9.2 shows the RESRAD-BUILD results and compares the external and radon inhalation dose with the results from the spreadsheet calculations. The summary report associated with Case 16 is in the Appendix.

The radioactive decay and in-growth would change the source concentration and would affect all pathways proportionately. This aspect of the code was tested with the U-238 radionuclide, a long-decay chain radionuclide, and the Ra-228 radionuclide, a short half-life (5.76 years) radionuclide that decays to Th-228, which is another short half-life (1.9131 years) radionuclide. The U-238 radionuclide (half-life $=4.468 \mathrm{E}+09$ years) decays to the U-234 radionuclide (half-life $=2.45 \mathrm{E}+05$ years), which decays to the Th-230 radionuclide (half-life $=$ $8.0 \mathrm{E}+04$ years), which decays to the Ra-226 radionuclide (half-life $=1.6 \mathrm{E}+03$ years), which decays to the $\mathrm{Pb}-210$ radionuclide (half-life $=22.3$ years), which decays to the stable $\mathrm{Pb}-206$ nuclide. In all, there are four associated radionuclides (U-234, Th-230, Ra-226, and Pb-210) in the U-238 decay chain. All the associated radionuclides in the chain (decay chain radionuclides with a half-life less than six months) were not included in the discussion above. First the radionuclide concentration calculations for the progeny radionuclides were checked, and then it was determined whether the dose contribution from the progeny had been added in the total dose. 


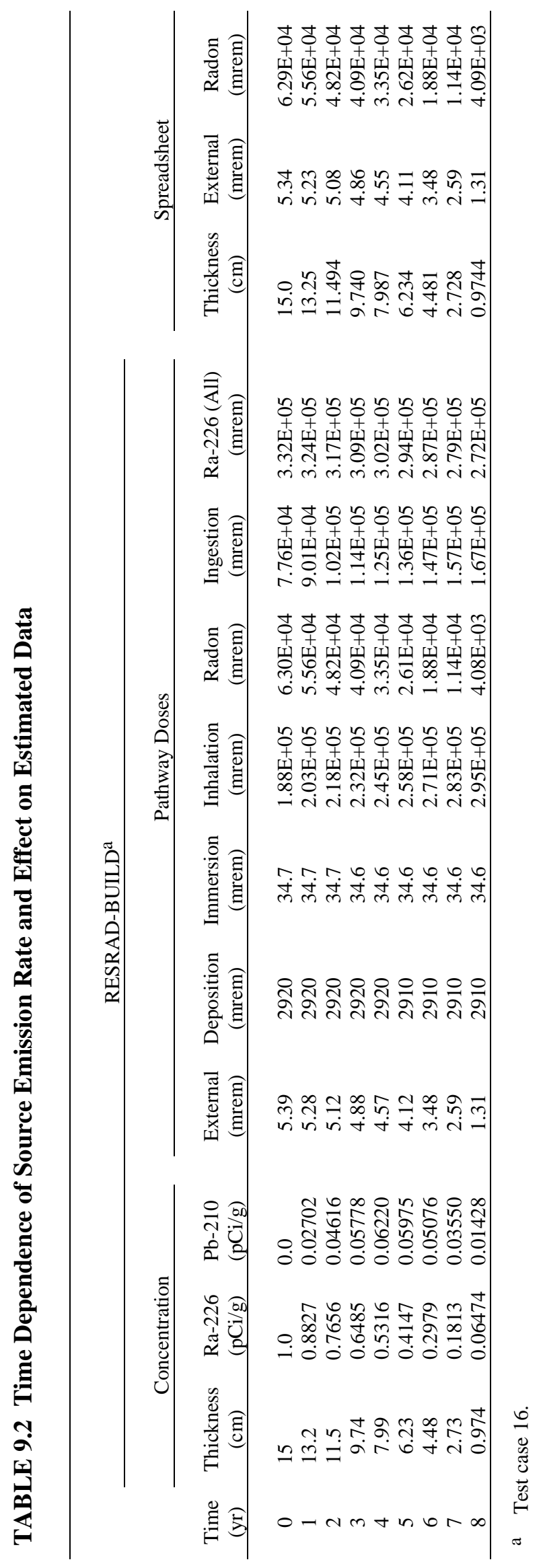


The radionuclide concentrations calculated by RESRAD-BUILD (case 17) were compared with the concentrations calculated by the RESRAD code (testbd.rad). For this comparison, radionuclide concentrations were calculated at time $0,1,3,10,30,100,300$, and 1,000 years by using both codes (RESRAD and RESRAD-BUILD). In RESRAD, to avoid leaching from the contaminated zone, high distribution coefficient values were used for the principal and progeny radionuclides, and the radionuclide concentrations calculated at different times were taken from the concentration report (concent.rpt). In RESRAD-BUILD, calculations were performed with one time integration point for a volume source with no erosion. Table 9.3 presents the results of the comparison of the radionuclide concentrations obtained with the two codes. Results generated from the RESRAD-BUILD and RESRAD runs are provided in the Appendix. Concentrations for Ra-228 and its progeny, Th-228, were exactly the same in both codes. Concentrations for U-238 and its progeny - U-234, Th-230, and Ra-226 - were also the same in both codes. However, the concentrations of $\mathrm{Pb}-210$ (the last progeny in the U-238 decay chain) were different at $t=1$ and $t=3$ years. RESRAD-BUILD gives the $\mathrm{Pb}-210$ concentration as zero at $t=1$ year, compared with the value of $1.42 \mathrm{E}-17$ given by RESRAD. At $t=3$ years, $\mathrm{Pb}-210$ concentrations were slightly different (RESRAD-BUILD 1.07E-15, compared with 1.14E-15 in RESRAD); at other times, values were the same in both codes. To check whether the dose contribution from the progeny was calculated properly or not, the dose at the reported concentration at later times was input as the concentration at $t=0$ time, and the calculated doses were compared in two cases; the results were the same.

TABLE 9.3 Calculated Radionuclide Concentrations (pCi/g) at Different Times in the RESRAD-BUILD and RESRAD Codes for an Initial Parent Concentration of 1 pCi/g

\begin{tabular}{|c|c|c|c|c|c|c|c|c|}
\hline Radionuclide & $t=0 \mathrm{yr}$ & $t=1 \mathrm{yr}$ & $t=3 \mathrm{yr}$ & $t=10 \mathrm{yr}$ & $t=30 \mathrm{yr}$ & $t=100 \mathrm{yr}$ & $t=300 \mathrm{yr}$ & $t=1,000 \mathrm{yr}$ \\
\hline \multicolumn{9}{|c|}{ RESRAD-BUILD ${ }^{\mathrm{a}}$} \\
\hline $\mathrm{U}-238$ & 1.0 & 1.0 & 1.0 & 1.0 & 1.0 & 1.0 & 1.0 & 1.0 \\
\hline U-234 & 0.0 & $2.84 \mathrm{E}-6$ & $8.51 \mathrm{E}-6$ & $2.84 \mathrm{E}-5$ & $8.51 \mathrm{E}-5$ & $2.84 \mathrm{E}-4$ & $8.50 \mathrm{E}-4$ & $2.83 \mathrm{E}-3$ \\
\hline Th-230 & 0.0 & $1.28 \mathrm{E}-11$ & $1.15 \mathrm{E}-10$ & $1.28 \mathrm{E}-9$ & $1.15 \mathrm{E}-8$ & $1.28 \mathrm{E}-7$ & $1.15 \mathrm{E}-6$ & $1.27 \mathrm{E}-5$ \\
\hline Ra-226 & 0.0 & $1.85 \mathrm{E}-15$ & $4.97 \mathrm{E}-14$ & $1.84 \mathrm{E}-12$ & $4.96 \mathrm{E}-11$ & $1.82 \mathrm{E}-9$ & $4.81 \mathrm{E}-8$ & $1.65 \mathrm{E}-6$ \\
\hline $\mathrm{Pb}-210$ & 0.0 & 0.0 & $1.07 \mathrm{E}-15$ & $1.35 \mathrm{E}-13$ & $9.70 \mathrm{E}-12$ & $8.49 \mathrm{E}-10$ & $3.57 \mathrm{E}-8$ & $1.51 \mathrm{E}-6$ \\
\hline $\mathrm{Ra}-228$ & 1.0 & 0.8864 & 0.6965 & 0.2996 & 0.02688 & $5.82 \mathrm{E}-6$ & $1.97 \mathrm{E}-16$ & 0.0 \\
\hline Th-228 & 0.0 & 0.2853 & 0.5384 & 0.4089 & 0.04025 & $8.72 \mathrm{E}-6$ & $2.95 \mathrm{E}-16$ & 0.0 \\
\hline \multicolumn{9}{|c|}{ RESRAD $^{\mathrm{b}}$} \\
\hline $\mathrm{U}-238$ & 1.0 & 1.0 & 1.0 & 1.0 & 1.0 & 1.0 & 1.0 & 1.0 \\
\hline U-234 & 0.0 & $2.84 \mathrm{E}-6$ & $8.51 \mathrm{E}-6$ & $2.84 \mathrm{E}-5$ & $8.50 \mathrm{E}-5$ & $2.84 \mathrm{E}-4$ & $8.50 \mathrm{E}-4$ & $2.83 \mathrm{E}-3$ \\
\hline Th-230 & 0.0 & $1.28 \mathrm{E}-11$ & $1.15 \mathrm{E}-10$ & $1.28 \mathrm{E}-9$ & $1.15 \mathrm{E}-8$ & $1.28 \mathrm{E}-7$ & $1.15 \mathrm{E}-6$ & $1.27 \mathrm{E}-5$ \\
\hline Ra-226 & 0.0 & $1.84 \mathrm{E}-15$ & $4.97 \mathrm{E}-14$ & $1.84 \mathrm{E}-12$ & $4.96 \mathrm{E}-11$ & $1.82 \mathrm{E}-9$ & $4.81 \mathrm{E}-8$ & $1.65 \mathrm{E}-6$ \\
\hline $\mathrm{Pb}-210$ & 0.0 & $1.42 \mathrm{E}-17$ & $1.14 \mathrm{E}-15$ & $1.35 \mathrm{E}-13$ & $9.70 \mathrm{E}-12$ & $8.49 \mathrm{E}-10$ & $3.57 \mathrm{E}-8$ & $1.51 \mathrm{E}-6$ \\
\hline Ra-228 & 1.0 & 0.8864 & 0.6965 & 0.2995 & 0.02688 & $5.82 \mathrm{E}-6$ & $1.97 \mathrm{E}-16$ & 0.0 \\
\hline Th-228 & 0.0 & 0.2853 & 0.5384 & 0.4089 & 0.04025 & $8.72 \mathrm{E}-6$ & $2.95 \mathrm{E}-16$ & 0.0 \\
\hline
\end{tabular}




\section{CONCLUSIONS}

For RESRAD-BUILD verification, a Microsoft ${ }^{\circledR}$ Excel spreadsheet was prepared to perform the calculations. In some cases, computer codes such as MCNP and RESRAD also were used to benchmark RESRAD-BUILD results. Table 10.1 summarizes the findings and conclusions for the calculations investigated. Verification also confirmed that the calculated dose for all pathways, except direct external exposure, does not depend on source receptor location or the shielding characteristics as long as the source and receptor are in the same room.

The following findings/problems were identified in the process of verifying the RESRAD-BUILD code and the summary report.

- Help needs to be updated because it is not available for certain parameters (e.g., time integration points, evaluation time, flow rates between rooms, etc.).

- The nucdcf.dat file contains DCFs for ingestion, inhalation, external-surface, external-volume, and immersion pathways. It also includes half-lives, total number of gammas emitted, and the number of branching radionuclides. The values of external-surface and external-volume DCFs from this file are not used in the dose calculations; therefore, those values may be removed from the nucdcf.dat file. The values of half-lives have only three significant digits. The significant digits should be increased to match the actual half-lives.

- The last digit of the half-life is not correct for Zn-65 and Ac-227. The half-life for $\mathrm{Zn}-65$ should be changed from $6.67 \mathrm{E}-01$ to $6.68 \mathrm{E}-01$ years, and the half-life for Ac-227 should be changed from 2.17E+01 to 2.18E+01 years.

- The inhalation DCFs for Ce-144 and Pm-147 are not correct. The Ce-144 inhalation DCF should be changed from 2.16E-04 to 3.74E-04, and the Pm-147 inhalation DCF should be changed from 2.58E-05 to 3.92E-05.

- The coeff_bd.lib file contains parameters required to compute the external pathway dose for surface and volume sources. The parameters are external DCFs for volume source, fitted coefficients of the external exposure model, collapsed gamma energies, and respective gamma fractions of radionuclides. The file has only two significant digits for some of the external exposure model parameters. The significant digits should be increased to three to get a better fit.

- In the RESRAD-BUILD summary report, the value for removable fraction at assessment times appears as 0.0, rather than the correct value. 


\section{TABLE 10.1 Conclusions on Types of Calculations Investigated}

Type of Calculation Conclusions

Input parameter

check

Source injection rate

Air concentration in the room

Air particulate deposition

Radon pathway model

Tritium model for volume source

External exposure model

Different pathway doses

Time dependence in dose calculations
The parameters checked included inhalation, ingestion, air submersion, and external DCFs; external exposure model parameters; and radionuclide half-lives and other decay data. Some discrepancies found in parameter values were later corrected.

Excellent agreement was obtained between the RESRAD-BUILD generated results and spreadsheet calculations.

Air concentrations for four source types were compared for one- and two-room air quality models. Excellent agreement was obtained between the RESRAD-BUILD and spreadsheet calculations.

Air particulate deposition was computed because it is used in two pathways: external exposure due to deposited material and inadvertent ingestion directly from the deposited materials. No discrepancy was found in inadvertent pathway doses; therefore, air particulate deposition is computed correctly in the code.

The calculations checked were the radon injection rate and the radon progeny concentration. For the point, line, and area sources, there was no difference in the RESRAD-BUILD and spreadsheet calculations of the source injection rates. However, the volume source injection rates for Rn-222 and Rn-220 were different in two cases. The difference is due to the density used in the calculations. For the spreadsheet calculations, it was assumed that the particle density is input; in RESRAD-BUILD, the source bulk density was assumed. If the same density values are used in RESRADBUILD, the results are the same (within round-off errors) as the spreadsheet calculations. No significant differences in the RESRAD-BUILD and spreadsheet calculations were observed in radon progeny concentrations.

The tritium-transport model in RESRAD-BUILD for a volume source estimates the injection rate of tritiated water molecules into the indoor air from evaporation; this injection rate is then added to the source injection from erosion to calculate the total source injection. This sum source injection rate is then used to calculate air concentration, air deposition, etc. No inconsistencies between the code output and spreadsheet calculations were obtained for the injection rate of tritiated water molecules.

In the RESRAD-BUILD code, two direct exposure models based on the source geometry are used. The first model for area and volume sources is based on a semiinfinite slab source with corrections for geometric factors. The second model for point and line contamination is a simple dose integral method. The results of the external models were compared with those from the MCNP transport code. The comparisons were performed at different source-receptor configurations for Co-60, Mn-54, and Au-95. Good agreement (within 5\%) was observed.

The different pathway doses calculated by the RESRAD-BUILD code were compared with the spreadsheet calculations. No inconsistencies between the code output and spreadsheet calculations were obtained for submersion, direct inadvertent ingestion, inadvertent ingestion of deposited materials, inhalation of airborne radioactive particulates, and tritium volume source. For inhalation of aerosol indoor radon progeny, good agreement, to within $1 \%$, was obtained. For direct external exposure, good agreement to within $2 \%$, and for external exposure to deposited material, agreement within $5 \%$ was observed. There was no difference in the spreadsheet calculated total receptor dose and the code calculated total receptor dose.

No significant differences in the time-integrated and the average individual pathway dose (obtained by averaging the dose over different time intervals) were obtained. 
- The full file name does not print in the summary report if the file name is longer than six digits (e.g., site1111.inp appears as site1111.i).

- The way the dose is calculated for a multiwall-region volume source is confusing (e.g., the receptor was fixed at 1,1,1, a five-region volume source was selected, and the source location was changed from 0.99, 0.99, 0.99 to $1.01,1.01,1.01$, with only the Co-60 radionuclide selected and with all default wall region parameters). The calculated dose was changed from $5.51 \mathrm{mrem} / \mathrm{yr}$ to $3.65 \mathrm{E}-5 \mathrm{mrem} / \mathrm{yr}$. Previously, there did not appear to be any shielding between the source and receptor, but in later cases there was a shielding thickness of $60 \mathrm{~cm}(15+15+15+15=60 \mathrm{~cm}$ from four regions was assumed.)

- Radon pathway doses appear to include the flux from both sides of the source, and the density parameter is not used properly (see Section 5 for more explanation).

- The source erosion rate should change source thickness, which should affect the calculated dose for radon and the direct external exposure pathway. To test this aspect of the code, the dose was calculated for a Ra-226 volume source with different source erosion rates. The source thickness printed in the summary report shows the correct changes due to source erosion. The calculated pathway doses appear to be correct. However, the radionuclide concentration printed in the summary report is not correct.

- Radionuclide decay and in-growth calculations in the code were tested with a $\mathrm{U}-238$ source. The radionuclide concentration for $\mathrm{Pb}-210$ progeny was found to be zero at $t=1$ year (see Section 9 for a better description of the problem).

- In the RESRAD-BUILD output report, the table of contents is not comprehensive.

- Inconsistencies exist in the units used in the interface and in the report (e.g., g and gm, h and hr, etc.)

- Inconsistencies exist in the parameter names used in the interface and the report (e.g., exposure duration and total time, indoor fraction and fraction inside, wet + dry zone thickness and total thickness, water fraction available for vaporization and volatization fraction, total porosity of contaminated material and wall total porosity, etc.) 
- For the multiwall-region volume source, if the first layer is eroded, source information for the number of regions and the contaminated region is not modified in the report.

- External DCFs used in the external exposure model in the code are in units of $\mathrm{mrem} / \mathrm{yr}$ per $\mathrm{pCi} / \mathrm{g}$; the $\mathrm{DCF}$ in the report is in units of $\mathrm{mrem} / \mathrm{yr}$ per $\mathrm{pCi} / \mathrm{m}^{3}$. The default source density in the code is $2.4 \mathrm{~g} / \mathrm{cm}^{3}$ for the volume source, whereas the reported DCF value has a density of $1.6 \mathrm{~g} / \mathrm{cm}^{3}$. 


\section{VERIFICATION LIMITATIONS AND SUGGESTIONS FOR IMPROVEMENT}

Verification was limited to an initial check of input parameters and spot-checks of major portions of the code by using carefully selected radionuclides. Verification of the code interface, uncertainty analysis, and all combinations of input values was not performed in this exercise. The verification of the uncertainty analysis was documented in Kamboj et al. (2000). During the verification process, the following suggestions were made for future improvement of the RESRAD-BUILD code:

- Input and default parameter values and intermediate and complete final results should be stored and made accessible for further verification and processing;

- Input template files should be provided for typical exposure scenarios;

- Specifications on volume source regions and their relationships to the receptor should be improved; and

- An independent and comprehensive verification of the code interface and all combinations of input parameter values for all pathways should be performed. 


\section{REFERENCES}

Briesmeister, J.F. (editor), 1993, MCNP - A General Monte Carlo N-Particle Transport Code, Version 4A, LA-12625, Los Alamos National Laboratory, Los Alamos, N.M.

Eckerman, K.F., and J.C. Ryman, 1993, External Exposure to Radionuclides in Air, Water, and Soil, Exposure to Dose Coefficients for General Application, Based on the 1987 Federal Radiation Protection Guidance, EPA 402-R-93-081, Federal Guidance Report No. 12, prepared by Oak Ridge National Laboratory, Oak Ridge, Tenn., for U.S. Environmental Protection Agency, Office of Radiation and Indoor Air, Washington, D.C.

International Commission on Radiological Protection, 1983, Radionuclide Transformations: Energy and Intensity of Emission, ICRP Publication 38, Annals of the ICRP, Vols. 11-13, Pergamon Press, New York, N.Y.

Kamboj, S., et al., 1998, External Exposure Model Used in the RESRAD Code for Various Geometries of Contaminated Soil, ANL/EAD/TM-84, Argonne National Laboratory, Argonne, Ill.

Kamboj, S., et al., 2000, Probabilistic Dose Analysis Using Parameter Distributions Developed for RESRAD and RESRAD-BUILD Codes, NUREG/CR-6676, ANL/EAD/TM-89, prepared by Argonne National Laboratory, Argonne, Ill., for Division of Risk Analysis and Applications, Office of Nuclear Regulatory Research, U.S. Nuclear Regulatory Commission, Washington, D.C., May.

Thibodeaux, L.J., and S.T. Hwang, 1988, "Landfarming of Petroleum Wastes - Modeling the Air Emission Problem,” Journal of Environmental Progress (1):42.

Yu, C., et al., 1994, RESRAD-BUILD: A Computer Model for Analyzing the Radiological Doses Resulting from the Remediation and Occupancy of Buildings Contaminated with Radioactive Material, ANL/EAD/LD-3, Argonne National Laboratory, Argonne, Ill., Nov.

Yu, C., et al., 2000, Development of Probabilistic RESRAD 6.0 and RESRAD BUILD 3.0 Computer Codes, NUREG/CR-6697, ANL/EAD/TM-98, prepared by Argonne National Laboratory, Argonne, Ill., for Division of Risk Analysis and Applications, Office of Nuclear Regulatory Research, U.S. Nuclear Regulatory Commission, Washington, D.C., Nov. 


\section{APPENDIX}

RESRAD-BUILD INPUT-OUTPUT TEST CASE FILES AND DIAG.OUT AND SUMMARY REPORTS 
The RESRAD-BUILD input-output test case files and diag.out and summary reports for verification are provided in the companion CD-ROM to this document. 
